\title{
The influence of the COVID-19 pandemic on asset-price discovery: Testing the case of Chinese informational asymmetry
}

\author{
Shaen Corbet ${ }^{a, b}$, Yang (Greg) $\mathrm{Hou}^{a *}$, Yang $\mathrm{Hu}^{a *}$, Les Oxley ${ }^{a}$ \\ ${ }^{a}$ School of Accounting, Finance and Economics, University of Waikato, New Zealand \\ ${ }^{b}$ DCU Business School, Dublin City University, Dublin 9, Ireland \\ *Corresponding Authors: yang.hu@waikato.ac.nz (Y.Hu); greg.hou@waikato.ac.nz (G.Hou)
}

\begin{abstract}
The circumstances surrounding the outbreak of the COVID-19 pandemic have generated substantial international political strain as governments attempt to mitigate the widespread associated social and economic repercussions. One theory has focused on the potential for Chinese informational asymmetry. Using Chinese financial market data, we attempt to establish the scale and direction of information flows during multiple distinct phases of the development of the pandemic. Two specific results are identified. Firstly, the majority of domestically-traded Chinese stocks present evidence of significant information flows at a far earlier stage than internationally-traded comparatives, suggesting that domestic investors recognised the dangers associated with COVID-19 far in advance of the rest of the world. One potential explanation surrounds the view that the severity of domestically-reported Chinese news was not appropriately recognised by international investors. Secondly, while evidence of safe-haven and flight-to-safety behaviour is evident throughout traditional energy and precious metal markets, cryptocurrencies became informationally-synchronised with Chinese equity markets, indicating their use as an investor safe-haven. This is a particularly concerning outcome for international policy-maker and regulatory authorities due to the fragility of these developing markets.
\end{abstract}

Keywords: COVID-19; Coronavirus; China; Price Discovery; Information Asymmetry. 


\section{Introduction}

The identification of COVID-19 instigated a transformational process of news dissemination throughout traditional financial markets. Investors and governments were tasked with a quite unique reactionary spectrum when attempting to quantify the potential implications of the growing pandemic. Should governments under-react, they risked exposing vulnerable populations to the harshest exposure to an unknown entity. Should they over-react, such governments faced an unfortunate backlash in the form of a political response from unappeased voters. Investors faced a similar dilemma when attempting to quantify portfolio risk. What has transpired is a multi-directional and multi-faceted international response that takes the shape of cultural tolerances to exceptional risks, ranging from entire nations entering a phase of 'lock-down,' while some countries decided to 'proceed with caution' and minimise disruption. The economic consequences of the former are far more perilous than that of the latter (Alvarez et al. [2020]). However, one of the key concerns during a period of growing attribution of responsibility in the post-containment phase, is quite simply who knew what, and when?

Growing concern has surrounded the role of Chinese authorities in the potential 'shrouding' of important information, although to date, no evidence of such behaviour has been presented. Two distinct accusations have transpired: 1) COVID-19 was a man-made phenomenon, initially transmitted from a lab in Wuhan; and 2) Chinese government officials did not transmit information to the outside world in a timely manner. Politically-driven motivations are quite possibly one reason for such inflammatory accusations, however, financial market data can help to either support or refute the latter accusation in particular. Chinese investors, observing the growth of the severity of COVID-19 prior to the international outbreak of the pandemic, would most likely have possessed substantive information in comparison to international investors (Chan et al. [2007, 2008]), even considering the role of social media in today's society (Luo et al. [2013], Yu et al. [2013], Chen et al. [2014]). The first case of someone suffering from COVID-19 can be traced back to 17 November according to media reports on unpublished Chinese government data. It was stated that Chinese authorities had identified at least 266 people who had contracted the virus, and the earliest case was identified weeks before authorities announced the emergence of the new virus. Further, the identification of a number of substantiated 'rumours' presents evidence that Chinese citizens were potentially aware of this forthcoming threat, but not of the forthcoming international contagion. The first official identification by international organisations such as the World Heath Organisation 
(WHO), was on the 31 December 2019, with the BBC reporting on 3 January 2020 of a pneumonialike 'mystery virus' with characteristics similar to the SARs (severe acute respiratory syndrome) pandemic of 2002 through 2003. Figure 1 present evidence of the number of countries which have been affected to date and the sharp growth in the number of confirmed cases and deaths as reported by the World Health Organisation (WHO). News dissemination was further muddied through the identification on 20 February of an aggressive strain of H5N1 bird flu has been discovered in Hunan Province.

\section{Insert Figure 1 about here}

There are a number of avenues through which evidence sourced in financial markets can help to eradicate such concerns and opaque rumours. To date a number of substantial effects have been identified with regards to the contagion effects of COVID-19, particularly those evident in gold and cryptocurrency markets (Corbet et al. [2020]); and side-effects relating to name association (Corbet et al. [2020]). Otherwise, related research is quite sparse with the exception of that relating to control and continuity (Kamradt-Scott [2013]; Kamradt-Scott [2015]; Sadique et al. [2007]; Weiss [2012]), the effects of pandemics, as measured through swine flu of 2008/2009 on tourism (Page et al. [2012]), and tracing the conceptual entanglement of financial and biological contagion (Peckham [2013]). In the following research, we focus on three distinct periods of analysis to consider the pre-COVID-19 phase; the China-only-COVID-19 phase; and the international transmission phase of COVID-19, to identify evidence of both contagion effects and price discovery. Financial market responses and behaviour within these three distinct phases presents substantial evidence of knowledge dissemination, even those trades belonging to insiders, which has been supported by the works of Huddart et al. [2001] and Aktas et al. [2008], however, not supported by Chakravarty and Mc-

Connell [1999]. Quite simply, we test whether there existed an earlier phase through which Chinese investors recognised the dangers of COVID-19 in the denoted period of 'rumoured' knowledge superiority in November and December 2019, in advance of the first WHO announcement. Evidence of such, would point to an international failure to recognise local information dissemination in China. Should no evidence be identified, such findings would indicate that Chinese investors were equally caught unaware similar to other international investors. Within our research, we specifically consider the contagion effects and transmission of price discovery between Chinese markets and other 
traditional international asset classes.

Further, a quite unique characteristic of Chinese financial markets allows us to provide robustness of such a methodological structure through the comparison and contrasting of not only when investors first realised the substantive and inherent dangers within the outbreak of the COVID-19 pandemic, but further, the direct differentials through the segregation of investors by type. This is completed through the division of investors into 'domestic' (that is Chinese) and 'foreign' investorgroupings, made possible through the use of Chinese B-shares listings, that are best described as equity share investments in companies based in China that trade in foreign currency on two different Chinese exchanges. On the Shanghai Exchange, B-shares trade in US dollars, while on the Shenzhen Exchange, B-shares trade in Hong Kong dollars. B-shares were initially offered to target investment from foreign investors and are considered an alternative to A-shares which are the standard equity market offering from Chinese corporations. A-shares trade in China's local currency the Renminbi, and are used by domestic Chinese investors. The proper name of B-shares is 'Domestically Listed Foreign Investment Shares', which used to be referred to as 'Renminbi Special Shares.' B-shares were only accessible to foreign investors until February 19, 2001 when the China Securities Regulatory Commission ('CSRC') decided to allow domestic residents to buy and sell B shares on the secondary market. While international investors can trade B-shares, there exists a strict, official foreign ownership limit for China A-shares of 30\%, however once foreign ownership holding reaches $28 \%$, no further foreign purchases are permitted ${ }^{1}$. As a result and in accordance with the 'Foreign Ownership Restrictions and Minimum Foreign Headroom Requirement rule, 'foreigners' cannot invest thereafter. The analysis of A-share and B-share interactions provides an opportunity to separate behavioural transmission and price discovery by domestic and foreign investment interactions.

\section{Insert Figure 2 about here}

To date, to the best of the authors knowledge, no research has focused on such specific questions, through which both the timing and evidence provided could be quite useful in mitigating some of the strained rhetoric that has developed as both economic and social social conditions are strained due

\footnotetext{
${ }^{1}$ We also consider the presence of H-Shares, which are denoted as Chinese companies that are listed on the Hong Kong Stock Exchange and are traded in Hong Kong dollars.
} 
to COVID-19. The political and cultural undertones of multifaceted response are also evident in the extensive attribution of blame that has subsequently followed. While the economic ramifications of this exceptional shock continue to unfold, as evidenced in the recent stock market performance presented in Figure 2, some countries have determined that the development of a rhetoric of blaming China might be best to deal with the negative sentiment that has begun to unfold in the face of 'tremendous' economic uncertainty. Such determination without fact could generate substantial damage to inter-regional relations. US President Donald Trump displayed a broad range of emotional responses to the threat of coronavirus, all evidenced in the political undertones that extended within each statement. First exhibiting a range of statements undermining the threat that the US faced, the US President originally declared the COVID-19 pandemic to not exist, moving quickly to state that everything was 'under control'. On 22 January, he declared on CNBC 'We have it totally under control. It's one person coming in from China, and we have it under control. It's going to be just fine' before stating in a New Hampshire rally that warmer temperatures in April would make it go away. Before re-affirming the safety and strength of US financial markets, the US President then proceeded to downplay the risks before finally acknowledging the severity of the pandemic and declaring a national emergency on 14 March and backtracking on earlier remarks, stating on 17 March 'I felt it was a pandemic long before it was called a pandemic'. The breadth of this emotional response was astonishing for a person in possession of such control. However, on 18 March, the undertones of the US President's response took the form of a somewhat darker line when he tweeted 'I always treated the Chinese Virus very seriously, and have done a very good job from the beginning, including my very early decision to close the 'borders' from China - against the wishes of almost all'. The use of the term 'Chinese Virus' quickly expanded to include 'Wuhan virus' and 'Chinese flu' before further manifestation of daily reiterations that China was the source and future recipient of punishment should further evidence suggest that 'they' knowingly misled the world. For many nations, the cause did not prioritise the need for a solution. The transmission of blame to China demonstrated quite an alarming tactical selection by an international superpower. In one of the most incredible cases observed on 22 April, and widely considered to be a publicity stunt, the US state of Missouri attempted to sue the Chinese government over its handling of the coronavirus which it says has led to severe economic losses.

While the benefits of this research not only attempt to somewhat dispel substantial rumour and sources of geopolitical tensions sourced in political rhetoric, the identification of information flows 
and channels of price discovery sourced within Chinese financial markets are particularly important during periods of extreme financial stress. This is particularly important due to the rather opaque nature of news dissemination through social media buffers and controls. Further considering the economic challenges through which COVID-19 presents for the worldwide economy, there are also a number of specific lessons through which we can learn from recent international crises. It is hoped that the sudden shock sourced in the spread of the coronavirus pandemic could manifest in a particularly severe economic trough, but subsequent U-shaped recovery. However, we must monitor certain aspects of our economy with particular care such as deterioration of liquidity and asset quality, both of which are conducive to further economic deterioration (Donaldson [1992]; Cavallo and Valenzuela [2010]; Corbet [2016]; Corbet and Larkin [2017]), deterioration of financial institutions (Allen and Gale [1998]; Chang and Velasco [2001]; Meegan et al. [2018]), systemic risk (Allen and Carletti [2013]; Gorton and Metrick [2012]; Covitz et al. [2013]; Chang and Chen [2014]), and the maintenance of regulation in the face of financial desperation (Kroszner [1999]; Ahuja et al. [2019]; Barrett et al. [2019]; Barrett et al. [2020])

Our research provides a number of interesting results relating to information shares and price discovery during the period surrounding the initial COVID-19 outbreak. Primarily, we identify that Chinese crude oil, corn and international Bitcoin markets play a leading role in the price discovery processes. Moreover, the dynamic relative information share of the SSEA and SSEB indices significantly changes as domestic contagion of the COVID-19 in mainland China begins at a substantially earlier time period than that of the rest of the world. Evidence suggests that Chinese financial markets were responding to news relating to a 'mystery pneumonia' up to six weeks in advance of the official WHO identification of COVID-19. With respect to the time varying net spillovers of higher moments from the SSEA and SSEB indices to other assets, the SSEA index is an information transmitter to domestic crude oil and corn markets in the short run, whereas it receives information shocks from the US dollar index. Both volatility and skewness spillovers are an information transmitter of the SSEA and to the Bitcoin market, while kurtosis spillovers identify a net transmission in the opposite direction. We find evidence supporting the fact that the short-run informational spillovers significantly change across the various stages of the domestic and global contagion of COVID-19.

Furthermore, we detect large variations in the movements of the information share and higher moments' spillovers around two critical dates after which domestic and global COVID-19 outbreaks 
respectively occur. The result reflect the responses of investors to the progression of COVID-19. In addition, the Chinese A-share market has a more important informational role for the crude oil price in China in the short run, whereas the Chinese B-share market has a more important short-run informational role in the foreign exchange market. These roles are intensified as COVID-19 becomes globally contagious and severe. Such evidence suggests two important results. First, the majority of Chinese-traded financial markets occur in the SSEA which shows evidence of an increased informational response across a number of moments at a much earlier stage when compared to the more internationally-traded SSEB. This suggests that financial markets in China recognised the dangers associated with COVID-19 in advance of the rest of the world, a result that does not suggest government collusion such as that identified by other international governments, but rather that local news in China did not filter through to international broadcasters and that international investors did not identify COVID-19 in its infancy. Secondly, while evidence of safe-haven and flight-to-safety behaviour is evident across traditional energy and precious metal markets such as Chinese oil and gold markets, results suggest that cryptocurrencies offered another platform through which wealth was stored during periods of extreme financial market volatility. This result supports the growing literature that has identified potential safe-haven properties in cryptocurrency during the extreme pandemic-related financial market stress (Conlon et al. [2020], Corbet et al. [2020], Yarovaya et al. [2020], Corbet et al. [2020]). This latter result, while supporting the views of cryptocurrency enthusiasts, will be of particular concern to policy-makers and regulators due to the large number of fundamental flaws that exist within these relatively juvenile financial products (Griffin and Shams [2018], Corbet et al. [2018, 2020], Corbet and Cumming [2020], Gandal et al. [2018]). One particular explanation for this outcome could be due to the education schemes that have been developed and progressed by the Chinese Communist Party aimed at educating the population of China about the nature and future of digital currencies ${ }^{2}$.

The paper is structured as follows: previous literature that guide the selection of areas of interest pursued in the paper, are summarised in Section 2. Section 3 presents a thorough explanation of the data used in this analyses, while Section 4 presents a concise overview of the methodologies utilised to analyse the hypotheses to be evaluated. Section 5 specifically investigates the interactions between Chinese financial markets and other traditional financial market asset classes, while Section

\footnotetext{
${ }^{2}$ An example of such material is available here
} 
6 concludes.

\section{Previous Literature}

Chinese financial markets have received growing attention due to a number of unique characteristics they display, particularly the existence of A-share and B-share exchanges in both Shanghai and Shenzhen. Chakravarty et al. [1998] found that Chinese foreign class B-shares trade at an average discount of approximately $60 \%$ compared to the prices at which domestic A-shares trade, which seems to be caused by an information asymmetry where foreign investors have less information on Chinese stocks than domestic investors. Chui and Kwok [1998] further argues that correlations between A- and B-shares are consistent with the same notion of information asymmetry, which is likely due to informational barriers that are present in China. Schuppli and Bohl [2010] found that foreign institutions presented a stabilising effect on the Chinese stock markets and contributed to improved market efficiency, a factor which Wang et al. [2010] identified as the cause of declining cross-correlations over time. Yuan et al. [2012] found the same cross-correlation to be multi-fractal, and both Los and Yu [2008] and Wang and Iorio [2007] argued this provided evidence of gradual integration. Chen et al. [2001] suggested that initial price differentials relating to B-shares was likely attributable to illiquidity, while Fung et al. [2000] found that weak correlations suggest that both the A- and B-shares markets reflect different fundamental drivers. Mei et al. [2009] found that trading caused by investors' speculative motives can help explain a significant fraction of the price difference between Chinese dual-class shares, while Chan et al. [2007] identified evidence of shifting informational patterns due to regulatory changes in February 2001, however A-shares continued to dominate the price discovery process.

Cai et al. [2011] found that weakening informational asymmetries underlie much of the change in the markets' relative pricing, where policy and corporate governance change appears to be the principal force driving the efficiency gains, while Meng et al. [2020] identified, through the use of A-share data, the presence of a negative information effect from short-selling restrictions. Xianghai [1996] identified cross-sectional differences between the prices of both A- and B-shares, with evidence suggesting the presence of a correlation with investors' attitudes toward risk. Further, Tan et al. [2008] and Yao et al. [2014] examined herding behaviour in dual-listed A-share and B-share stocks, identifying evidence of herding within both the Shanghai and Shenzhen A-share markets and also within both B-share markets. Herding by A-share investors in the Shanghai market is found to 
be more pronounced under conditions of rising markets, high trading volume, and high volatility, while no asymmetry is apparent in the B-share market. Further evidence suggests that herding is more prevalent at the industry-level, stronger for the largest and smallest stocks, and is stronger for growth stocks relative to value stocks, while evidence suggests that this diminishes over time. Wang and Jiang [2004] found that B-shares retain significant exposure to their domestic market and therefore provide foreign investors with diversification opportunities, while Lin and Tsai [2019] found evidence supporting the usage of B-shares as a hedging tool for the Shanghai housing market, to which no benefits were identified through the use of A-shares.

When considering specific Chinese financial market effects, Eun and Huang [2007], and in the early 1990s Bailey [1994], found that Chinese investors are willing to pay a significant premium for more liquid stocks or for dividend-paying stocks, while investors value local A-shares more if there are offshore counterparts, implying that a Chinese firm with a foreign shareholder base has a lower cost of capital. Qiao and Dam [2020] analysed the Chinese overnight return puzzle, finding empirical support that the $T+1$ induced discount is estimated to be $14 \mathrm{bps}$, and that the $T+1$ discount contributes significantly to overnight risk. Lan et al. [2020] examined whether and how the market interacts with investor sentiment in the context of seasoned equity offerings (SEOs) by Chinese listed firms, to find robust evidence that investor sentiment drives the pre-announcement abnormal return. In the post-announcement period, the market corrects the sentiment-driven overvaluation within approximately one month. Qi et al. [2000] found that the ownership structure composition and relative dominance by various classes of shareholders can affect the performance of stateowned enterprise (SOE)-transformed and listed firms. While investigating the impacts of securities supervision and the law-enforcing regulations upon stock pricing efficiency, He and Fang [2019] found that the pricing efficiency of the sanctioned companies is significantly lower than that of non-offending companies; therefore the administrative supervision and law-enforcing regulations of China's regulatory authorities do not promote pricing efficiency in the stock market.

The transmission of market sentiment through the form of price discovery and information flows can provide substantial signals as to the presence of particular accumulation of pressure, market discontinuity, and indeed, warnings of forthcoming deterioration of financial conditions as traders seek shelter. Hasbrouck [2002] presented an overview of the econometric approaches available to characterise the random-walk component in single- and multiple-price settings, while De Jong [2002] presented clarification of the relationship between the information share and the common factor 
component weight. Yan and Zivot [2010a] found that the information share can provide information on the relative informativeness of individual markets.

When applying such price discovery techniques to financial market data, Su and Chong [2007] studied the price-discovery process for a number of Chinese cross-listed stocks to find that Hong Kong-based stocks are cointegrated, mutually adjusting and contributing more to stocks cross-listed on the New York Stock Exchange. Such information flows have been analysed within commodity markets such as oil and gold (Zhang and Wei [2010]) where oil prices are found to Granger-cause and contribute to the volatility of gold, and geographical regions such as US and Canadian cross-listings (Chen and Choi [2012], Frijns et al. [2015], Australia and New Zealand (Frijns et al. [2010]), the US and Spain (Pascual et al. [2006]), the US and Germany (Grammig et al. [2005]), cross-listing within the US (Harris et al. [2002a]), and sequentially across the world (Wang and Yang [2011]). Another significant area involves the interlinkages between spot markets and derivatives products such as futures and options markets. Within this context, spot prices were found to provide more price discovery when considering foreign exchange futures from the Chicago Mercantile Exchange (Chen and Gau [2010a]). Muravyev et al. [2013] and Fricke and Menkhoff [2011] found no evidence of price discovery when considering US equity options and their spot counterparts using tick-by-tick data during periods of market disagreement, and German Bond futures respectively. Whereas, while accounting for transaction costs, Theissen [2012] find evidence that DAX futures lead price discovery to comparative spot markets, while Lin et al. [2018] find similar evidence in the market for US ETFs, however, the effect is found to diminish during high-sentiment periods as informed traders become less willing to leverage their information advantages on the futures market. Chen and Tsai [2017] and Choy and Zhang [2010] found that futures markets also led the price discovery relationship in both the VIX and Hong Kong regular and mini futures markets' effects on their respective spot markets. Further, Anand et al. [2011] identified the role of geographic influence, while Nimalendran and Ray [2014] showed that algorithmic trades for less liquid stocks are correlated with higher spreads and price impact, as well as contemporaneous trading on the lit venues. In recent research relating to rapidly growing cryptocurrency markets, price discovery and information flows have been analysed using Bitcoin (Brandvold et al. [2015], Corbet et al. [2018], Katsiampa et al. [2019a]; Katsiampa et al. [2019b]; Akyildirim et al. [2019]) where Mt.Gox and BTC-e were identified to be market leaders with the highest information share and Bitcoin futures dominate price discovery relative to spot markets. 


\section{Data}

We collect high-frequency market data, at 30-minute intervals, for the purpose of this analysis, including the Shanghai Stock Exchange A-share index (SSEA index), the Shanghai Stock Exchange B-share index (SSEB index), the Chinese crude oil commodity futures (traded on the Shanghai International Energy Exchange), Chinese corn commodity futures (traded on the Dalian Commodity Exchange), Bitcoin spot prices (which trade on the Bitstamp cryptocurrency trading exchange) and the US dollar currency index. It should be noted that the Chinese crude oil futures contracts were firstly introduced on 26 March, 2018 and they were the first futures contract in the Chinese mainland open to overseas investors. The underlying spot asset for oil futures contract is medium sour crude oil which is one major crude oil product imported by China and most heavily utilised to support economic development. The SSEA index comprises the A-share stocks traded in the Shanghai Stock Exchange while the SSEB index consists of all the B-share stocks traded in the same exchange. Both A-share and B-share stocks are available for domestic investors to trade; however, foreign investors are allowed to trade B-share stocks only. Normally, overseas investors are prohibited from access to trading A-share stocks in China. The selection of data from the Bitstamp cryptocurrency trading exchange is based on the fact that it is one of the largest and longest trading platforms of cryptocurrencies in the world. Prices of Bitcoin traded on that platform are deemed representative of the global performance of Bitcoin . All the data are collected from Thomson Reuters Datascope and Thomson Reuters Eikon.

The sample period for data collection is 1 July 2019 through to 10 April 2020, which includes three distinct stages of the COVID-19 outbreak. The first sub-period runs from 1 July 2019 through 16 November 2019. This selection is made due to the media identification on the 17 November 2019 of the first case of COVID-19 detected in mainland China, reported by the South China Morning Post. Hence, this sub-period is the first stage without the latent impacts of COVID-19 and hereafter labelled as (P1). The second sub-period is from 17 November 2019 through to 30 December 2019. On the 30 December 2019, as reported by World Health Organisation (WHO), the Wuhan Municipal Health Commission in China reported a cluster of cases of pneumonia in Wuhan, Hubei Province. The novel coronavirus, in its current form was subsequently identified and announced to the world as a global pandemic. After this date, COVID-19 was gradually acknowledged globally and its impacts became internationally contagious. Hence, we identify the second sub-period (P2) as a stage where the COVID-19 affects only domestic China. The third sub-period (P3) runs from 31 
December 2019 to 10 April 2020 and is the final stage of analysis, where COVID-19 subsequently spreads from China and starts a widespread contagious period to the rest of the world.

We match prices of the SSEA or SSEB index with those of oil futures, corn futures, Bitcoin and US dollar currency index. High-frequency data during overlapped trading times are chosen to create the samples and any data point that falls outside the overlapped trading frame is excluded. Henceforth there are four samples of SSEA-Oil, SSEA-Corn, SSEA-Bitcoin and SSEA-USD, as well as SSEB-Oil, SSEB-Corn, SSEB-Bitcoin and SSEB-USD via which each pair is analysed in detail. With these samples, we investigate both long-term price discovery and short-run information transmission of higher moments from either the SSEA or SSEB index to the other assets. From our discussion above, we may expect to see different results associated with the A-share index from those of the B-shares, which would help shed light on the different responses of stock markets in China to the COVID-19 outbreak. Table 1 presents descriptive statistics of return series for the SSEA index, SSEB index, oil futures, corn futures, Bitcoin and US dollar currency index. We should note that returns are calculated by taking the first differences of logarithmic prices. Results for the full sample period as well as the three sub-periods (P1, P2 and P3) are presented. As can be observed in Table 1, across the whole sample period, the mean returns of SSEA, SSEB, oil and Bitcoin are negative while the mean returns for the US dollar index and corn are positive. This presents evidence of a bear market for stock markets, oil and Bitcoin markets while a more bullish, upward-trending market for US foreign exchange and corn markets, across the whole timeline of the COVID-19 outbreak. The volatility of Bitcoin is the largest, followed by that of oil. The volatility levels of SSEA, SSEB, US dollar index and corn are quite low in comparison. For all of the assets under observation, the Jarque-Bera normality test rejects the hypothesis that return series follow a normal distribution. Non-zero skewness and excess kurtosis are observed for all the assets.

\section{Insert Table 1 about here}

Furthermore, the mean returns for both SSEA and SSEB indices remain negative in the three sub-periods with one exception, SSEA during P2, where its mean return is positive. This particular result suggests that when COVID-19 spread across mainland China, before it was officially announced as contagious to the rest of the world, the Chinese A-share market experienced a sharp increase in value. When looking at the performance of the commodity oil and corn futures in 
China, the mean returns for oil are positive during P1 and P2, however, in the same periods, the corn market presents negative mean returns. When it comes to P3, the oil market has negative mean returns which are large in size. In contrast, the corn market undergoes an increase in value. It seems when the COVID-19 became an international concern, crude oil prices in China were significantly affected. Turning to Bitcoin, its mean return remains negative across the three sub-periods and its value falls significantly during the P2. The US dollar currency index experiences increase in values during both $\mathrm{P} 1$ and $\mathrm{P} 3$, whereas its mean return is negative during $\mathrm{P} 2$.

\section{Insert Figure 3 about here}

Figure 3 shows how the price series, at 30-min intervals, change across the time-periods analysed. Two interesting observations are noteworthy. First, the price series for the SSEA index moves in tandem with that of oil, Bitcoin, corn and US dollar index. A similar observation is found for price movements for the SSEB index. It would seem sensible at this stage, therefore, to test whether there exists a long-run equilibrium relationship between the stock indices and other assets, i.e., are the stock indices and other assets cointegrated? Second, there is a substantial decrease in prices during the P3 followed by substantial oscillations in price towards the end of sample period. This observation corresponds with a series of intensive measures and policies made by the Chinese government to mitigate the development of the COVID-19 pandemic, including the lock-down of Wuhan city and Hubei province on 23 January 2020 and the sequential lock-downs across the whole country thereafter. We test the stationarity of all of the logarithmic prices by using the traditional $\mathrm{ADF}$ and $\mathrm{PP}$ tests where the results indicate that all the prices are integrated of order one, or I(1). We therefore employ the Johansen cointegration test to examine whether either the SSEA series is cointegrated with each series of oil, corn, Bitcoin or US dollar currency index and then the same using SSEB. Our results show that both the SSEA and SSEB price series are cointegrated with those of oil, corn, Bitcoin and US dollar currency index in each paired sample during the whole sample period. This indicates that there exists a long-run equilibrium between the stock indices and alternative asset in each paired sample. Their prices are found to be driven by a common efficient price and information share measure which will be calculated to evaluate the price discovery performance in the long run. 


\section{Methodology}

\subsection{Information share measures}

To investigate information shares between the selected markets, we first let $Y_{t}$ be a $2 x 1$ vector of price series of two markets integrated as $\mathrm{I}(1)$. If the two price series are cointegrated at order zero, which means $Y_{t}$ contains one single common stochastic trend, then $Y_{t}$ can be specified in the following bivariate vector error correction model (Engle and Granger [1987]):

$$
\Delta Y_{t}=\Pi Y_{t-1}+\sum_{i=1}^{k} A_{i} \Delta Y_{t-i}+\varepsilon_{t}
$$

where $\Pi=\alpha \beta^{t}$. Both $\alpha=\left[\alpha_{1}, \alpha_{2}\right]^{\prime}$ and $\beta=[1,-\beta]^{\prime}$ are both $2 x 1$ vectors. $\alpha_{1}$ and $\alpha_{2}$ are the error correction coefficients, measuring responses of two markets to deviations of the past long-run equilibrium. $\beta$ is the cointegrating coefficient, while $\Delta$ is the first-order difference operator. $\varepsilon_{t}$ is a vector of innovations, where the lag order $k$ is chosen by Akaike Information Criteria (AIC). According to Hasbrouck [1995], Eq.1 can be rearranged into the following vector moving average (VMA) model:

$$
Y_{t}=Y_{0}+\Psi(1) \sum_{s=1}^{t} \varepsilon_{s}+\Psi *(L) \varepsilon_{t}
$$

where $\Psi(1) \varepsilon_{t}$ represents the long run impact of innovations on the price series. If we let $\Psi(1)$ and $\Psi(2)$ be each row of $\Psi(1)$ in Eq.2, following Hasbrouck [1995], $\Psi(1)=\Psi(2)$, which is determined by the cointegrating coefficient $\beta$ equal to one. $\Psi(1)(\Psi(2)) \varepsilon_{t}$, represents the long-run impacts of innovations on the first (second) price series. If we let Let $\Omega$ be the covariance matrix of $\varepsilon_{t}$ and $\Psi$ denote either $\Psi(1)$ or $\Psi(2)$. Given a general case where $\Omega$ is not diagonal, the Information Share (IS) of market $\mathrm{j}(\mathrm{j}=1,2)$ is given by Hasbrouck [1995] as:

$$
S_{j}=\frac{\left([\Psi F]_{j}\right)^{2}}{\Psi \Omega \Psi^{\prime}}
$$

where $\mathrm{F}$ is the Cholesky factorisation of $\Omega$ such that $\Omega=F F^{\prime} .[\Psi F]_{j}$ is the jth element of the vector $\Psi F$. Due to the order of price series $\mathrm{j}$ in $Y_{t}$ in the process of Cholesky factorisation, the upper (lower) bound of series j's information share arises if series $\mathrm{j}$ is the first (last) variable in $Y_{t}$. It has been widely adopted in the literature that IS of market $\mathrm{j}$ can be represented by a mid-point 
of IS upper and lower bounds (see, for example Baillie et al. [2002]; Booth et al. [2002]; Chen and Gau [2010b]; Putniňs [2013], among others). Following the literature, we calculate two bounds of IS for each market and take the simple average as a result of information share. The IS of market $\mathrm{j}$ is the contribution of market $\mathrm{j}$ to the total variance of the common efficient price or permanent impact (Baillie et al. [2002]; Lien and Shrestha [2014]). Yan and Zivot [2010b] further suggest that IS measures a combination of relative level of noise and relative leadership in reflecting innovations in the fundamental value (Putniňš [2013]). Gonzalo and Granger [1995] propose that the two price series in $Y_{t}$, if cointegrated, can be decomposed into the following form:

$$
Y_{t}=A f_{t}+\tilde{Y}_{t}
$$

where $Y_{t}$ is comprised of one permanent component $f_{t}$ and one transitory component $\tilde{Y}_{t} . f_{t}$ is a so-called common factor that is a non-stationary series while $\tilde{Y}_{t}$ is stationary. Two assumptions underlying the validation of Eq.(4) are (i). $f_{t}$ is a linear function of the series in $\tilde{Y}_{t}$; (ii). $\tilde{Y}_{t}$ does not Granger cause $f_{t}$ in the long run. In other words, the justification of Eq.4 requires:

$$
f_{t}=\theta^{\prime} Y_{t}
$$

where $\theta$ is the $2 x 1$ permanent component coefficient vector. It should be noted that the dimension of the permanent component is one since cointegration suggests one common stochastic trend in $Y_{t}$. Booth et al. [1999, 2002] and Harris et al. [2002b] develop normalised coefficients in $\theta^{\prime}$ that convey information with respect to contributions to the common factor made by the original non-stationary series in $Y_{t}$. Such information is interpreted as the contribution of the series to the price discovery process. Let $\theta=\left[\theta_{1}, \theta_{2}\right]^{\prime}$ and $\theta$ is orthogonal to $\alpha$ in Eq.1 Then we can have component share (CS) as follows

$$
\theta_{1}=\frac{\alpha_{2}}{\alpha_{2}-\alpha_{1}}, \quad \theta_{2}=1-\theta_{1}
$$

where $\theta_{1}$ is the component share of the first series in $Y_{t}$ and $\theta_{2}$ is the component share of the second series in $Y_{t}$. Yan and Zivot [2010b] interpret CS as the level of noise in one price series relative to the other.

Yan and Zivot [2010b] further reveal that, given a case of two price series in $Y_{t}$, the resulting 
CS is a function of the dynamic responses of the two series to transitory shocks only, whereby transitory shocks are represented by noise due to trading frictions. Meanwhile, IS is a function of the dynamic response of the two series to both transitory and permanent shocks and permanent shocks are denoted by innovations in the fundamental values. In this case, IS and CS may give misleading information regarding price discovery in some situations due to their dependence on the dynamic response to transitory shocks (Putniņ̌s [2013]). To circumvent this problem, Yan and Zivot [2010b] propose the information leadership share (ILS) to generate cleaner contribution of the series to the price discovery process as follows:

$$
I L_{1}=\left|\frac{I S_{1}}{I S_{2}} \frac{C S_{2}}{C S_{1}}\right|, \quad I L_{2}=\left|\frac{I S_{2}}{I S_{1}} \frac{C S_{1}}{C S_{2}}\right|
$$

where $I S_{1}$ and $I S_{2}$ are the mid-points of information share of the two price series in $Y_{t}$ while $C S_{1}$ and $C S_{2}$ are component share of the two price series in $Y_{t}$. Putniňš [2013] proposes normalised metrics based on Eq.7 so that the range of ILS can be controlled between 0 and 1 . Hence, we have the following:

$$
I L S_{1}=\frac{I L_{1}}{I L_{1}+I L_{2}}, \quad I L S_{2}=\frac{I L_{2}}{I L_{1}+I L_{2}}
$$

As can be seen from the equation above, ILS is a combination of CS and IS so that the impact from dynamic responses to transitory shocks is cancelled out and a clean measure of relative informational leadership is achieved.

In this paper, not only do we offer traditional static CS, IS and ILS measures, we also consider time variations of these metrics. The way to obtain time varying CS, IS and ILS measures is as follows. First, we obtain time varying error correction coefficients in the vector $\alpha$ of Eq.1 through applying a rolling window procedure to the full sample of the data ${ }^{3}$. Then the time varying coefficients are used to calculate time varying CS, IS and ILS measures. Second, the variance and covariance of innovations in the matrix $\Omega$ of Eq.3 are replaced by the conditional time series of the variance and covariance which are obtained from a two-state regime switching model. This model will be illustrated in detail in the next section. In our procedure the error correction coefficients

\footnotetext{
${ }^{3}$ The window size is normally set to be 100 and the step size is 1 . In case where the lag order k of Eq.1 is large enough, a larger window size might be used.
} 
and the variance-covariance matrix of innovations which carry key information of information share measures, are both modelled to be time-dependent. Moreover, to present a clearer picture of the role of stock index relative to another type of asset including commodities, Bitcoin or the US dollar currency index in the long-run price discovery process, we calculate logarithmic ratios of the information share measures as follows:

$$
\text { CS ratio }=\log \left(\frac{C S_{s}}{C S_{c}}\right), \quad I S \text { ratio }=\log \left(\frac{I S_{s}}{I S_{c}}\right), \quad I L S \text { ratio }=\log \left(\frac{I L S_{s}}{I L S_{c}}\right)
$$

where $\log ($.$) denotes the natural logarithm. C S_{s}$ and $C S_{c}$ are the component share of the stock index and counterpart asset, respectively. $I S_{s}$ and $I S_{c}$ are mid-points of the information share of the stock index and counterpart asset, respectively. $I L S_{s}$ and $I L S_{c}$ are information leadership share of the stock index and counterpart asset, respectively. Note that a positive log ratio suggests that the stock index dominates in the long-run price discovery process while a negative value suggests the counterpart asset dominates in the long-run price discovery process. We also calculate time varying ratios by using time varying CS, IS and ILS in Eq.9.

\subsection{Two-state regime switching model}

Next, we employ a two-state regime switching model developed by Chan et al. [2018] to specify a conditional series for the variance, skewness and kurtosis for stock indices, commodities, Bitcoin and the US dollar currency index. As stated by Chan et al. [2018], a salient feature of this model is that it considers two regimes of market status, that is, high return-low volatility in the bull state and low return-high volatility in the bear state. A bivariate two-state regime switching model is shown as

$$
\begin{gathered}
r_{t}=u_{i t}+\varepsilon_{i t} \\
u_{i t}=E\left(r_{t} \mid s_{t}=i, F_{t-1}\right) \\
\varepsilon_{i t} \mid F_{t-1} \sim N\left(0, H_{i t}\right)
\end{gathered}
$$

where $r_{t}=\left(r_{t}^{s}, r_{t}^{c}\right)^{\prime}$ is a vector of return series of one stock index and one other asset including 
commodities, Bitcoin or the US dollar currency index at time t. $r_{t}^{s}$ represents the stock index return while $r_{t}^{c}$ denotes the counterpart asset return. $s_{t}$ represents the unobserved regime at time t. $s_{t}=1$ indicates regime 1 at time t while $s_{t}=2$ indicates regime 2 at time t. $u_{i t}=\left(u_{i t}^{s}, u_{i t}^{c}\right)^{\prime}$ is a vector of conditional means of return series at regime i, dependant on the past information up to time t- 1 , that is, $F_{t-1} . F_{t-1}$ contains the past information with respect to the bivariate distribution of $r_{t}^{s}$ and $r_{t}^{c}$ at either state. Note that any information on $s_{t}$, lagged $s_{t}$ or their probabilities is excluded from $F_{t-1} . \varepsilon_{i t}=\left(\varepsilon_{i t}^{s}, \varepsilon_{i t}^{c}\right)^{\prime}$ is a vector of innovations at regime i. $H_{i t}$ is a conditional variance-covariance matrix of $r_{t}$ at regime i. $\varepsilon_{i t}$ is assumed to follow a bivariate normal distribution under each regime. Further, the conditional means of $r_{t}$ at regime i are specified in a Vector Autoregressive (VAR) model as below:

$$
\begin{aligned}
& r_{t}^{s}=u_{i}^{s}+a_{i}^{s} r_{t-1}^{s}+b_{i}^{s} r_{t-1}^{c}+\varepsilon_{i t}^{s} \\
& r_{t}^{c}=u_{i}^{c}+a_{i}^{c} r_{t-1}^{s}+b_{i}^{c} r_{t-1}^{c}+\varepsilon_{i t}^{c}
\end{aligned}
$$

where $\mathrm{i}=1,2 . u_{i}^{s}$ and $u_{i}^{c}$ are the unconditional means of $r_{t}^{s}$ and $r_{t}^{c}$ at regime i. $a_{i}^{s}$ and $b_{i}^{s}\left(a_{i}^{c}\right.$ and $b_{i}^{c}$ ) measure the effects of the lagged values of $r_{t}^{s}$ and $r_{t}^{c}$ on current $r_{t}^{s}\left(r_{t}^{c}\right)$. In Eq.13, the lag order of VAR is chosen to be 1 according to Akaike Information Criteria (AIC). Following Chan et al. [2018], $H_{i t}$ in Eq.(10) is specified as:

$$
H_{i t}=D_{i t} R_{i t} D_{i t}, D_{i t}=\left[\begin{array}{cc}
\sqrt{h_{i t}^{s}} & 0 \\
0 & \sqrt{h_{i t}^{c}}
\end{array}\right] \quad R_{i t}=\left[\begin{array}{cc}
\rho_{i} & 1 \\
1 & \rho_{i}
\end{array}\right] \quad i \epsilon 1,2
$$

where $h_{i t}^{s}$ and $h_{i t}^{c}$ are the variances of $r_{t}^{s}$ and $r_{t}^{c}$ at regime i, respectively. $\rho_{i}$ is the regimedependant correlation between oil and Bitcoin returns at regime i. Further, to take into account the effects of the COVID-19 outbreak on volatility levels, $h_{i t}^{s}$ and $h_{i t}^{c}$ are specified ${ }^{4}$ as:

$$
h_{i t}^{s}=h_{i}^{s}+\gamma_{i, 1}^{s} d_{2 t}+\gamma_{i, 2}^{s} d_{3 t}
$$

\footnotetext{
${ }^{4}$ We also consider specifying the variances and correlations in Eq.14 by a bivariate GARCH framework. However, doing so yields nuisance parameters which do not improve the performance of the model given lower total loglikelihood and higher information criteria. It also incurs hardship of convergence in the MLE procedure. Hence we stick to specifications in Eqs. 14 and 15 for variances and correlations at two regimes.
} 


$$
h_{i t}^{c}=h_{i}^{c}+\gamma_{i, 1}^{c} d_{2 t}+\gamma_{i, 2}^{c} d_{3 t}
$$

where $d_{2 t}$ is a dummy variable taking a value of 1 when the sample period is between 17 November 2019 and 30 December 2019 and zero otherwise. $d_{3 t}$ is a dummy variable taking a value of 1 when the sample period is between 31 December 2019 and 10 April 2020 and zero otherwise. $\gamma_{i, 1}^{s}$ $\left(\gamma_{i, 1}^{c}\right)$ measures whether the outbreak of the COVID-19 in mainland China affects $h_{i t}^{s}\left(h_{i t}^{s}\right)$ locally. $\gamma_{i, 2}^{s}\left(\gamma_{i, 2}^{c}\right)$ examines whether the outbreak of the COVID-19 affects $h_{i t}^{s}\left(h_{i t}^{c}\right)$ when the virus becomes internationally contagious. In the context of a two-state regime switching model, we specify the transition probabilities between two regimes to be time-dependent. This is because substantial flexibility can be obtained by allowing for time varying transition probabilities compared to the static ones (Gray [1996]; Chan et al. [2018]). The transition probabilities are specified as:

$$
\begin{gathered}
\operatorname{Pr}\left(s_{t}=j \mid s_{t-1}=i, F_{t-1}\right)=p_{i j, t}, i, j \in 1,2 \\
0 \leq p_{i j, t} \leq 1 \\
\sum_{j=1}^{2} p_{i j, t}=1 \text { for all } i
\end{gathered}
$$

and $p_{i j, t}$ is specified to be a simple function of time trend as follows:

$$
p_{i i, t}=\operatorname{Pr}\left(S_{t}=i \mid S_{t-1}=i, F_{t-1}\right)=\Phi\left(a_{i}+b_{i} \text { trend }\right)
$$

where $\mathrm{i}=1,2$. trend is the time trend. $\Phi($.$) is the cumulative normal distribution function,$ which ensures that $0<p_{i i, t}<1$. Our choice to use the time trend as an instrumental variable for conditioning transition probabilities that govern the regime switching process aligns with Chan et al. [2018] who propose that specifying time variations of transition probabilities improves model performance ${ }^{5}$. The model estimates of the two-state regime switching model of Eqs. 18 through 21

\footnotetext{
${ }^{5}$ We also tried alternative variables such as lagged returns or differentials in lagged returns as the instrumental variable for transition probabilities. However, model performance is inferior to the case of using time trend due to hardship in convergence, lower log-likelihood and higher information criteria. Hence, we stick to time trend as the instrumental variable for transition probabilities.
} 
are obtained by a quasi-maximum likelihood estimation (QMLE). Based on the estimation results, we follow Chan et al. [2018] to compute the conditional series of variance, skewness and kurtosis of return series of $r_{t}^{s}$ and $r_{t}^{c 2}$. Based on these calculated conditional higher moments' series we specify informational spillovers of variance, skewness and kurtosis in the next section.

\subsection{Spillovers of higher moments}

Finally, we employ an extended VAR(1) methodology to examine the spillovers of variance, skewness and kurtosis between the stock index and one alternative type of asset including commodities, Bitcoin or the US dollar currency index. This model is analogous to the GARCH-family of models used to examine volatility spillovers in the literature (see, for example Chan and Chen [1991]; Iihara et al. [1996]; Tse [1999]; Del Brio et al. [2017]; among others). It also aligns with the work of Del Brio et al. [2017] with respect to the specification of skewness and kurtosis spillovers. The model is shown as follows:

$$
\begin{gathered}
\mathrm{HMS}_{s, t}=\delta_{0}+\delta_{1} \eta_{s, t-1}+\delta_{2} \mathrm{HMS}_{s, t-1}+\delta_{3} \mathrm{HMS}_{c, t-1} \\
\mathrm{HMS}_{c, t}=\phi_{0}+\delta_{1} \phi_{c, t-1}+\phi_{2} \mathrm{HMS}_{c, t-1}+\phi_{3} \mathrm{HMS}_{s, t-1}
\end{gathered}
$$

where $\mathrm{HMS}_{s, t}$ and $\mathrm{HMS}_{c, t}$ are conditional series of variance, skewness or kurtosis for the stock index and counterpart asset returns that are obtained from Section 3.2, respectively. $\eta_{s, t-1}\left(\eta_{c, t-1}\right)$ is the information shocks of higher moments at time $t-1$ for the stock index (counterpart asset) returns. For variance spillovers, $\eta_{k, t-1}=\left(\sum_{i=1}^{2} p_{i t} \epsilon_{i, t-1}^{k}\right)^{2}$ where k denotes s (stock index) or c (counterpart asset) and $p_{i t}$ is the probability of regime $\mathrm{i}(\mathrm{i}=1,2)$ at time t. $\epsilon_{i, t-1}^{k}=\frac{\varepsilon_{i, t-1}^{k}}{\sqrt{h_{i t}^{k}}}$ where $\varepsilon_{i, t-1}^{k}$ is the lagged residuals at regime $\mathrm{i}(\mathrm{i}=1,2)$ from Eq.10. For skewness and kurtosis spillovers, $\eta_{k, t-1}=\left(\sum_{i=1}^{2} p_{i t} \epsilon_{i, t-1}^{k}\right)^{3}$ and $\eta_{k, t-1}=\left(\sum_{i=1}^{2} p_{i t} \epsilon_{i, t-1}^{k}\right)^{4}$ respectively. $\delta_{3}$ and $\phi_{3}$ measure the spillover effects from counterpart asset to stock index and the vice versa, respectively. Furthermore, we are interested in the spillover effects across difference stages of the COVID-19 outbreak. Then we extend Eq.22 to have the following forms:

$$
\mathrm{HMS}_{s, t}=\delta_{0}+\delta_{1} \eta_{s, t-1}+\delta_{2} \mathrm{HMS}_{s, t-1}+\delta_{3,1} d_{1, t} \mathrm{HMS}_{c, t-1}+\delta_{3,2} d_{2, t} \mathrm{HMS}_{c, t-1}+\delta_{3,3} d_{3, t} \mathrm{HMS}_{c, t-1}
$$


$\mathrm{HMS}_{c, t}=\phi \delta_{0}+\phi_{1} \eta_{c, t-1}+\phi_{2} \mathrm{HMS}_{c, t-1}+\phi_{3,1} d_{1, t} \mathrm{HMS}_{s, t-1}+\phi_{3,2} d_{2, t} \mathrm{HMS}_{s, t-1}+\phi_{3,3} d_{3, t} \mathrm{HMS}_{s, t-1}$

where $d_{1 t}, d_{2 t}$ and $d_{3 t}$ are dummy variables which are created to track different stages of the COVID-19 outbreak. $d_{1 t}$ takes a value of 1 from July 1, 2019 to November 16, 2019, and zero otherwise and is referred to as P1. As in Section $3.2, d_{2 t}$ is a dummy variable taking a value of 1 between November 17, 2019 and December 30, 2019, and zero otherwise, and referred to as P2. $d_{3 t}$ is a dummy variable taking a value of 1 December 31, 2019 and April 10, 2020, and zero otherwise, referred to as P3. $\delta_{3,1}, \delta_{3,2}$ and $\delta_{3,3}\left(\phi_{3,1}, \phi_{3,2}\right.$ and $\left.\phi_{3,3}\right)$ measure the spillover effects from the counterpart asset to the stock index (from the stock index to counterpart asset) during P1, P2 and P3, respectively. Eq.24 and 25 is used to estimate static spillovers of the higher moments using the full period.

In this paper, we focus on time varying spillovers of higher moments across different stages of the COVID-19 outbreak. In doing so, we apply a rolling-window procedure to Eq.22 and 23 with a window size of 100 observations and step size of 1 observation, where the full sample is utilised in this process. Henceforth we obtain time varying estimated values of coefficients $\delta_{3}$ and $\phi_{3}$ which are important for our analysis. The time varying coefficients are labelled $\delta_{3 t}$ and $\phi_{3 t}$. In addition, we calculate net spillovers of the higher moments running from stock index to the counterpart asset. The static net spillovers are calculated as $\left|\phi_{3}\right|-\left|\delta_{3}\right|$ and the time varying versions are calculated as $\left|\phi_{3 t}\right|-\left|\delta_{3 t}\right|$. The latter helps us reveal time variant patterns of information flow, if they are present, from the stock index to different types of financial assets and foreign exchange across different stages of the COVID-19 outbreak. It should be noted that positive net spillovers indicate the stock index plays a leading role in the short-term information transmission process while a negative value suggests that the counterpart asset plays a leading role in the same process.

\section{Results}

\subsection{Two-state regime switching model}

In Tables 2 and 3, we present the estimation results of the two-state regime switching model. We can see that the current returns for either regime can be significantly affected by lagged effects. More importantly, from the estimation of each paired sample, a state with high volatilities between 
two markets (a bear-state) and a state with low volatilities between two markets (a bull-state) are clearly identified. Both time-periods P2 and P3 present evidence of significant impacts on volatility under both states. Such a result indicates that there exist multiple stages of contagion, or indeed shifting interactions during the COVID-19 pandemic.

\section{Insert Tables 2 and 3 about here}

The pairwise correlations at either regimes 1 or 2 are found significant. It should be noted that some insignificant regime-dependent pairwise correlations would not rule out non-zero regime-free pairwise correlations which are calculated from regime-dependent volatilities of the two markets, probabilities of regimes 1 and 2 and regime-dependent correlations themselves. This is because regime-dependent volatilities are significant and we find probabilities of the two regimes are significantly driven by time. In this sense, regime-free pairwise correlations are significant across

paired samples. Finally, the Hansen [1992] standardised likelihood ratio test rejects the null of mis-specification of the two-state regime switching model.

\subsection{Time varying information share measures}

Tables 4 and 5 present the means and standard deviations of the time varying logarithmic ratios for three information share measures in the bivariate case of one stock index and one alternative asset respectively. The results of the three sub-periods are presented separately. As can be seen in Table 4, the informational role of SSEA, with respect to the ability of adjusting to innovations in fundamental values in the long run, varies across the different stages of the COVID-19 outbreak. During P1, most of the mean log ratios are positive for the sample of SSEA and the US dollar currency index, suggesting that the SSEA index possesses higher information share, on average, compared to the US dollar currency index. Thus, the SSEA index leads the US dollar index in the long run. Oil, corn and Bitcoin have higher means of information shares relative to the SSEA index, given that most means of log ratios are negative. Hence, they play a dominant role in price discovery. During P2, all four analysed assets lead the SSEA index since most means of the log information share ratios are negative. Therefore, the SSEA index is overshadowed in this period by multiple assets. In the final stage, P3, the result is similar to that of P1, suggesting a superior role for the SSEA index relative to the US dollar index, but a subordinate role relative to oil, corn and Bitcoin. 


\section{Insert Tables 4 and 5 about here}

We calculate the changes in means of $\log$ ratios across different stages in a sequential way. From sub-period P1 to P2, means of ratios decrease for price discovery processes for the SSEA index relative to oil, US dollar index and corn, given negative changes in means. However, we identify an increase in the means of ratios for the same processes when we move from sub-periods P2 to P3. This result suggests that price discovery performance of the Chinese A-share market is adversely impacted by the domestic outbreak of the COVID-19 in China. When the pandemic is globally contagious, the price discovery role of SSEA recovers to some extent. This is the case when investigating the long-run relationships between the Chinese A-share market with the oil, corn and US dollar indices. Looking at the price discovery process of the SSEA index and Bitcoin, the means of ratios continue to fall sequentially as we move from sub-periods P1 to P3. This result suggests that when Bitcoin is considered in the pairwise price discovery process with the Chinese A-share market, the international outbreak of COVID-19 highlights the long-run informational role of the latter pair, when compared to the cases of oil, corn and US dollar index. It should be noted that all the changes in the respective means are found to be statistically significant. As can be seen from Table 5, during P1, the price discovery of the SSEB index presents similar results to those from the SSEA index during the same period. That is, on average the SSEB index plays a dominant role in the price discovery process with the US dollar index, whereas oil, corn and Bitcoin dominate the processes in relation to the SSEB index. The result suggests that the Chinese A-share and B-share markets are both led by oil, corn and the Bitcoin markets in the long run process of adjusting to innovations in the fundamental values, during a relative tranquil period ahead of the COVID-19 outbreak. This result might be attributed to the important roles for crude oil and corn in the economic growth in China such that they are deemed to be key inputs for industrial products (see for example, Luo and Ji [2018]; Li and Wei [2018]).

It was something of a surprise to find that during episodes of exceptional financial market volatility, Bitcoin was found to interact quite substantially with both the Chinese A-share and Bshare stock markets in the long run price discovery process. The result appears to be fundamentally new in the literature where prior studies conclude that few informational linkages exist between Bitcoin and major financial markets (Bouri et al. [2016]; Corbet et al. [2018]; Giudici and AbuHashish [2019]). The dominant role of Bitcoin in price discovery in the domestic Chinese stock 
markets might be due to the effects brought about via a growing interest, partly driven by the Chinese government's educational initiatives around blockchain, in the Bitcoin markets (Corbet et al. [2018]). On the other hand, the Chinese A-share and B-share stock markets both lead the US dollar index in the long run during the relative tranquil periods, suggesting the importance of China's economy, as mirrored by Chinese stock markets, to international foreign exchange markets. When focusing on sub-period P2, a similar result holds to that of P1. During the domestic contagion of COVID-19 in China, the SSEB index still plays a crucial role of price discovery in leading the US dollar index, whereas it has an inferior role in the price discovery processes in relation to oil, corn and Bitcoin. When the outbreak of the COVID-19 becomes internationally widespread, that is, during P3, we find that the SSEB index leads none of assets in the long run; instead, it is overshadowed by all four others assets.

To have a clearer view of how averaged price discovery performance of SSEB index changes throughout the COVID-19 contagion, in Table 4, we calculate changes in the means sequentially across the three sub-periods and some patterns can be identified. For samples of the SSEB index with oil, Bitcoin and corn, the means of log ratios firstly decline from sub-periods P1 to P2 and then increase for sub-periods P2 to P3. This sugests that during the domestic outbreak of COVID-19 in China (before the outbreak becomes global), the price discovery function of the SSEB index is adversely impacted. It recovers to some extent when the outbreak is acknowledged outside China. A reversed pattern is observed for the sample relating to the SSEA and US dollar index. The means of $\log$ ratios firstly increases from sub-periods P1 to P2 and then declines for sub-periods P2 to P3. It is during the global contagion of the COVID-19 that the price discovery of the SSEB index is substantially reduced relative to the US dollar index. Note that all the changes across sub-periods are statistically significant. To sum up, Tables 4 and 5 suggest the mean relative price discovery performance of SSEA and SSEB indices is indeed affected by the COVID-19 outbreak. Multiple changing patterns are found in the price discovery of stock indices with the other four assets. Those patterns also differ between SSEA and SSEB indices. Domestic contagion of the COVID-19 outbreak in China results in different effects on price discovery of the stock indices from the time of the international outbreak of the COVID-19.

\section{Insert Figure 4 about here}


Figure 4 shows how the log ratios of information share measures move across time. With respect to the movements of log ratios for the SSEA index, it can be seen that different patterns emerge across the three stages of the COVID-19 outbreak. Aligning with Table 4, the relative price discovery performance of the SSEA index to oil, US dollar index and corn moves at lower levels during P2, compared to P1. It reverts back to some extent during P3; however, for most of the time the ratios are smaller than P1. Looking at the log ratios of information share of for SSEA over Bitcoin, after November 16, 2019 the relative price discovery performance of the A-share market falls until December 30, 2019. It reverts back with some oscillations post December 30, 2019; nonetheless, for much of the time, relative performance of the SSEA index remained at lower levels than during P1. The log ratios of information share measures for SSEB exhibit different patterns across the three stages of the COVID-19 outbreak. Aligning with Table 5, the price discovery processes for SSEB with oil, Bitcoin and corn, it can be seen that the ratios remain at lower levels during P2 than P1. Although the performance of the SSEB index recovers a little during P3, it remains very low around January and February in contrast to P1. With respect to the price discovery process of the SSEB index and US dollar index, it is worth noting that the relative performance of the SSEB index falls as P3 step occurs with the performance remaining at lower levels than both sub-periods, $\mathrm{P} 1$, and P2.

\subsection{Time varying spillovers of higher moments}

Tables 6 and 7 show the means and standard deviations of the time variant net spillovers of volatility, skewness and kurtosis from the SSEA and SSEB indices to the other four assets in the short term. As can be seen from Table 6, with respect to the averaged net volatility spillovers from the SSEA index to the other four counterparts, the SSEA index is a short-run information transmitter to oil, Bitcoin and corn during all the three sub-periods. The SSEA index is found to be a short-run information receiver from the US dollar index during the same periods. Averaged net skewness spillovers show that the SSEA index is identified as a short-run information transmitter to oil and corn, but an information receiver from Bitcoin and the US dollar index during P1. Subperiods P2 and P3 suggest that the SSEA index is a short-run information transmitter to oil, corn and Bitcoin whereas the former is only an information receiver from the US dollar index. Finally, the mean net kurtosis spillovers suggest that during both sub-periods P1 and P2, the SSEA index is an information transmitter to oil and corn while it is an information receiver from Bitcoin and 
the US dollar index. During P3, the SSEA index is an information transmitter to oil, corn and Bitcoin, but an information receiver from the US dollar index. In the short-term, all the three subperiods witness a leadership of the SSEA index in transmitting volatility risk, risk of asymmetry and risk of extreme values to oil and corn markets. The three periods also agree that the US dollar index, reflecting overall performance of foreign exchange markets, plays a leading role in the short-run transmission of multiple types of risk to the SSEA index. The role of the SSEA index in transmitting information to Bitcoin varies across the three sub-periods. The result suggests that the short-run informational role of the Chinese A-share market is crucial to domestic commodity markets, but it hinges on the foreign exchange markets for the US dollar.

We are particularly interested in how information transmissions of volatility, skewness and kurtosis from the SSEA index to the other four assets change across sub-periods. In doing so we calculate the changes in means of net spillovers sequentially across sub-periods. All the changes are statistically significant. Multiple changing patterns are found and our results indicate that there are significant variations in short-run information transmissions from the SSEA index to the other four assets across different stages of the COVID-19 outbreak. Evidence indicates a significant reduction in volatility spillovers from the SSEA index to corn, oil, and the US dollar index, similar to the results found with regards to the skewness spillovers between the SSEA index and oil, the US dollar index and corn and for the kurtosis spillovers between SSEA index and bitcoin, corn and US dollar index. The impairment on transmission of volatility risk from SSEA index is more pronounced during the third stage of the COVID-19 outbreak, whereas the impairment on transmissions of asymmetry and extreme values risk from SSEA index is more pronounced during the second stage of the COVID-19 outbreak.

As can be seen from Table 7, the averaged net volatility spillovers from the SSEB index to corn is significantly positive during $\mathrm{P} 1$, suggesting the former is a short-run information transmitter to the latter. For the same period, the SSEB index is a short-run information receiver of volatility risk from the US dollar index and Bitcoin. The result changes when we move to P2 in that the SSEB index is an information transmitter of volatility risk to corn and oil, whereas the former is still an information receiver of the same risk from the US dollar index and Bitcoin. The shortrun leadership of the SSEB index in transmitting volatility risk holds during P3. With respect to the skewness spillovers, the SSEB index is a short-term information transmitter to corn, while the former is an information receiver from oil, Bitcoin and the US dollar index, during P1. These 
results remain for both sub-periods P2 and P3. The kurtosis spillovers suggest that the SSEB index plays a leading role in transmitting risk of extreme values to corn in the short run during $\mathrm{P} 1$, while at the same time the former is an information receiver from oil. As we move to P2, the SSEB index is a short-term information transmitter of kurtosis risk to oil, corn and the US dollar index, but an information receiver from oil. A similar result is found for P3. The short-run information roles of the SSEB index in transmitting risk of volatility, asymmetry and extreme values indicate the Chinese B-share market is important for explaining risk in the domestic corn market. In contrast, in the domestic oil market it is critical to explain risk about asymmetry and large price movements of the the Chinese B-share market. We also find that Bitcoin and the foreign exchange markets are able to extrapolate common volatility risk and risk of asymmetry in the Chinese B-share market.

\section{Insert Tables 6 and 7 about here}

Similar to Table 6 , we calculate changes in means of the net spillovers of volatility, skewness and kurtosis sequentially across the three sub-periods. From Table 7 all the changes are statistically significant. This means both domestic and global contagion of the COVID-19 significantly change the short-run informational roles of the SSEB index in transmitting multiple types of risk to other assets. Multiple changing patterns of averaged volatility, skewness and kurtosis spillovers from the SSEB index to other assets are evident across sub-periods. Both sub-periods P2 and P3 witness decreases in the size of mean net spillovers of volatility, skewness and kurtosis from the SSEB index to other assets. For example, when the COVID-19 is contagious in mainland China only, there are reductions in the magnitude of volatility spillovers from the SSEB index to Bitcoin and the US dollar index. During the same period, there are reductions in the size of the kurtosis spillovers from the SSEB index to oil and corn. Moreover, during the third stage of the COVID-19 outbreak, there are reductions in the short-run transmissions of volatility and skewness from the SSEB index to all the other four assets. It can also be seen that kurtosis spillovers from the SSEB index to Bitcoin and US dollar index decline during the same stage. Compared to P2, the reductions in the short-run informational roles of SSEB index are more pronounced during P3.

Figure 5 presents time varying movements of net volatility spillovers from the SSEA and SSEB indices to the other four assets across time. It can be seen that there are different patterns for net volatility spillovers from the SSEA and SSEB indices among the four assets. Focusing on large 
variations in net spillovers around two critical dates, November 16, 2019 and December 30, 2019 and the net volatility spillovers from the SSEA and SSEB indices to oil, it can be seen there is an obvious reverse U-shaped movement with a sharp increase, followed by a sudden and large fall around November 16, 2019. For the spillover between the SSEA index and oil, similar patterns can be seen around November 16, 2019 and December 30. Moreover, the net volatility spillovers from the SSEA and SSEB indices to the Bitcoin market show a similar reverse U-shaped movement around both November 16, 2019 and December 30, 2019. Apart from these reverse U-shaped movements, net volatility spillovers are close to zero, most of the time. The moving patterns of net volatility spillovers to Bitcoin strongly suggests that the COVID-19 outbreak affected the short-run information roles of the Chinese A- and B-share stock markets in transmitting risk. The effect is more pronounced after COVID-19 is officially announced by the WHO and becomes globally contagious. It is worth noting that a U-shaped movement appears just after December 30, 2019, with respect to the net volatility spillover from the SSEB index to US dollar index. Concentrating on the movements of net volatility spillovers from the SSEB index to corn, reverse U-shaped, and U-shaped movements appear around November 16, 2019 and December 30, 2019, respectively, with a sudden large drop in net volatility spillovers from the SSEA index to corn after December 30, 2019. Such evidence of substantial variations of net volatility spillovers around these critical dates of the COVID-19 outbreak show the impact of the COVID-19 outbreak on the transmission of volatility risk in the Chinese stock markets.

\section{Insert Figure 5 and both Tables 8 and 9 about here}

In addition, Tables 8 and 9 summarise some news and events reported by the Financial Times that occurred during the whole sample period. In these tables, we trace the news with some large variations of net volatility spillovers in Figure 5 as well as those around November 16, 2019 and December 30, 2019. In doing so we are able to highlight some specific and large variations observed within each period illustrating what takes place to underlie the variations. It is noteworthy that we can see some large changes in net spillovers are associated with corresponding news Take for example, the movements of net volatility spillovers from the SSEA and SSEB indices and their

effects on the oil market. In Table 8 a reverse U-shaped movement of net volatility spillovers from the SSEA index to oil can be seen from late July to August in 2019. Such a change corresponds 
with the decision made by the European Union to rewrite budget rules, as can be seen from Table 8. Also, a large increase in net volatility spillovers from the SSEA index to oil starts in mid-October 2019 as shown in Table 8. Also from Table 8, the effect might relate to an adverse response inside the UK with respect to Brexit conducted by the UK government on October 18, 2019. In Table 9, we can see that on December 31, 2019 investors' optimistic views led to some changes in the bond market in China. This event coincides with a large decline inf net volatility spillover from the SSEB index to oil following the official announcement by WHO about the COVID-19 outbreak. Table 9 also refers to the September 17, 2019 oil price shocks following the Saudi supply disruption. This news might explain some of the small movements in net volatility spillovers from the SSEB index to oil in September 2019. Similar explanations using information from Tables 8 and 9 could also apply to the specific movements of net volatility spillovers from the SSEA and SSEB indices to the other three assets.

\section{Insert Figure 6 about here}

The movements in the net skewness spillovers from the SSEA and SSEB indices to the other four assets are shown in Figure 6. Dramatic movements are observed around critical points relating to the COVID-19 outbreak. In terms of net spillovers from the SSEB index to oil, a sharp increase is observed after November 16, 2019, with a reverse U-shape movement occuring around December 30, 2019 with a large drop after that date. Turning to the net skewness spillovers from the SSEA and SSEB indices to Bitcoin, a small increase is observed after November 16, 2019 for the spillovers from the SSEA index to Bitcoin. Two U-shaped movements of net spillovers from the SSEB to Bitcoin occur after November 16, 2019 and after December 30, 2019, respectively. Similarly, the net skewness spillover from the SSEA index to the US dollar index leads to two U-shaped movements after November 16, 2019 and after December 30, 2019, respectively. A small sudden drop of net spillovers from the SSEA index to the US dollar can be seen after November 16, 2019. Finally, dramatic decreases in net skewness spillovers from the SSEA and SSEB indices to corn following these two dates can be seen from the figure. From these observations, we have a clear view of the

impacts of the COVID-19 outbreak on the transmissions of risk of asymmetry in the Chinese stock markets.

In Tables 10 and 11, we present a range of news and events that possibly relate to some large 
and specific movements in the net skewness spillovers in Figure 6. By using information from the two tables, we can explain some large and specific variations other than those occurring around November 16, 2019 and December 30, 2019 in Figure 6. Considering the movements of net skewness spillovers from the SSEA and SSEB indices to corn for example, in Figure 6, we can see that there are a few reverse U-shaped movements of net skewness spillovers from the SSEA and SSEB indices to corn in February and March, 2020. Tables 10 shows that there were several events taking place in February 2020 that might relate to the oscillations of net skewness spillovers from the SSEA index to corn for example, on February 5, 2020, an executive in the top US Softbank Vision Fund suggested he would leave his position, which unleashed some concerns about bad debts at the fund. On February 13, 2020, some new patents reviewed by the Financial Times suggested that China was pushing to digitise the Renminbi. On February 24, 2020, COVID-19 led to 10 towns being locked down in Italy. These events, particularly the last two, might have had some significant effects on the interdependence of asymmetry between the SSEA index and the corn market as they may have triggered abnormal behaviour from domestic investors in China.

\section{Insert Table 10 and 11 about here}

Table 11 shows that there is one further event that occurs on February 21, 2020, that is, Morgan Stanley secured a $\$ 13$ billion deal for E-trade which is an online brokerage and digital bank. Such digital technology is expected to help Morgan Stanley reach everyday investors more profitably and achieve a better view of overall household finances. Together with events on February 13 and 24, 2020, this event might be able to contribute to two adjacent reverse U-shaped variations of net skewness spillovers from the SSEB index to corn in February and March, 2020, since they might influence the trading behaviour of foreign investors response to the interdependence of asymmetry between the SSEB index and corn. Similar explanations may be relevant for other specific oscillations of the net skewness spillovers shown in Figure 6 by using information provided in Tables 10 and 11.

\section{Insert Figure 7 and both Tables 12 and 13 about here}

Figure 7 shows the movements of net kurtosis spillovers from the SSEA and SSEB indices to the other four assets over time. Similar to Figures 5 and 6 , it can be seen that there are large variations 
of net kurtosis spillovers around November 162019 and December 20 2020. For example, there is a large reverse U-shaped movement around November 162020 and a large U-shaped movement immediately after December 302020 for the net kurtosis spillover from the SSEA index to oil. There is also a gradual increase after December 302020 for the net kurtosis spillover from the SSEB index to oil. Furthermore, there is a U-shaped movement after November 162019 for the net kurtosis spillover from the SSEA index to Bitcoin. Two important U-shaped movements are also discernable after November 162019 and after December 302020 for the net kurtosis spillover from SSEB index in relation to Bitcoin. A small increase is also detected after November 162019 for the net kurtosis spillover from the SSEA index to the US dollar index while there is also a small decrease after December 302020 for the net kurtosis spillover from the SSEB index to US dollar index. Finally, two sudden drops occur after November 162019 for both the net kurtosis spillovers from the SSEA and SSEB indices to corn. There are also two sharp increases around December 30, 2020 for both the net kurtosis spillovers from the SSEA and SSEB indices to corn, followed by gradual declines afterwards. These observations suggest that both domestic and international contagions of the COVID-19 impact the transmission of risk of extreme values from the Chinese stock markets, in addition to the effects on transmissions of volatility and skewness.

Similarly, we also detect some specific and large variations at other times than November 16 2020 and December 302020 in Figure 7. Tables 12 and 13 provide detailed information on new and events reported by the Financial Times that take occur which correspond with those variations. We use Tables 12 and 13 to explain some variations of the net kurtosis spillovers from the SSEA and SSEB indices to oil, which is an important explanation of variations of the net kurtosis spillovers from the SSEA and SSEB indices to the other assets. In Figure 6, there is a signifiicant reverse U-shaped movement in July and August 2019 in relation to the net kurtosis spillover from the SSEA index to oil. Table 13 suggests that such movements may be related to the news on July 29 2019 that automobile producers in China experienced reduced sales in vehicles. Figure 6 shows that there are two U-shaped movements of the net kurtosis spillovers from the SSEA and SSEB indices to oil in December 2019. As can be seen from Table 12, on December 17 2019, positive responses in the UK stock market were reported as positive responses to the Brexit plan. One might expect that this news changed the information content of the crude oil prices and may relate to the specific movements of net kurtosis spillovers from the Chinese stock markets to oil in December 2020. Finally, Figure 6 shows that there are a few dramatic oscillations from late January 2020 to the end 
point of the full sample period, for the net kurtosis spillovers from the SSEA index to oil. Some early movements might be related to the lock-down of Wuhan City and Hubei Province in late January 2020. Some oscillations in February may be related to the fact that China's government decided to deploy emergency funds to shield markets from the virus fallout, which was reported on February 32020.

\section{Insert Figure 8 about here}

Figure 8 presents the differences in net volatility spillovers between the SSEA and SSEB indices. We subtract net spillovers in the SSEB index from the SSEA index. The subtraction produces a net gap between SSEA and SSEB in respect to the transmission of volatility risk. The figure shows that the net gap exhibits different patterns for the different periods of the COVID-19 outbreak, compared to a relatively tranquil period before the outbreak occurs. In terms of the volatility spillovers from the SSEA and SSEB indices to oil, the SSEA index dominates the SSEB index in the transmission for most of the time. The dominance gradually increases across the three stages of the COVID-19 outbreak. When looking at the volatility spillovers from the SSEA and SSEB indices to the the US dollar index, the SSEB index dominates the SSEA index in terms of the transmissions during the two stages of the COVID-19 outbreak. The dominant effect is enhanced during the two stages of the COVID-19 outbreak. This becomes more intensive during the global contagion of the COVID-19. It is also interesting to see the net gap with respect to the volatility spillovers to corn. The SSEA index dominates the SSEB index prior to the COVID-19 outbreak. However, this dominance is significantly affected by the domestic outbreak of COVID-19. It recovers to higher levels post February 2020.

\section{Insert Figure 9 about here}

Like Figure 8, Figure 9 shows moving patterns of the net gap between SSEA and SSEB indices with respect to their strength in transmitting risk of asymmetry. SSEA index has a higher power than SSEB index in the transmissions to oil. The dominance is squeezed during the domestic cognation of the COVID-19 but it reinstates during the stage of global contagion. The dominance of SSEA over SSEB is also observed in the transmission to bitcoin. The dominating effect increases 
across time and it achieves at highest level at the final stage. We find SSEB index dominates SSEA index in transmitting risk of asymmetry to US dollar index. The effect is impaired by domestic outbreak of the COVID-19 but it gets even higher during the global contagion of the virus. Such effect is reversed after February 2020. It is also found that SSEB index dominates SSEA index in the spillover process to corn, specifically during the two stages of the COVID-19 outbreak. The dominating effect is more intensive during the final stage.

\section{Insert Figure 10 about here}

Figure 10 suggests a similar result as shown in Figure 8. The SSEA index dominates the SSEB index in transmitting risk of extreme values to oil. Such an effect increases over time achievings the largest effect in the third stage of the COVID-19 outbreak. The SSEB index dominates the SSEA index in terms of the transmissions of risk of extreme values to the US dollar index. The effect is somewhat reduced during the domestic contagion of the COVID-19, whereas it increases as the global contagion progresses. Overall, the results in Figures 8, 9 and 10 suggest that the Chinese A-share market has an more important informational role forcrude oil prices in China in the short run, whereas the Chinese B-share market has a more important short-run informational role effect in terms of the foreign exchange market. These results appear to be more important when COVID-19 becomes more globally intensive.

\subsection{Robustness check and further discussions}

In this section, we consider to elements of robustness checks. Firstly, we estimate static results of information share measures and net spillovers of higher moments. We then compare the static results with dynamic effects. Secondly, we estimate the results of the information share measures and net spillovers of higher moments using 5 -minute data. We examine whether the results for 5-minute data support our main results on the effects of the COVID-19 outbreak based 30-minute data.

Static logarithmic ratios of information share measures for the SSEA and SSEB indices are presented in Tables 14 and 15. In terms of the the long-run price discovery performance of both indices throughout the three sub-periods, time varying results in Tables 4 and 5 are consistent across sub-periods. Dynamic results are clearer in terms of understanding results than those constrained 
to be static, since the former allows more information from the time variations in the data to be modelled. In this paper we are more interested in changes in the static log ratios across sub-periods. Tables 14 and 15 show that there are reductions in the ratios of SSEA over oil and corn from subperiods P1 to P2 and increases in the same ratios from sub-periods P2 to P3. There are increases in the ratios of SSEA over Bitcoin and the US dollar index from sub-periods P1 to P2 and decreases in the same ratios from sub-periods P2 to P3. There are also decreases in the ratios of SSEB in terms of the US dollar index, over Bitcoin and corn from sub-periods P1 to P2 and increases in the same ratios from sub-periods $\mathrm{P} 2$ to P3. There is an increase in the ratio of the SSEB over oil from sub-periods P1 to P2 and a decrease in the same ratio from sub-periods P2 to P3. Compared to Tables 4 and 5 , the results in terms of changes in static price discovery performance of the SSEA and SSEB indices are qualitative similar to the dynamic results. Both static and dynamics results point to the impacts of the COVID-19 outbreak on the long-run price discovery processes of the Chinese stock markets in terms of other assets.

\section{Insert Tables 14 through 17 about here}

Tables 16 and 17 show static net spillovers of volatility, skewness and kurtosis from the SSEA and SSEB indices to the four other assets. Likewise, dynamic results of the short-run informational roles of the two indices in Tables 6 and 7 suggest additional information compared to those in Tables 16 and 17. The dynamic results are more consistent across sub-periods and also somewhat clearer to understand than the static results. Focusing on the between-P changes in static net spillovers, multiple patterns of changes are found across sub-periods in the spillovers of volatility, skewness and kurtosis. For example, the net volatility spillover from SSEA to oil decreases from sub-periods P1 to P2 and decreases further from sub-periods P2 to P3. The net skewness spillover from the SSEA index to oil decreases only from sub-periods P2 to P3. The net kurtosis spillover from SSEA to oil initially increases from sub-periods P1 to P2 and then decreases from sub-periods P2 to P3. Meanwhile, the net volatility spillover from the SSEB index to US dollar index decreases from sub-periods P1 to P2 and decreases further from sub-periods P2 to P3. The net skewness spillover from SSEB to the US dollar index decreases for sub-periods P2 to P3. However, the net kurtosis spillover from SSEB to US dollar index decreases only for sub-periods P2 to P3. Overall, changes in the static net spillovers of higher moments from the SSEA and SSEB indices to other assets 
are qualitatively similar to the changes in those derived for the dynamic alternatives. Both static and dynamics results identify the impacts of the COVID-19 outbreak on the short-run information transmissions from the Chinese stock markets to other assets.

The estimation results from 5-minute data are shown in the Appendix. Specifically, the results of the static and time varying information share measures are shown in Tables A4 through A7. The between-P changes are all statistically significant. Similarly, the changing patterns in the short-run information transmissions of the SSEA and SSEB indices across sub-periods from the 5-minute data are qualitatively similar as those from the 30-minute data. The changes across sub-periods are all statistically significant. Overall, the results from the 5-minute data support the main results from 30-minute data.

\section{Concluding Comments}

There is no doubt that the COVID-19 outbreak and consequential pandemic are the most influential events of early 2020, which have deeply effected economic, political and social normality at a global level. One significant question surrounds as to whether the behaviour of the pricing dynamics of financial markets and subsequent contagion relating to the COVID-19 outbreak in China differed during the period when the outbreak was first identified in China. Evidence to date sheds light on an the on-going debate as to how information about COVID-19 disseminated among investors in mainland China since the first case was confirmed in November 2020. Subsequent accusations of information shrouding have since emerged. However, there is evidence to suggest that before the official WHO announcements, there existed both media and social media coverage of a 'mystery pneumonia' or 'mystery flu' in China.

This study attempts to quantify the long-run price discovery and short-run informational spillovers that stock markets in China exert towards other financial markets during this time period. Such research would subsequently present evidence that suggests that although the information was local in nature, it was available to Chinese citizens and the global market alike, but was simply not recognised internationally in terms of the weight that it should have been attributed, with hindsight.

Based upon a robust methodological framework, we use prices at 30-minute intervals, and three information share measures to examine the long-run price discovery from the SSEA and SSEB indices, in terms of the Chinese crude oil futures, Chinese corn futures, Bitcoin and the US the US dollar currency index. A two-state regime switching model is used to calculate the conditional series 
of higher moments of bivariate return distributions including variance, skewness and kurtosis. Based upon the higher moments' series, the short-run net informational spillovers of higher moments from the SSEA or SSEB indices to alternative assets are estimated. We present results for both static and the time varying results for information share and informational spillovers, with a specific focus of the latter.

Our results suggest a number of key points that are relevant to both investors and regulators under conditions created by the pandemic. With respect to the time-varying net spillovers of higher moments from the SSEA and SSEB indices to other assets, the SSEA index is an information transmitter to domestic crude oil and corn markets in the short run, whereas it receives information shocks from the US dollar index. The evidence also applies to the transmissions of volatility risk, risk of asymmetry and risk of extreme values. Both the volatility and skewness spillovers are found to be an information transmitter from the SSEA to the Bitcoin market, while kurtosis spillovers identify a net transmission in the opposite direction. However, the informational role of Bitcoin is substantively weakened as the COVID-19 outbreak becomes more severe. However the SSEB index is a short-run information transmitter to the domestic corn market, which is the case for all types of risk transmissions. Both volatility and skewness spillovers from the SSEB is found to act as a short-run information receiver from both the US dollar index and Bitcoin markets, while the SSEB is shown to be as a short-run information transmitter to both oil and corn markets in terms of the kurtosis spillovers.

Domestic crude oil market play a leading role in both the skewness and kurtosis spillovers to the SSEB index, whereas the former is led by the latter in terms of the volatility spillover. More importantly, we find the short-run informational spillovers significantly change across stages of the domestic and global contagion of the COVID-19. Furthermore, we detect substantively large variations in movements of the information share and higher moments' spillovers around two important dates after where the domestic and global COVID-19 outbreaks are identified. These results reflect the responses of investors to the progression of COVID-19.

Such evidence relating of the significant variations of information content sourced from Chinese stock markets across the various stages of the COVID-19 outbreak, suggest that investors who trade in the Chinese stock markets, including both domestic and foreign investigators, were aware of COVID-19 at early stages of the outbreak in November and December 2019. This is in line with similar identified dates of information released through Chinese media sources. Furthermore, 
we identify large variations in the movements of information share and higher moments' spillovers around two critical dates after which domestic and global COVID-19 outbreaks respectively are identified. In particular, the Chinese A-share market has an important informational role of the crude oil price. The Chinese B-share market has a short-run informational influence on the foreign exchange market. These roles are intensified as the COVID-19 is globally contagious and severe. Further, the majority Chinese-traded financial markets in the form of the SSEA present evidence of elevated information and response across a number of moments at much earlier stages when compared to the more internationally-traded SSEB. It suggests that financial markets in China recognised the dangers associated with COVID-19 in advance of the rest of the world, a result that does not suggest government collusion such as that identified by other international governments, but rather that local news in China did not filter throughout international broadcasters and that international investors did not identify COVID-19 in its infancy.

Finally, while evidence of the safe-haven and flight-to-safety behaviour is evident across traditional energy and precious metal market, such as that of Chinese oil and gold markets, our results suggest that cryptocurrencies, such as Bitcoin offered another platform through which wealth was stored during periods of pandemic-related volatility. Cryptocurrencies as a hedging mechanism during periods of financial market chaos, while further validating the product's place as a credible financial market asset, would cause particular concern for regulators and policy-makers due to the wide-ranging issues present with regards to illicit usage, manipulation and broad instability.

\section{References}

Ahuja, R., S. Barrett, S. Corbet, and C. Larkin (2019). A way forward: The future of irish and european union financial regulation. Economic Analysis and Policy 64, 346-360.

Aktas, N., E. De Bodt, and H. Van Oppens (2008). Legal insider trading and market efficiency. Journal of Banking \& Finance 32(7), 1379-1392.

Akyildirim, E., S. Corbet, P. Katsiampa, N. Kellard, and A. Sensoy (2019). The development of bitcoin futures: Exploring the interactions between cryptocurrency derivatives. Finance Research Letters.

Allen, F. and E. Carletti (2013). What is systemic risk? Journal of Money, Credit and Banking 45(SUPPL 1), $121-127$.

Allen, F. and D. Gale (1998). Optimal financial crises. Journal of Finance 53(4), 1245-1284.

Alvarez, F. E., D. Argente, and F. Lippi (2020). A simple planning problem for covid-19 lockdown. Technical report, National Bureau of Economic Research.

Anand, A., V. Gatchev, L. Madureira, C. Pirinsky, and S. Underwood (2011). Geographic proximity and price discovery: Evidence from nasdaq. Journal of Financial Markets 14(2), 193-226. 
Bailey, W. (1994). Risk and return on china's new stock markets: Some preliminary evidence. Pacific-Basin Finance Journal 2(2-3), 243-260.

Baillie, R. T., G. G. Booth, Y. Tse, and T. Zabotina (2002). Price discovery and common factor models. Journal of financial markets 5(3), 309-321.

Barrett, S., S. Corbet, and C. Larkin (2019). Sustainability, accountability and democracy: Ireland's troika experience. Finance Research Letters 28, 53-60.

Barrett, S., S. Corbet, and C. Larkin (2020). Public accountability and parliamentary scrutiny in finance. European Journal of Risk Regulation 11(1), 94-108.

Booth, G. G., J.-C. Lin, T. Martikainen, and Y. Tse (2002). Trading and pricing in upstairs and downstairs stock markets. The Review of Financial Studies 15(4), 1111-1135.

Booth, G. G., R. W. So, and Y. Tse (1999). Price discovery in the german equity index derivatives markets. Journal of Futures Markets: Futures, Options, and Other Derivative Products 19(6), 619-643.

Bouri, E., G. Azzi, and A. H. Dyhrberg (2016). On the return-volatility relationship in the bitcoin market around the price crash of 2013. Available at SSRN 2869855.

Brandvold, M., P. Molnár, K. Vagstad, and O. Andreas Valstad (2015). Price discovery on bitcoin exchanges. Journal of International Financial Markets, Institutions and Money 36, 18-35.

Cai, C., P. McGuinness, and Q. Zhang (2011). The pricing dynamics of cross-listed securities: The case of chinese a- and h-shares. Journal of Banking and Finance 35(8), 2123-2136.

Cavallo, E. and P. Valenzuela (2010). The determinants of corporate risk in emerging markets: An option-adjusted spread analysis. International Journal of Finance and Economics 15(1), 59-74.

Chakravarty, S. and J. J. McConnell (1999). Does insider trading really move stock prices? Journal of Financial and Quantitative Analysis 34(2), 191-209.

Chakravarty, S., A. Sarkar, and L. Wu (1998). Information asymmetry, market segmentation and the pricing of cross-listed shares: Theory and evidence from chinese a and b shares. Journal of International Financial Markets, Institutions and Money 8(3-4), 325-356.

Chan, K. and N.-F. Chen (1991). Structural and return characteristics of small and large firms. The Journal of Finance 46(4), 1467-1484.

Chan, K., A. Menkveld, and Z. Yang (2007). The informativeness of domestic and foreign investors' stock trades: Evidence from the perfectly segmented chinese market. Journal of Financial Markets 10(4), 391-415.

Chan, K., J. Yang, and Y. Zhou (2018). Conditional co-skewness and safe-haven currencies: A regime switching approach. Journal of Empirical Finance 48, 58-80.

Chan, L., D. Lien, and W. Weng (2008). Financial interdependence between hong kong and the us: A band spectrum approach. International Review of Economics and Finance 17(4), 507-516.

Chang, G.-D. and C.-S. Chen (2014). Evidence of contagion in global reits investment. International Review of Economics and Finance 31, 148-158.

Chang, R. and A. Velasco (2001). A model of financial crises in emerging markets. Quarterly Journal of Economics $116(2), 489-517$. 
Chen, G., B.-S. Lee, and O. Rui (2001). Foreign ownership restrictions and market segmentation in china's stock markets. Journal of Financial Research 24(1), 133-155.

Chen, H. and P. Choi (2012). Does information vault niagara falls? cross-listed trading in new york and toronto. Journal of Empirical Finance 19(2), 175-199.

Chen, H., P. De, Y. J. Hu, and B.-H. Hwang (2014). Wisdom of crowds: The value of stock opinions transmitted through social media. The Review of Financial Studies 27(5), 1367-1403.

Chen, Y.-L. and Y.-F. Gau (2010a). News announcements and price discovery in foreign exchange spot and futures markets. Journal of Banking and Finance 34(7), 1628-1636.

Chen, Y.-L. and Y.-F. Gau (2010b). News announcements and price discovery in foreign exchange spot and futures markets. Journal of Banking \& Finance 34(7), 1628-1636.

Chen, Y.-L. and W.-C. Tsai (2017). Determinants of price discovery in the vix futures market. Journal of Empirical Finance 43, 59-73.

Choy, S.-K. and H. Zhang (2010). Trading costs and price discovery. Review of Quantitative Finance and Accounting $34(1), 37-57$.

Chui, A. and C. Kwok (1998). Cross-autocorrelation between a shares and b shares in the chinese stock market. Journal of Financial Research 21(3), 333-353.

Conlon, T., S. Corbet, and R. McGhee (2020). Are Cryptocurrencies a Safe Haven for Equity Markets? An International Perspective from the COVID-19 Pandemic. Research in International Business and Finance (forthcoming) 101248.

Corbet, S. (2016). Turning Tigers into PIIGS: The Role of Leverage in the Irish Economic Collapse. Advances in Sustainability and Environmental Justice 18, 21-55.

Corbet, S. and D. J. Cumming (2020). The Wild West of ICOs. Available at SSRN 3550850.

Corbet, S., G. Hou, Y. Hu, B. M. Lucey, and L. Oxley (2020). Aye Corona! The Contagion Effects of Being Named Corona during the COVID-19 Pandemic. Finance Research Letters 101591.

Corbet, S., Y. Hu, Y. G. Hou, C. Larkin, and L. Oxley (2020). Any port in a storm: Cryptocurrency safe-havens during the covid-19 pandemic. Available at SSRN.

Corbet, S., Y. Hu, Y. G. Hou, and L. Oxley (2020). Pandemic-related financial market volatility spillovers: Evidence from the Chinese COVID-19 epicentre. International Review of Economics \& Finance (forthcoming).

Corbet, S. and C. Larkin (2017). Has the uniformity of banking regulation within the european union restricted rather than encouraged sectoral development? International Review of Financial Analysis 53, 48-65.

Corbet, S., C. Larkin, B. Lucey, and L. Yarovaya (2020). Kodakcoin: a blockchain revolution or exploiting a potential cryptocurrency bubble? Applied Economics Letters 27(7), 518-524.

Corbet, S., C. J. Larkin, and B. M. Lucey (2020). The Contagion Effects of the COVID-19 Pandemic: Evidence from Gold and Cryptocurrencies. Finance Research Letters, Forthcoming, Available at: http://dx.doi.org/10.2139/ssrn.3564443.

Corbet, S., C. J. Larkin, B. M. Lucey, A. Meegan, and L. Yarovaya (2018). The volatility generating effects of macroeconomic news on cryptocurrency returns. Available at SSRN 3141986. 
Corbet, S., B. Lucey, M. Peat, and S. Vigne (2018). Bitcoin futures-what use are they? Economics Letters 172, $23-27$.

Corbet, S., A. Meegan, C. Larkin, B. Lucey, and L. Yarovaya (2018). Exploring the dynamic relationships between cryptocurrencies and other financial assets. Economics Letters 165, 28-34.

Covitz, D., N. Liang, and G. Suarez (2013). The evolution of a financial crisis: Collapse of the asset-backed commercial paper market. Journal of Finance 68(3), 815-848.

De Jong, F. (2002). Measures of contributions to price discovery: A comparison. Journal of Financial Markets 5(3), $323-327$.

Del Brio, E. B., A. Mora-Valencia, and J. Perote (2017). The kidnapping of europe: High-order moments' transmission between developed and emerging markets. Emerging Markets Review 31, 96-115.

Donaldson, R. (1992). Sources of panics. evidence from the weekly data. Journal of Monetary Economics 30(2), $277-305$

Engle, R. F. and C. W. Granger (1987). Co-integration and error correction: representation, estimation, and testing. Econometrica: journal of the Econometric Society, 251-276.

Eun, C. and W. Huang (2007). Asset pricing in china's domestic stock markets: Is there a logic? Pacific Basin Finance Journal 15(5), 452-480.

Fricke, C. and L. Menkhoff (2011). Does the " bund" dominate price discovery in euro bond futures? examining information shares. Journal of Banking and Finance 35(5), 1057-1072.

Frijns, B., A. Gilbert, and A. Tourani-Rad (2010). The dynamics of price discovery for cross-listed shares: Evidence from australia and new zealand. Journal of Banking and Finance 34(3), 498-508.

Frijns, B., A. Gilbert, and A. Tourani-Rad (2015). The determinants of price discovery: Evidence from us-canadian cross-listed shares. Journal of Banking and Finance 59, 457-468.

Fung, H.-G., W. Lee, and W. Leung (2000). Segmentation of the a- and b-share chinese equity markets. Journal of Financial Research 23(2), 179-195.

Gandal, N., J. Hamrick, T. Moore, and T. Oberman (2018). Price manipulation in the bitcoin ecosystem. Journal of Monetary Economics 95, 86-96.

Giudici, P. and I. Abu-Hashish (2019). What determines bitcoin exchange prices? a network var approach. Finance Research Letters 28, 309-318.

Gonzalo, J. and C. Granger (1995). Estimation of common long-memory components in cointegrated systems. Journal of Business \& Economic Statistics 13(1), 27-35.

Gorton, G. and A. Metrick (2012). Securitized banking and the run on repo. Journal of Financial Economics 104(3), 425-451.

Grammig, J., M. Melvin, and C. Schlag (2005). Internationally cross-listed stock prices during overlapping trading hours: Price discovery and exchange rate effects. Journal of Empirical Finance 12(1), 139-164.

Gray, S. F. (1996). Modeling the conditional distribution of interest rates as a regime-switching process. Journal of Financial Economics 42(1), 27-62.

Griffin, J. M. and A. Shams (2018). Is bitcoin really un-tethered? Available at SSRN 3195066. 
Hansen, B. E. (1992). The likelihood ratio test under nonstandard conditions: testing the markov switching model of gnp. Journal of applied Econometrics 7(S1), S61-S82.

Harris, F., T. McInish, and R. Wood (2002a). Security price adjustment across exchanges: An investigation of common factor components for dow stocks. Journal of Financial Markets 5(3), 277-308.

Harris, F. H. d., T. H. McInish, and R. A. Wood (2002b). Security price adjustment across exchanges: an investigation of common factor components for dow stocks. Journal of financial markets 5(3), 277-308.

Hasbrouck, J. (1995). One security, many markets: Determining the contributions to price discovery. The journal of Finance 50(4), 1175-1199.

Hasbrouck, J. (2002). Stalking the "efficient price" in market microstructure specifications: An overview. Journal of Financial Markets 5(3), 329-339.

He, Q. and C. Fang (2019). Regulatory sanctions and stock pricing efficiency: Evidence from the chinese stock market. Pacific Basin Finance Journal 58.

Huddart, S., J. S. Hughes, and C. B. Levine (2001). Public disclosure and dissimulation of insider trades. Econometrica $69(3), 665-681$.

Iihara, Y., K. Kato, and T. Tokunaga (1996). Intraday return dynamics between the cash and the futures markets in japan. The Journal of Futures Markets (1986-1998) 16(2), 147.

Kamradt-Scott, A. (2013). The politics of medicine and the global governance of pandemic influenza. International Journal of Health Services 43(1), 105-121.

Kamradt-Scott, A. (2015). Managing global health security: The world health organization and disease outbreak control.

Katsiampa, P., S. Corbet, and B. Lucey (2019a). High frequency volatility co-movements in cryptocurrency markets. Journal of International Financial Markets, Institutions and Money 62, 35-52.

Katsiampa, P., S. Corbet, and B. Lucey (2019b). Volatility spillover effects in leading cryptocurrencies: A BEKKMGARCH analysis. Finance Research Letters 29, 68-74.

Kroszner, R. (1999). Can the financial markets privately regulate risk? the development of derivatives clearinghouses and recent over-the-counter innovations. Journal of Money, Credit and Banking 31(3), 590-618.

Lan, Y., Y. Huang, and C. Yan (2020). Investor sentiment and stock price: Empirical evidence from chinese seos. Economic Modelling.

Li, X. and Y. Wei (2018). The dependence and risk spillover between crude oil market and china stock market: New evidence from a variational mode decomposition-based copula method. Energy Economics 74, 565-581.

Lien, D. and K. Shrestha (2014). Price discovery in interrelated markets. Journal of Futures Markets 34(3), 203-219.

Lin, C.-B., R. Chou, and G. Wang (2018). Investor sentiment and price discovery: Evidence from the pricing dynamics between the futures and spot markets. Journal of Banking and Finance 90, 17-31.

Lin, W.-Y. and I.-C. Tsai (2019). Trader differences in shanghai's a-share and b-share markets: Effects on interaction with the shanghai housing market. Journal of Asian Economics 64.

Los, C. and B. Yu (2008). Persistence characteristics of the chinese stock markets. International Review of Financial Analysis 17(1), 64-82. 
Luo, J. and Q. Ji (2018). High-frequency volatility connectedness between the us crude oil market and china's agricultural commodity markets. Energy Economics 76, 424-438.

Luo, X., J. Zhang, and W. Duan (2013). Social media and firm equity value. Information Systems Research 24(1), $146-163$.

Meegan, A., S. Corbet, and C. Larkin (2018). Financial market spillovers during the quantitative easing programmes of the global financial crisis (2007-2009) and the european debt crisis. Journal of International Financial Markets, Institutions and Money 56, 128-148.

Mei, J., J. Scheinkman, and W. Xiong (2009). Speculative trading and stock prices: Evidence from chinese a-b share premia. Annals of Economics and Finance 10(2), 225-255.

Meng, Q., X. Li, K. Chan, and S. Gao (2020). Does short selling affect a firm's financial constraints? Journal of Corporate Finance 60.

Muravyev, D., N. Pearson, and J. Paul Broussard (2013). Is there price discovery in equity options? Journal of Financial Economics 107(2), 259-283.

Nimalendran, M. and S. Ray (2014). Informational linkages between dark and lit trading venues. Journal of Financial Markets 17(1), 230-261.

Page, S., H. Song, and D. Wu (2012). Assessing the impacts of the global economic crisis and swine flu on inbound tourism demand in the united kingdom. Journal of Travel Research 51(2), 142-153.

Pascual, R., B. Pascual-Fuster, and F. Climent (2006). Cross-listing, price discovery and the informativeness of the trading process. Journal of Financial Markets 9(2), 144-161.

Peckham, R. (2013). Economies of contagion: Financial crisis and pandemic. Economy and Society 42(2), 226-248.

Putniňš, T. J. (2013). What do price discovery metrics really measure? Journal of Empirical Finance 23, 68-83.

Qi, D., W. Wu, and H. Zhang (2000). Shareholding structure and corporate performance of partially privatized firms: Evidence from listed chinese companies. Pacific Basin Finance Journal 8(5), 587-610.

Qiao, K. and L. Dam (2020). The overnight return puzzle and the " $\mathrm{t}+1$ " trading rule in chinese stock markets. Journal of Financial Markets.

Sadique, M., W. Edmunds, R. Smith, W. Meerding, O. De Zwart, J. Brug, and P. Beutels (2007). Precautionary behavior in response to perceived threat of pandemic influenza. Emerging Infectious Diseases 13(9), 1307-1313.

Schuppli, M. and M. Bohl (2010). Do foreign institutional investors destabilize china's a-share markets? Journal of International Financial Markets, Institutions and Money 20(1), 36-50.

$\mathrm{Su}$, Q. and T.-L. Chong (2007). Determining the contributions to price discovery for chinese cross-listed stocks. Pacific Basin Finance Journal 15(2), 140-153.

Tan, L., T. Chiang, J. Mason, and E. Nelling (2008). Herding behavior in chinese stock markets: An examination of a and b shares. Pacific Basin Finance Journal 16(1-2), 61-77.

Theissen, E. (2012). Price discovery in spot and futures markets: A reconsideration. European Journal of Finance 18(10), 969-987.

Tse, Y. (1999). Price discovery and volatility spillovers in the djia index and futures markets. Journal of Futures markets 19(8), 911-930. 
Wang, J. and M. Yang (2011). Housewives of tokyo versus the gnomes of zurich: Measuring price discovery in sequential markets. Journal of Financial Markets 14(1), 82-108.

Wang, S. and L. Jiang (2004). Location of trade, ownership restrictions, and market illiquidity: Examining chinese a- and h-shares. Journal of Banking and Finance 28(6), 1273-1297.

Wang, Y. and A. Iorio (2007). Are the china-related stock markets segmented with both world and regional stock markets? Journal of International Financial Markets, Institutions and Money 17(3), 277-290.

Wang, Y., Y. Wei, and C. Wu (2010). Cross-correlations between chinese a-share and b-share markets. Physica A: Statistical Mechanics and its Applications 389(23), 5468-5478.

Weiss, N. (2012). Banking and financial infrastructure continuity: Pandemic flu, terrorism, and other challenges.

Xianghai, M. (1996). Capital controls, market segmentation and stock prices: Evidence from the chinese stock market. Pacific Basin Finance Journal 4(2-3), 219-239.

Yan, B. and E. Zivot (2010a). A structural analysis of price discovery measures. Journal of Financial Markets 13(1), $1-19$.

Yan, B. and E. Zivot (2010b). A structural analysis of price discovery measures. Journal of Financial Markets 13(1), $1-19$.

Yao, J., C. Ma, and W. He (2014). Investor herding behaviour of chinese stock market. International Review of Economics and Finance 29, 12-29.

Yarovaya, L., J. Brzeszczynski, J. W. Goodell, B. M. Lucey, and C. K. Lau (2020). Rethinking financial contagion: Information transmission mechanism during the covid-19 pandemic. Available at SSRN http://dx.doi.org/10.2139/ssrn.3602973.

Yu, Y., W. Duan, and Q. Cao (2013). The impact of social and conventional media on firm equity value: A sentiment analysis approach. Decision support systems 55(4), 919-926.

Yuan, Y., X.-T. Zhuang, and Z.-Y. Liu (2012). Price-volume multifractal analysis and its application in chinese stock markets. Physica A: Statistical Mechanics and its Applications 391(12), 3484-3495.

Zhang, Y.-J. and Y.-M. Wei (2010). The crude oil market and the gold market: Evidence for cointegration, causality and price discovery. Resources Policy 35(3), 168-177. 
Figure 1: Cumulative number of confirmed cases and deaths since the beginning of the COVID-19 pandemic a) Worldwide

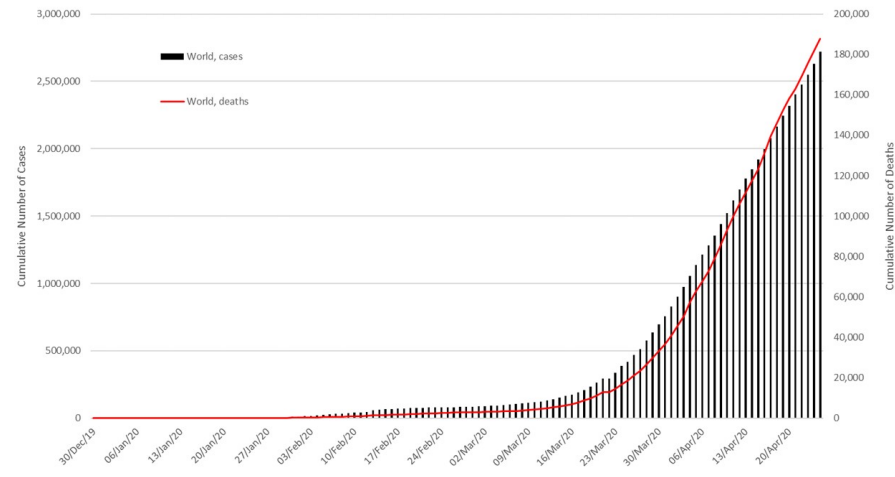

b) China

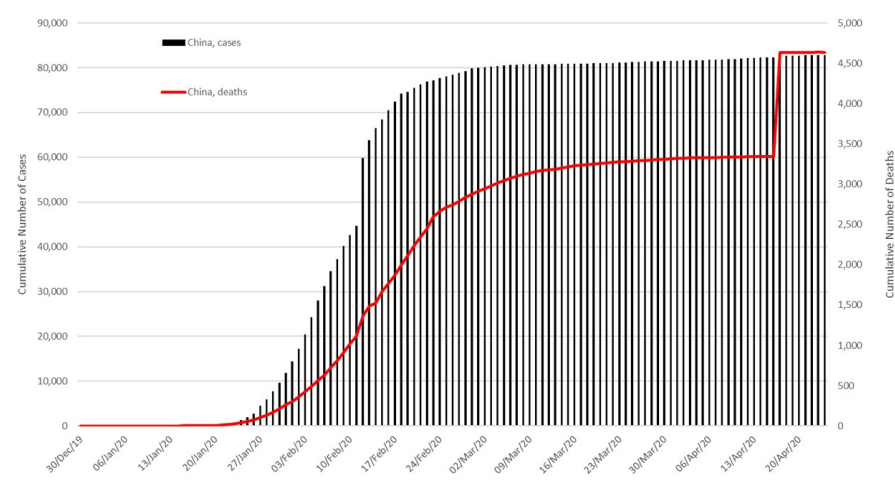

c) United States

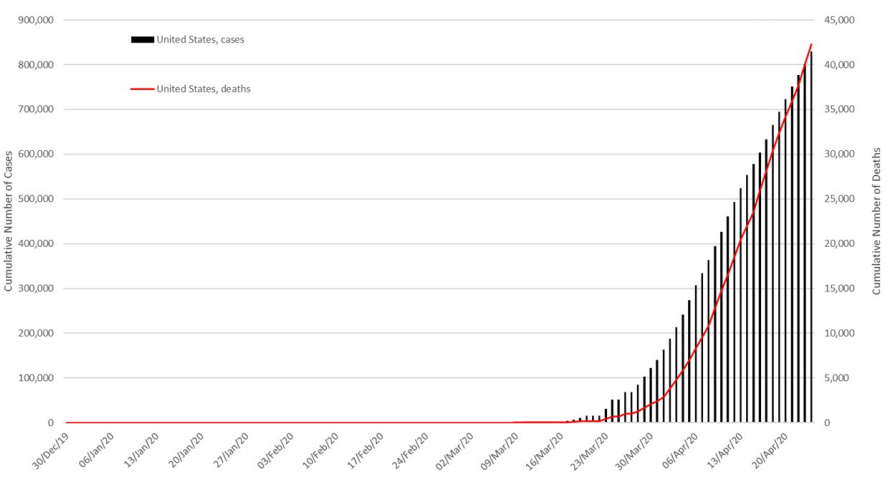

Note: The data was sourced from World Health Organization (WHO) and presented in ?. Data correct as of April 2020. 
Figure 2: Selected stock market performance, 5-minute performance

a) DJIA, United States

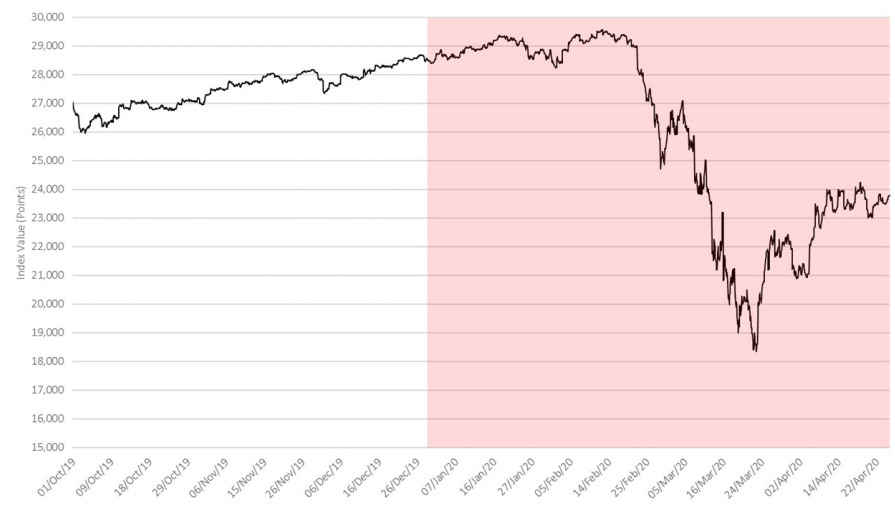

b) DAX, Germany

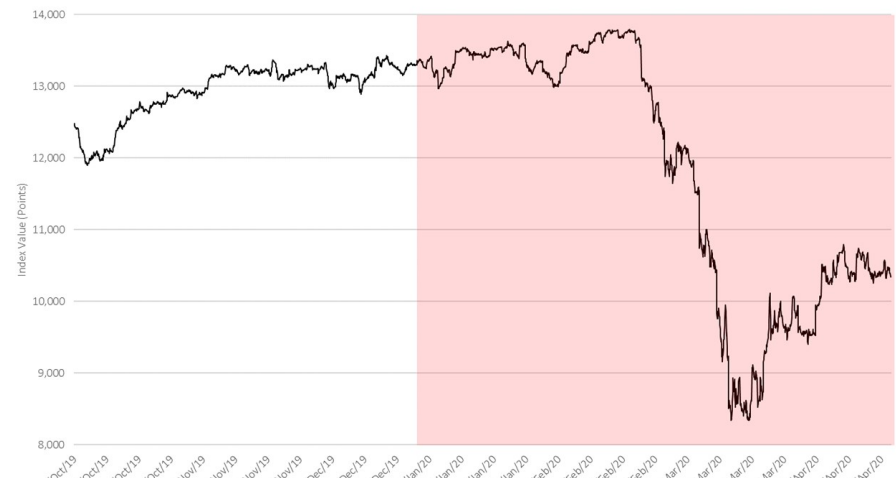

c) Shanghai, China

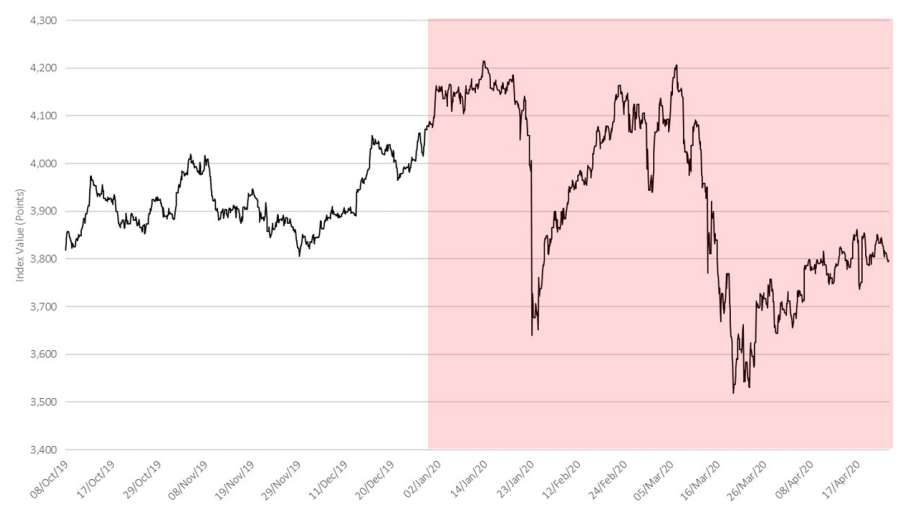

Note: The above data represents the 5-minute price levels of US, German and Chinese markets between the period October 2019 and April 2020. The shaded-area presents the period since 30 December 2019 when the WHO first identified the existence of Coronavirus through a public announcement. 
Figure 3: Price movements of Stock Indices, Commodities, Bitcoin and US dollar currency index

a) SSEA

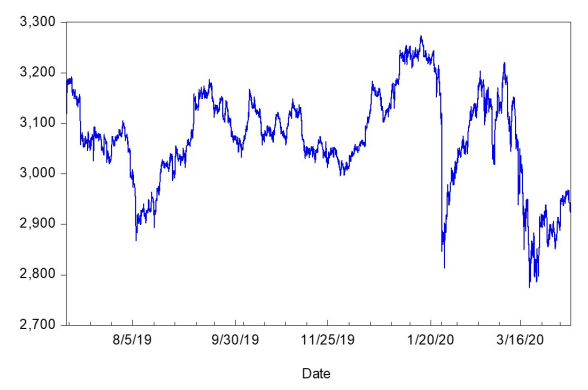

c) Oil

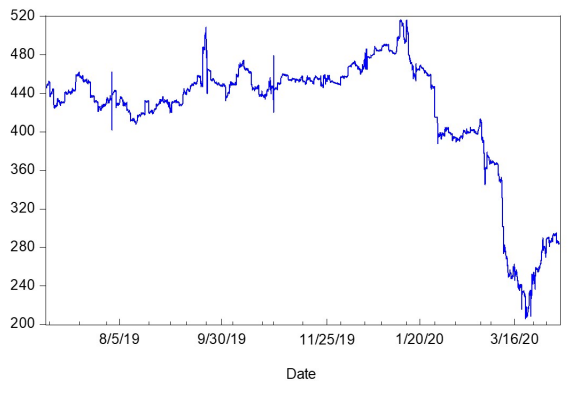

e) US Dollar

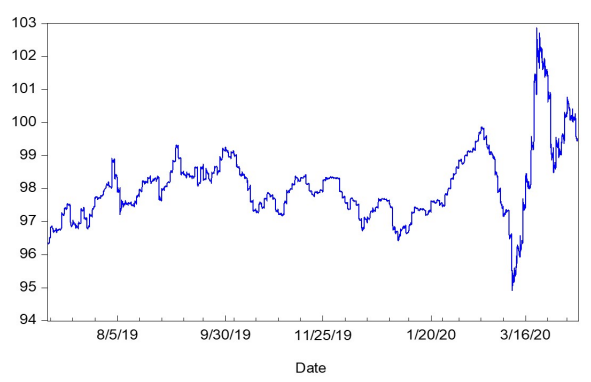

b) SSEB

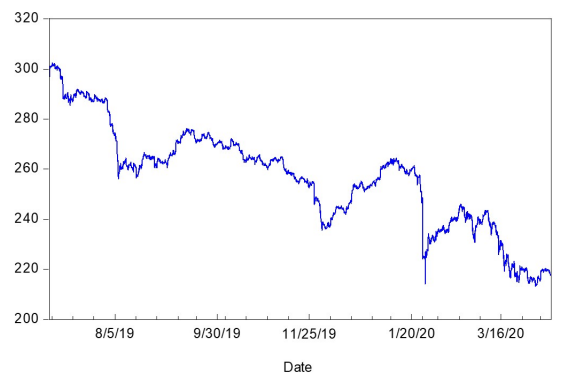

d) Bitcoin

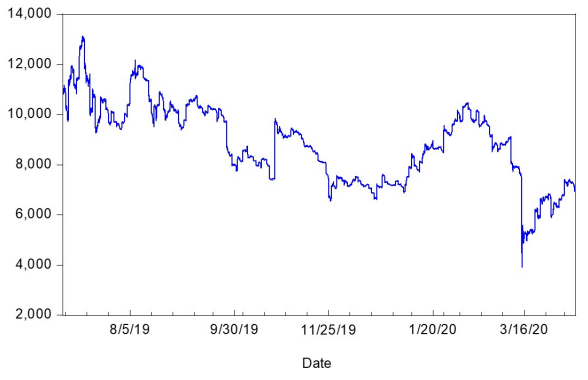

f) Corn

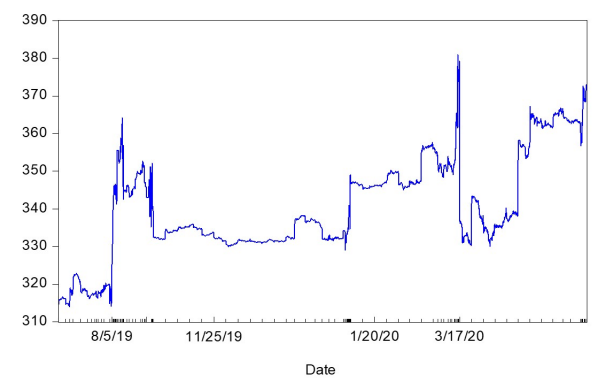

Note: SSEA is the Shanghai Stock Exchange A-share index. SSEB is the Shanghai Stock Exchange B-share index. Oil is the Chinese crude oil commodity futures traded in the Shanghai International Energy Exchange. Gold is the Chinese gold commodity futures. Corn is the Chinese corn commodity futures. Bitcoin is bitcoin traded in the Bitstamp cryptocurrency exchange. US dollar is the US dollar currency index. 
Figure 4: 30-min logarithmic ratios of time varying information share measures

a) SSEA \& Oil

SSEA - OI

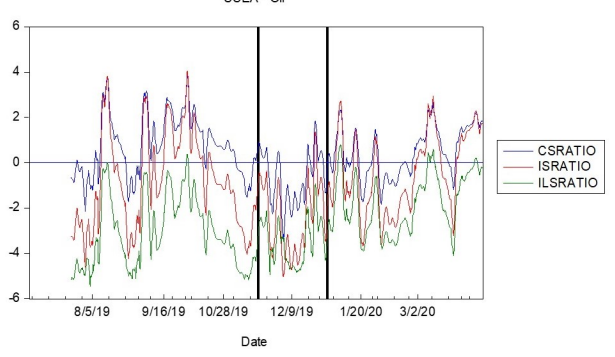

c) SSEA \& Bitcoin

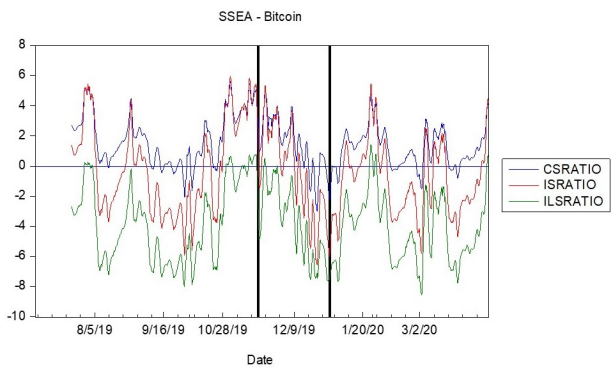

e) SSEA \& US Dollar

SSEA - US dollar

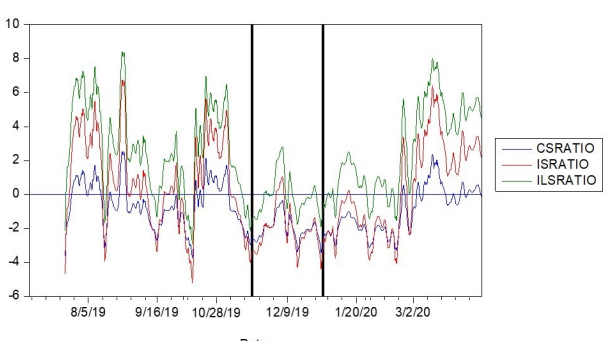

Date

g) SSEA \& Corn

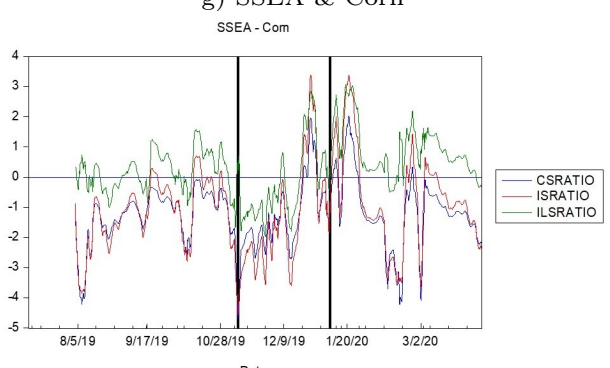

b) SSEB \& Oil

SSEB - OII

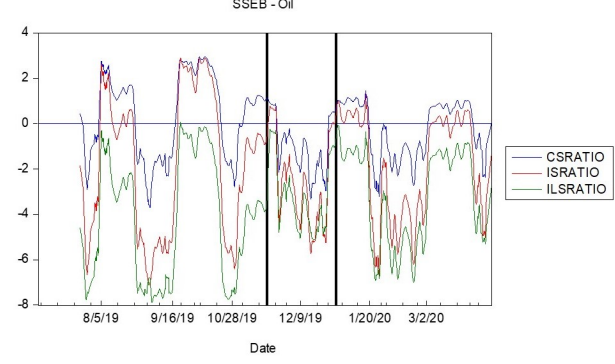

d) SSEB \& Bitcoin

SSEB - Bitco

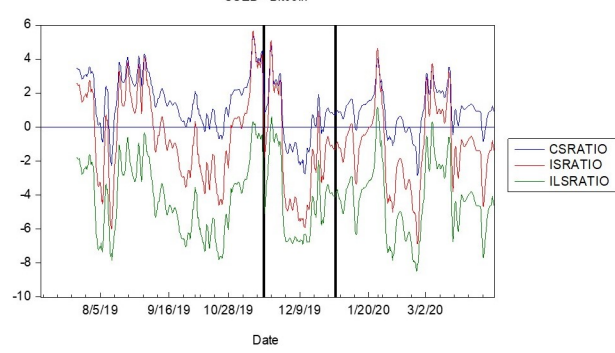

f) SSEB \& US Dollar

SSEB - US dollar

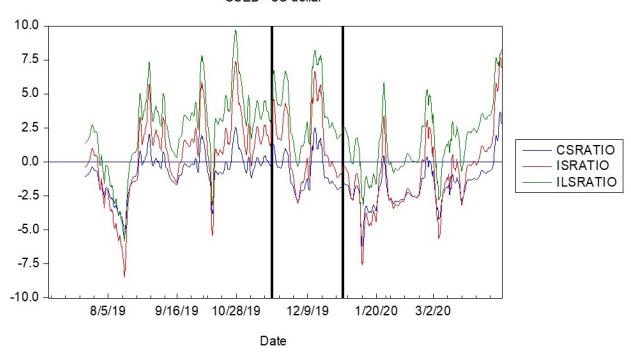

h) SSEB \& Corn

SSEB-Com

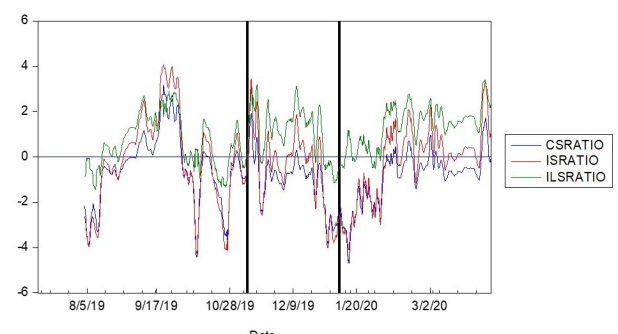

Date

Note: Logarithmic ratios of information share measures are calculated as the natural logarithms of ratios of time varying information share measures of Shanghai Stock Exchange A and B-share indices over the other five assets. CSRATIO, ratio of component share; ISRATIO, ratio of information share; ILSRATIO, ratio of information leadership share. The first vertical line refers to the ending time of November 16, 2019 and the second one refers to the ending time of December 30, 2019. 
Figure 5: 30-min time varying net volatility spillovers

a) SSEA, SSEB \& Oil

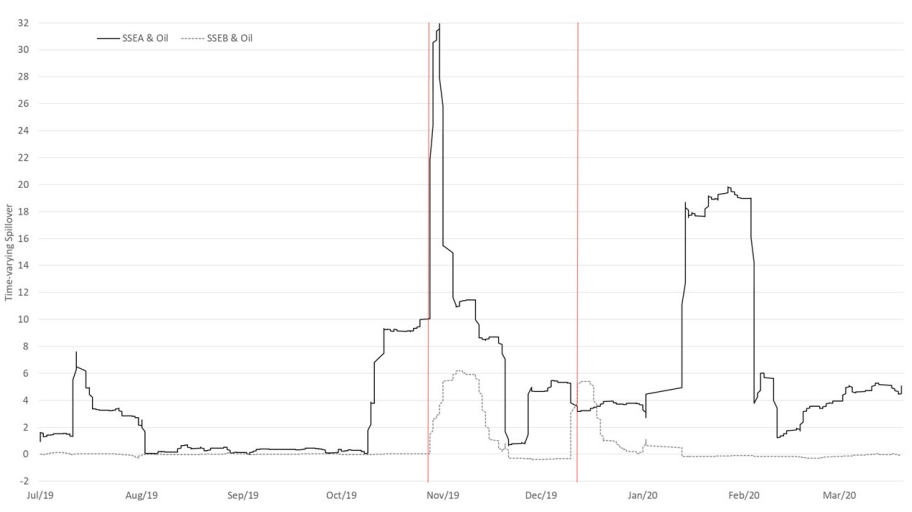

c) SSEA, SSEB \& US Dollar (\$)

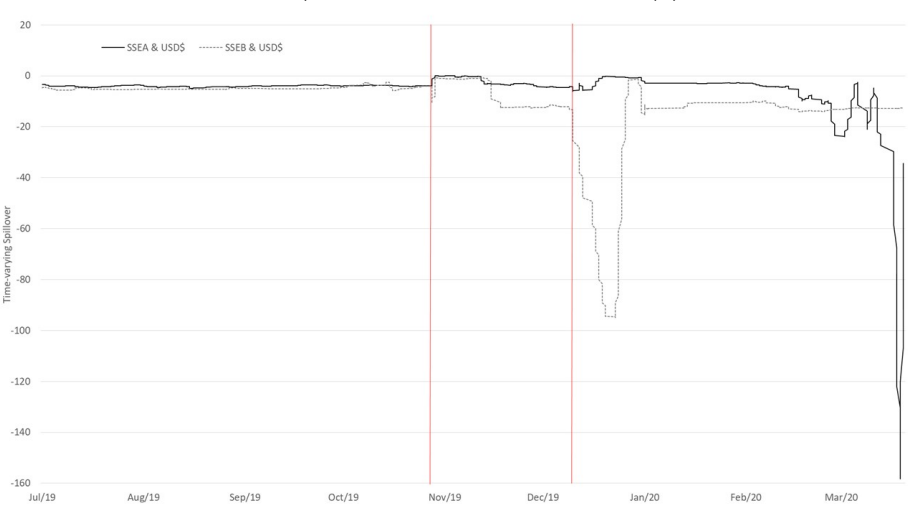

b) SSEA, SSEB \& Bitcoin

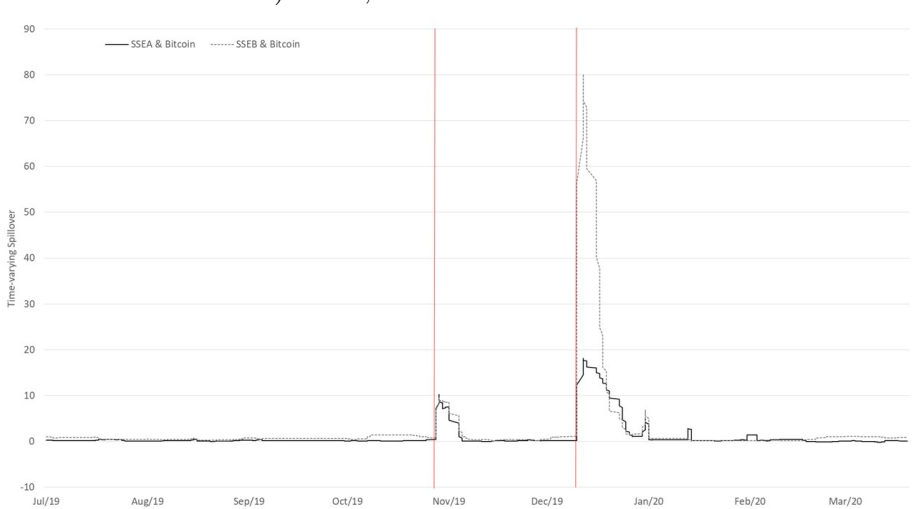

d) SSEA, SSEB \& Corn

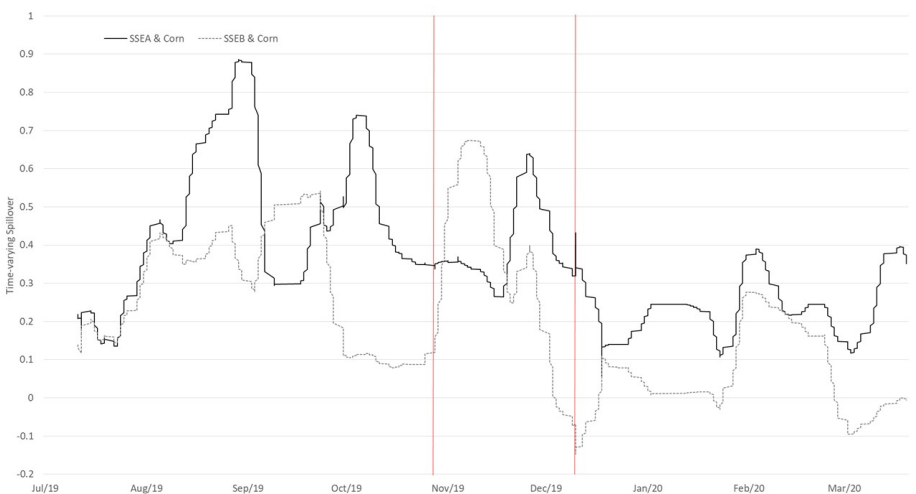

Note: Time varying net spillovers from the Shanghai Stock Exchange A- and B-share indices to other assets are calculated as the differences between absolute values of time varying spillovers from A- and B-share indices to other assets and absolute values of time varying spillovers of the other way around. The first vertical line refers to the ending time of November 16, 2019 and the second one refers to the ending time of December 30, 2019. SSEA, the Shanghai Stock Exchange A-share index; SSEB, the Shanghai Stock Exchange B-share index. 
Figure 6: 30-min time varying net skewness spillovers

a) SSEA, SSEB \& Oil

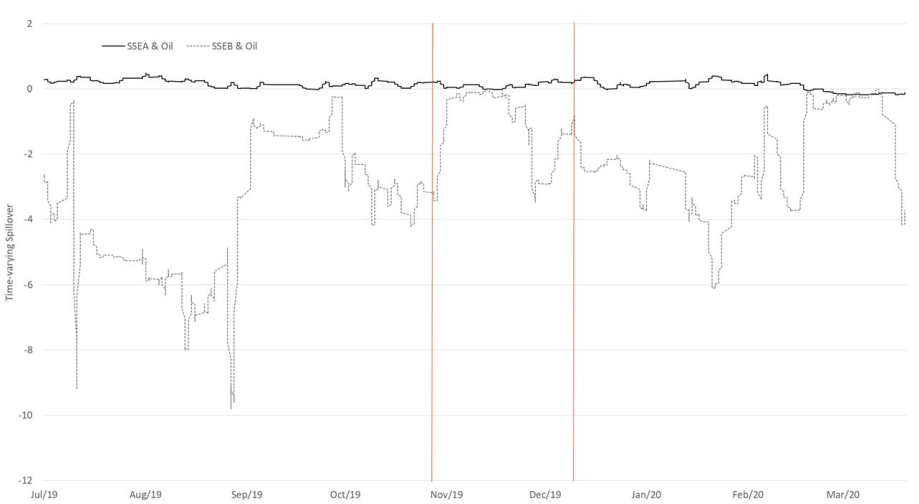

b

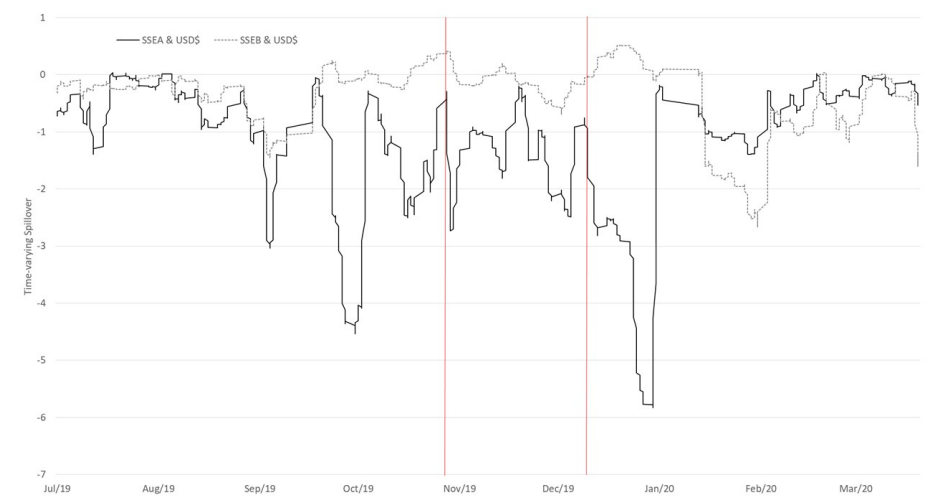

b) SSEA, SSEB \& Bitcoin

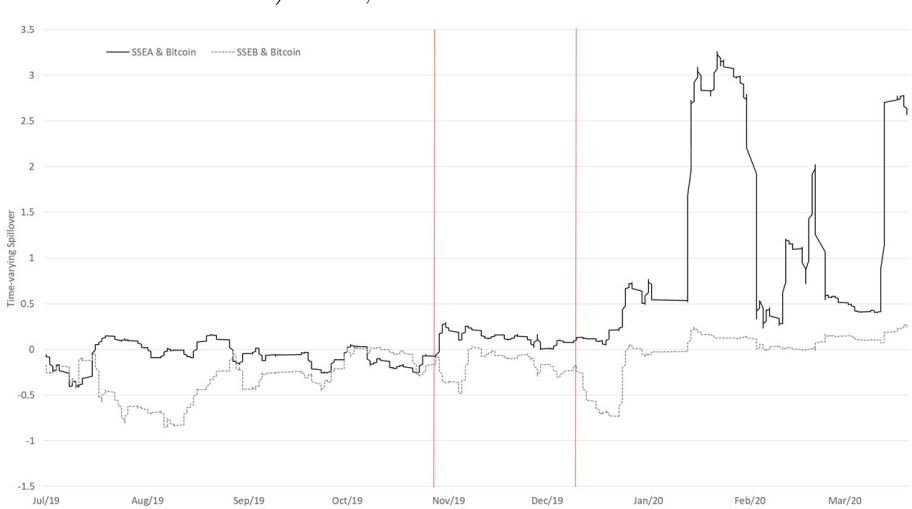

d) SSEA, SSEB \& Corn

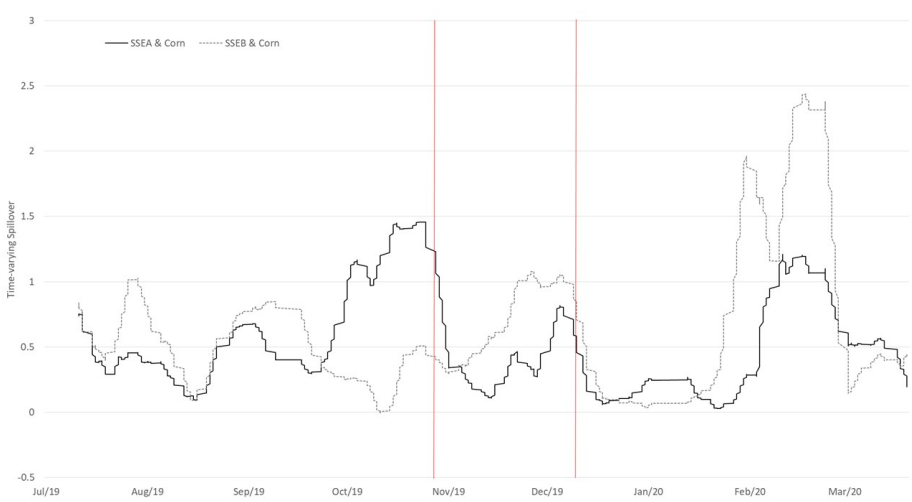

Note: Time varying net spillovers from the Shanghai Stock Exchange A- and B-share indices to other assets are calculated as the differences between absolute values of time varying spillovers from A- and B-share indices to other assets and absolute values of time varying spillovers of the other way around. The first vertical line refers to the ending time of November 16, 2019 and the second one refers to the ending time of December 30, 2019. SSEA, the Shanghai Stock Exchange A-share index; SSEB, the Shanghai Stock Exchange B-share index. 
Figure 7: 30-min time varying net kurtosis spillovers

a) SSEA, SSEB \& Oil

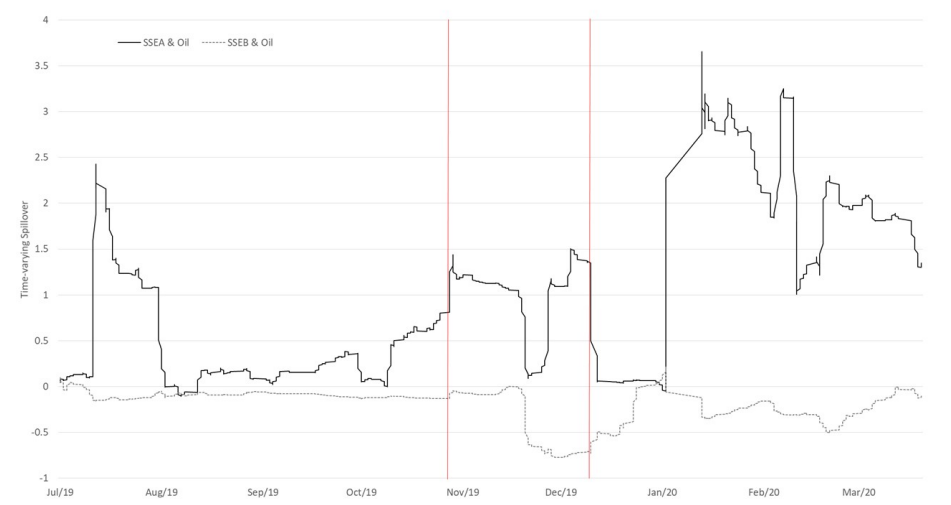

c) SSEA, SSEB \& US Dollar $(\$$ b) SSEA, SSEB \& Bitcoin
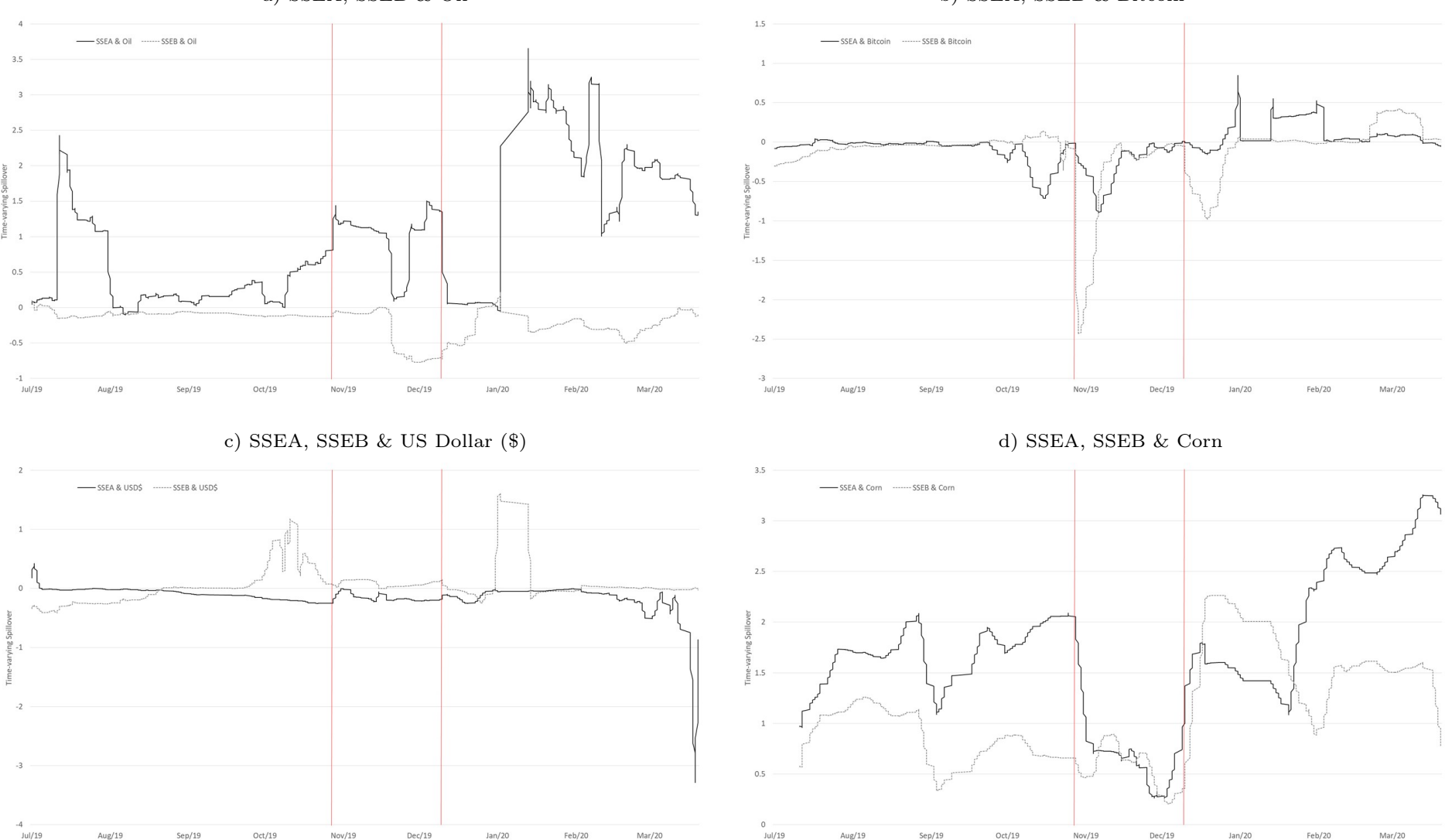

d) SSEA, SSEB \& Corn

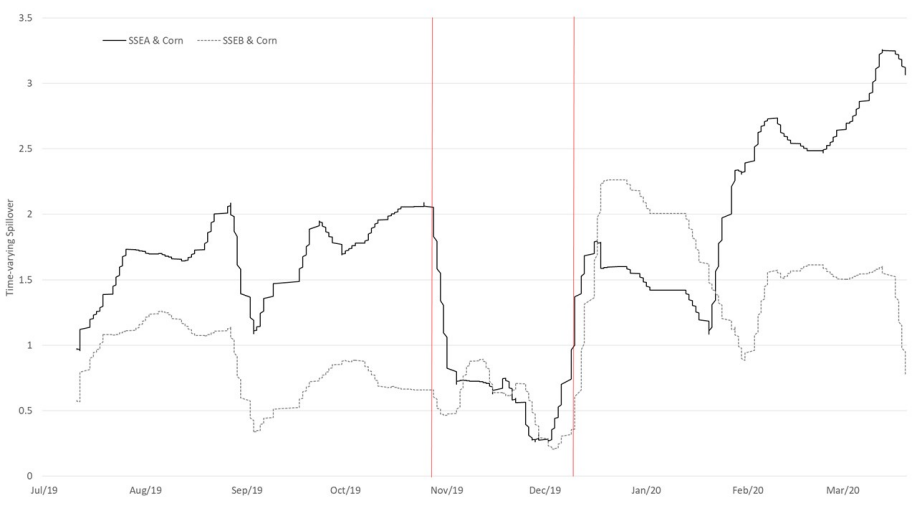

Note: Time varying net spillovers from the Shanghai Stock Exchange A- and B-share indices to other assets are calculated as the differences between absolute values of time varying spillovers from A- and B-share indices to other assets and absolute values of time varying spillovers of the other way around. The first vertical line refers to the ending time of November 16, 2019 and the second one refers to the ending time of December 30, 2019. SSEA, the Shanghai Stock Exchange A-share index; SSEB, the Shanghai Stock Exchange B-share index. 
Figure 8: Difference in time varying net volatility spillovers, SSEA less SSEB

a) Oil

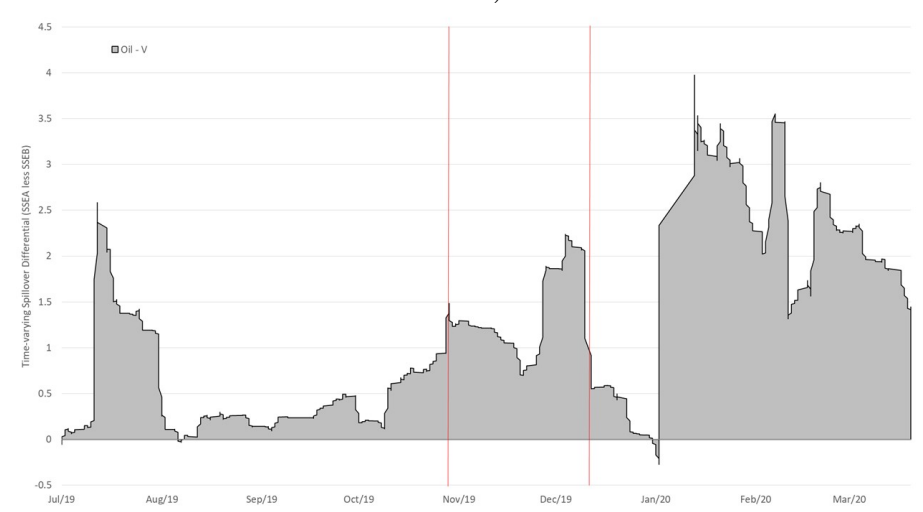

c) US Dollar (\$)
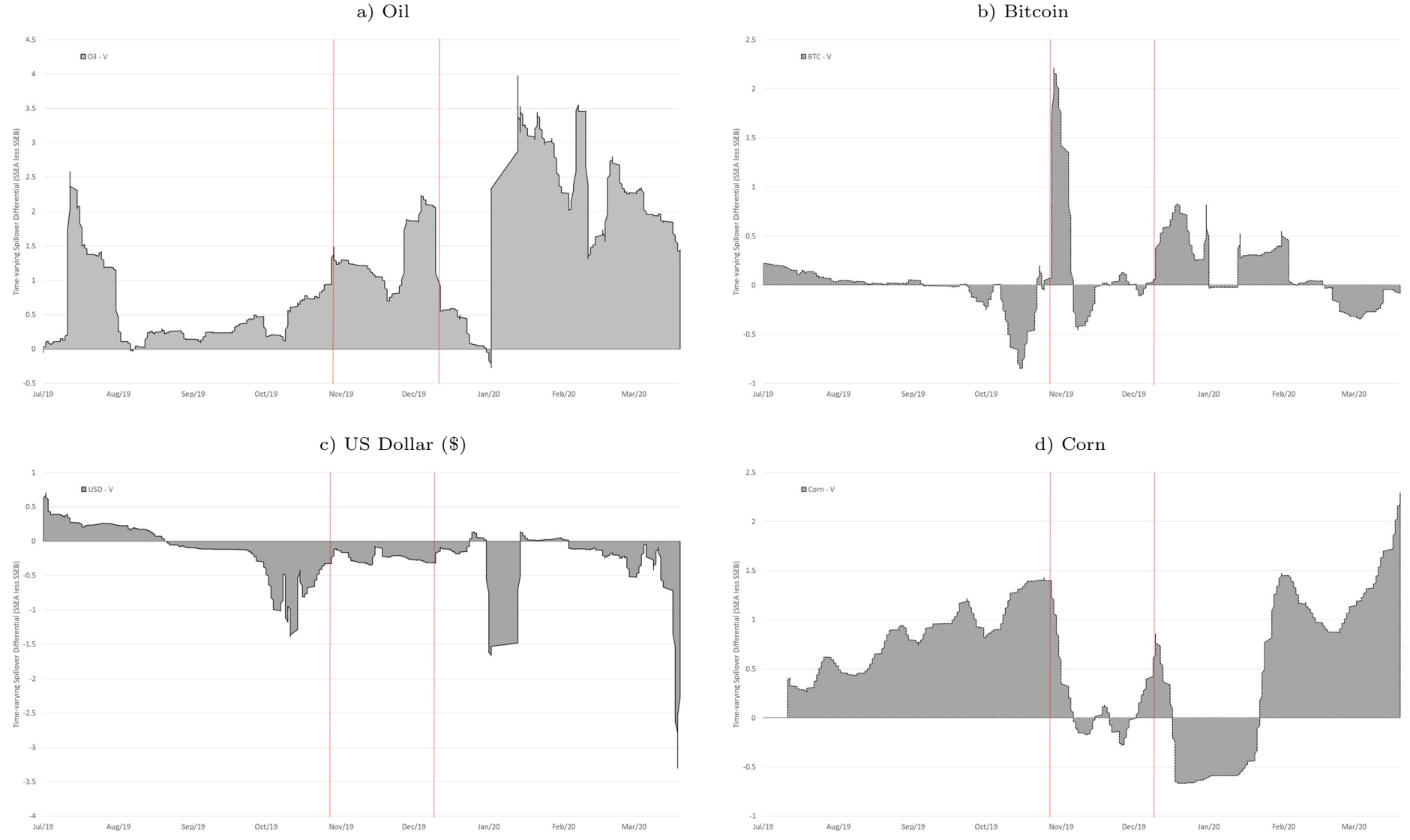

d) Corn

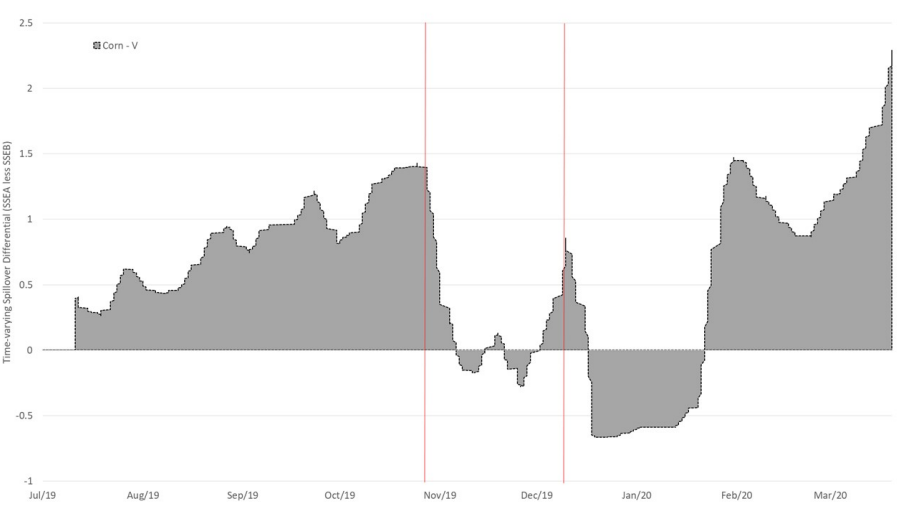

Note: Time varying net spillovers from the Shanghai Stock Exchange A- and B-share indices to other assets are calculated as the differences between absolute values of time varying spillovers from A- and B-share indices to other assets and absolute values of time varying spillovers of the other way around. The first vertical line refers to the ending time of November 16, 2019 and the second one refers to the ending time of December 30, 2019. SSEA, the Shanghai Stock Exchange A-share index; SSEB, the Shanghai Stock Exchange B-share index 
Figure 9: Difference in time varying net skewness spillovers, SSEA less SSEB

a) Oil

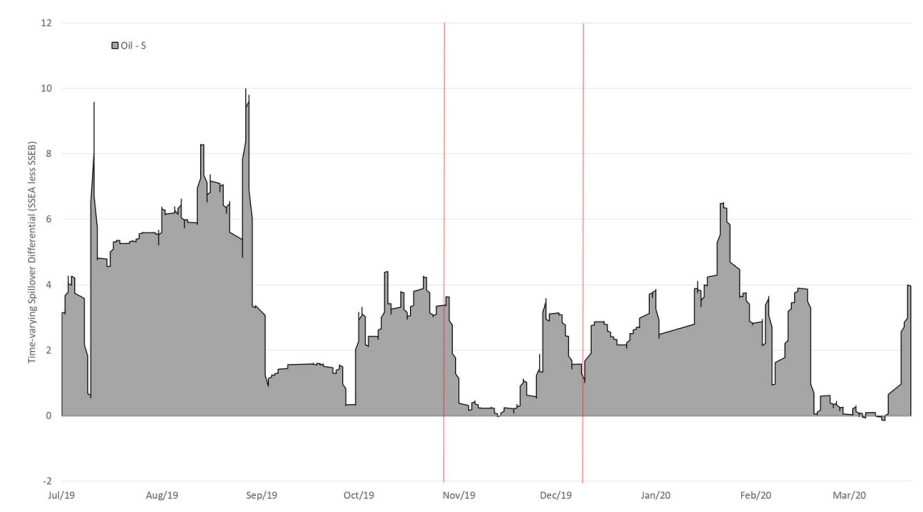

c) US Dollar $(\$)$

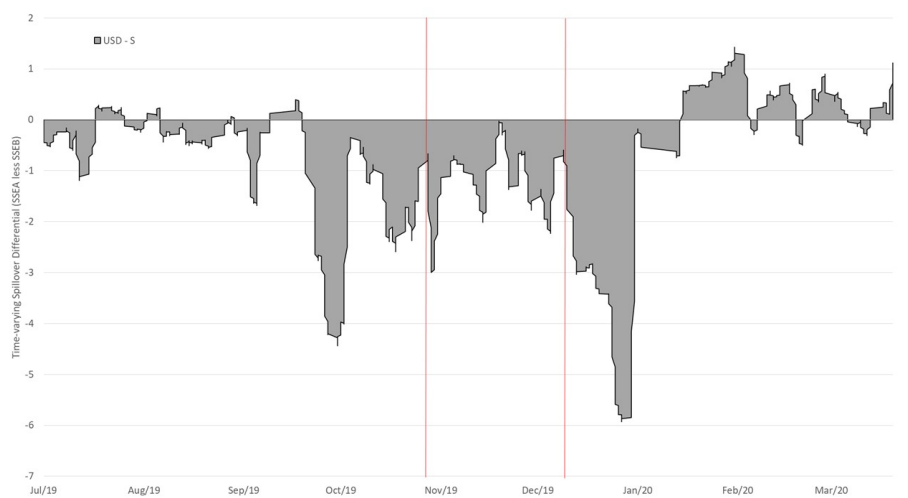

b) Bitcoin

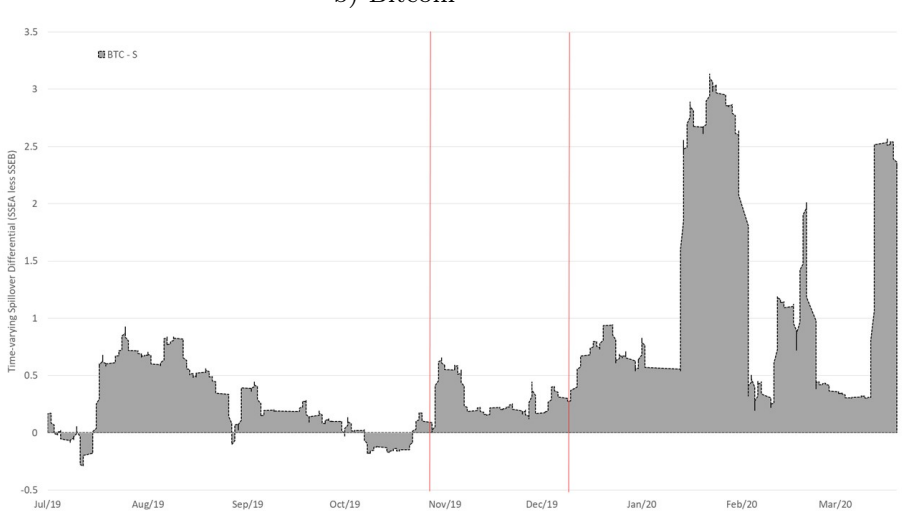

d) Corn

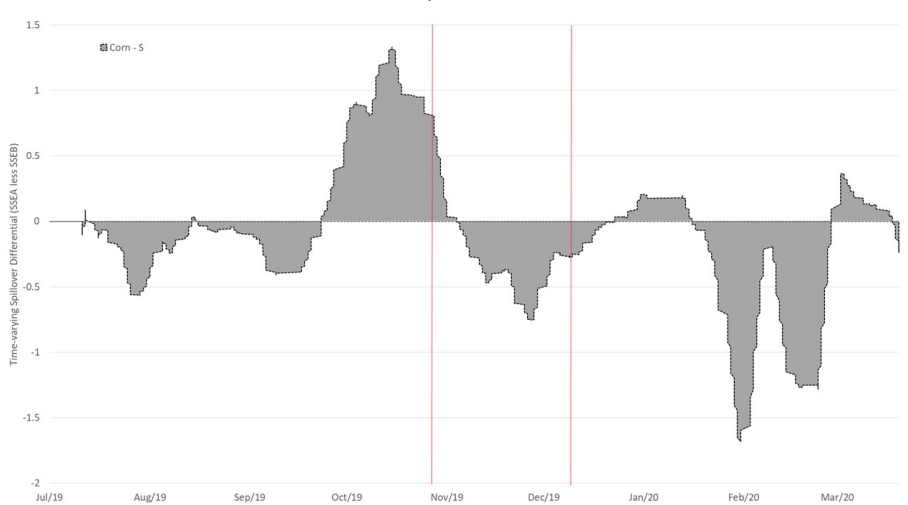

Note: Time varying net spillovers from the Shanghai Stock Exchange A- and B-share indices to other assets are calculated as the differences between absolute values of time varying spillovers from A- and B-share indices to other assets and absolute values of time varying spillovers of the other way around. The first vertical line refers to the ending time of November 16, 2019 and the second one refers to the ending time of December 30, 2019. SSEA, the Shanghai Stock Exchange A-share index; SSEB, the Shanghai Stock Exchange B-share index. 
Figure 10: Difference in time varying net kurtosis spillovers, SSEA less SSEB

a) Oil

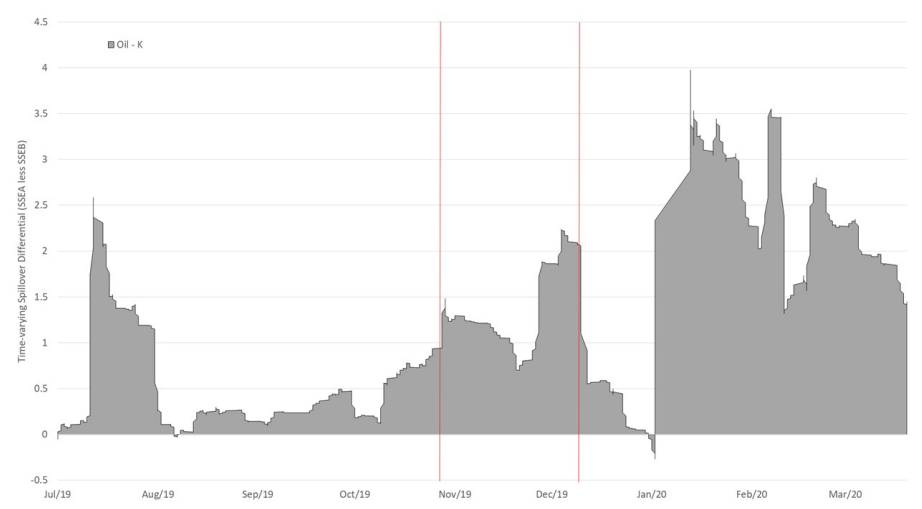

c) US Dollar (\$)

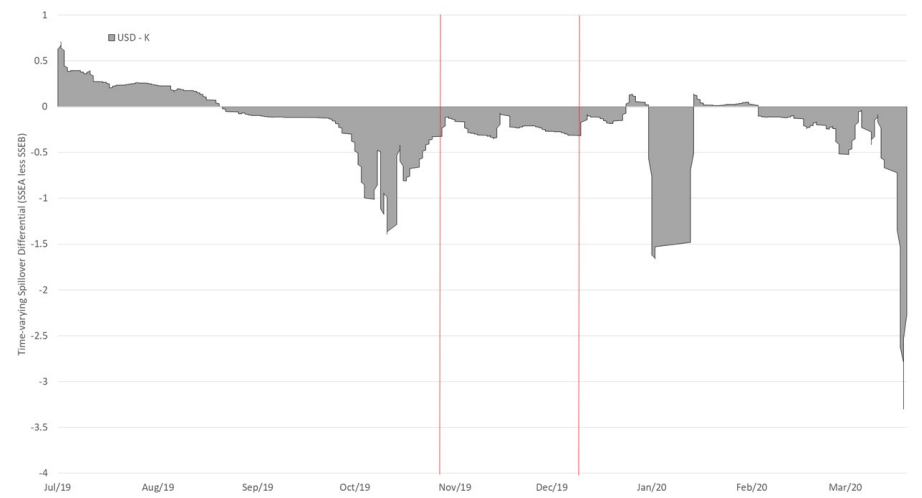

b) Bitcoin

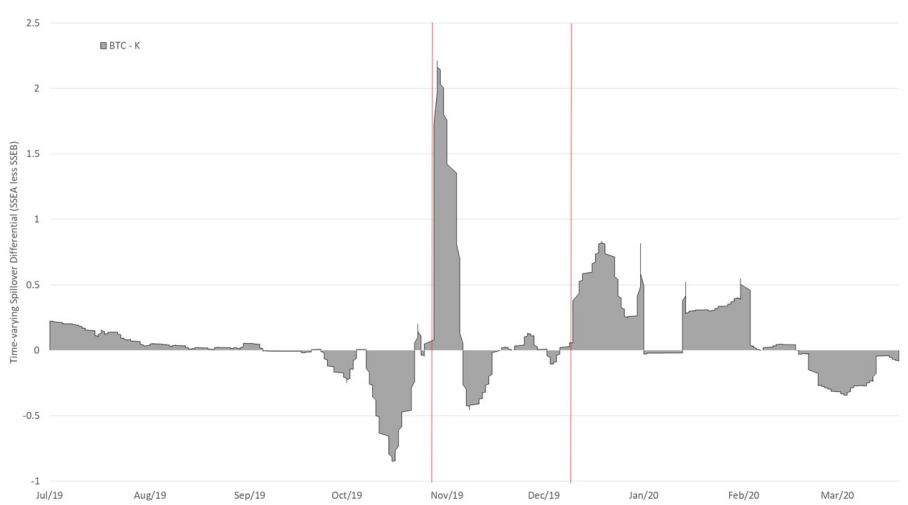

d) Corn

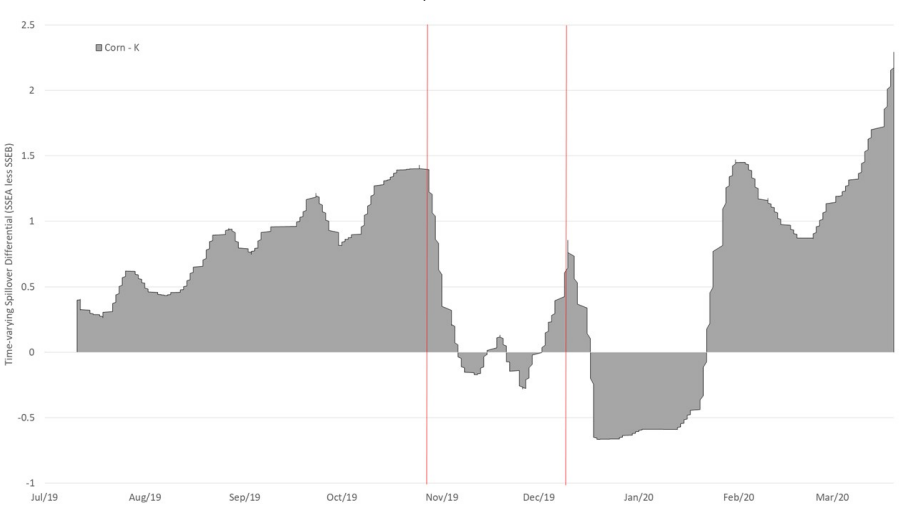

Note: Time varying net spillovers from the Shanghai Stock Exchange A- and B-share indices to other assets are calculated as the differences between absolute values of time varying spillovers from A- and B-share indices to other assets and absolute values of time varying spillovers of the other way around. The first vertical line refers to the ending time of November 16, 2019 and the second one refers to the ending time of December 30, 2019. SSEA, the Shanghai Stock Exchange A-share index; SSEB, the Shanghai Stock Exchange B-share index 
Table 1: Descriptive statistics of return series

\begin{tabular}{|c|c|c|c|c|c|c|}
\hline & SSEA & SSEB & Oil & Bitcoin & US dollar & Corn \\
\hline \multicolumn{7}{|c|}{ Full sample period: July 1, 2019 - April 10, 2020} \\
\hline Mean & $-4.73 \mathrm{E}-05$ & $-2.32 \mathrm{E}-04$ & $-3.98 \mathrm{E}-04$ & $-3.34 \mathrm{E}-04$ & $2.34 \mathrm{E}-05$ & $5.26 \mathrm{E}-05$ \\
\hline STD & 0.005 & 0.005 & 0.013 & 0.026 & 0.001 & 0.003 \\
\hline Maximum & 0.031 & 0.052 & 0.090 & 0.269 & 0.018 & 0.041 \\
\hline Minimum & -0.091 & -0.103 & -0.140 & -0.619 & -0.015 & -0.018 \\
\hline Skewness & -5.506 & -7.151 & -1.548 & -9.367 & 0.864 & 4.387 \\
\hline Kurtosis & 105.966 & 168.235 & 32.763 & 266.829 & 49.866 & 63.252 \\
\hline JB test & $5.97 \mathrm{E}+05^{* * *}$ & $1.53 \mathrm{E}+06^{* * *}$ & $4.30 \mathrm{E}+04^{* * *}$ & $3.89 \mathrm{E}+06^{* * *}$ & $1.22 \mathrm{E}+05^{* * *}$ & $1.60 \mathrm{E}+05^{* * *}$ \\
\hline \multicolumn{7}{|c|}{ P1: July 1, 2019 - November 16, 2019} \\
\hline Mean & $-3.90 \mathrm{E}-05$ & $-2.24 \mathrm{E}-04$ & $4.98 \mathrm{E}-06$ & $-3.63 \mathrm{E}-04$ & $2.84 \mathrm{E}-05$ & $-4.63 \mathrm{E}-05$ \\
\hline STD & 0.003 & 0.003 & 0.012 & 0.020 & 0.001 & 0.003 \\
\hline Maximum & 0.015 & 0.010 & 0.090 & 0.269 & 0.008 & 0.021 \\
\hline Minimum & -0.017 & -0.020 & -0.140 & -0.128 & -0.007 & -0.018 \\
\hline Skewness & -0.598 & -1.242 & -1.882 & 3.589 & -0.508 & 0.626 \\
\hline Kurtosis & 8.774 & 10.722 & 50.522 & 63.454 & 19.108 & 20.681 \\
\hline JB test & $951.791^{* * *}$ & $1801.367^{* * *}$ & $5.50 \mathrm{E}+04^{* * *}$ & $1.01 \mathrm{E}+05^{* * *}$ & $7131.146^{* * *}$ & $6231.389^{* * *}$ \\
\hline \multicolumn{7}{|c|}{ P2: November 17, 2019 - December 30, 2019} \\
\hline Mean & $2.11 \mathrm{E}-04$ & $-2.86 \mathrm{E}-06$ & $4.62 \mathrm{E}-04$ & $-7.03 \mathrm{E}-04$ & $-6.26 \mathrm{E}-05$ & $-2.51 \mathrm{E}-05$ \\
\hline STD & 0.002 & 0.003 & 0.007 & 0.014 & 0.001 & 0.002 \\
\hline Maximum & 0.009 & 0.009 & 0.039 & 0.079 & 0.004 & 0.011 \\
\hline Minimum & -0.010 & -0.029 & -0.033 & -0.104 & -0.006 & -0.007 \\
\hline Skewness & 0.327 & -3.116 & 0.613 & 0.169 & -2.266 & 1.333 \\
\hline Kurtosis & 5.222 & 27.237 & 14.207 & 27.082 & 21.234 & 16.746 \\
\hline JB test & $48.518^{* * *}$ & $5662.304^{* * *}$ & $969.061^{* * *}$ & $5244.571^{* * *}$ & $3191.956^{* * *}$ & $1772.635^{* * *}$ \\
\hline \multicolumn{7}{|c|}{ P3: December 31, 2019 - April 10, 2020 } \\
\hline Mean & $-1.80 \mathrm{E}-04$ & $-3.50 \mathrm{E}-04$ & -0.001 & $-1.20 \mathrm{E}-04$ & $5.67 \mathrm{E}-05$ & $2.40 \mathrm{E}-04$ \\
\hline STD & 0.007 & 0.007 & 0.015 & 0.035 & 0.002 & 0.004 \\
\hline Maximum & 0.031 & 0.052 & 0.073 & 0.136 & 0.018 & 0.041 \\
\hline Minimum & -0.091 & -0.103 & -0.095 & -0.619 & -0.015 & -0.013 \\
\hline Skewness & -4.798 & -6.025 & -1.146 & -11.517 & 0.976 & 5.545 \\
\hline Kurtosis & 63.035 & 98.665 & 14.001 & 209.524 & 32.854 & 58.047 \\
\hline JB test & $7.12 \mathrm{E}+04^{* * *}$ & $1.79 \mathrm{E}+05^{* * *}$ & $2046.612^{* * *}$ & $8.31 \mathrm{E}+05^{* * *}$ & $1.72 \mathrm{E}+04^{* * *}$ & $4.47 \mathrm{E}+04^{* * *}$ \\
\hline
\end{tabular}

Note: Returns are calculated by taking the first differences of logarithmic prices. SSEA is the Shanghai Stock Exchange A-share index; SSEB is the Shanghai Stock Exchange B-share index. Oil, the Chinese crude oil commodity futures traded in the Shanghai International Energy Exchange; Gold, the Chinese gold commodity futures; Corn, the Chinese corn commodity futures; Bitcoin, bitcoin traded in the Bitstamp cryptocurrency exchange; US dollar, US dollar currency index. STD denotes standard deviation. JB test is the Jarque-Bera normality test. E stands for scientific notation. $* * *$ represents significance at the $1 \%$ level. 
Table 2: SSEA Two-state regime switching model (Estimation from data at 30-min intervals)

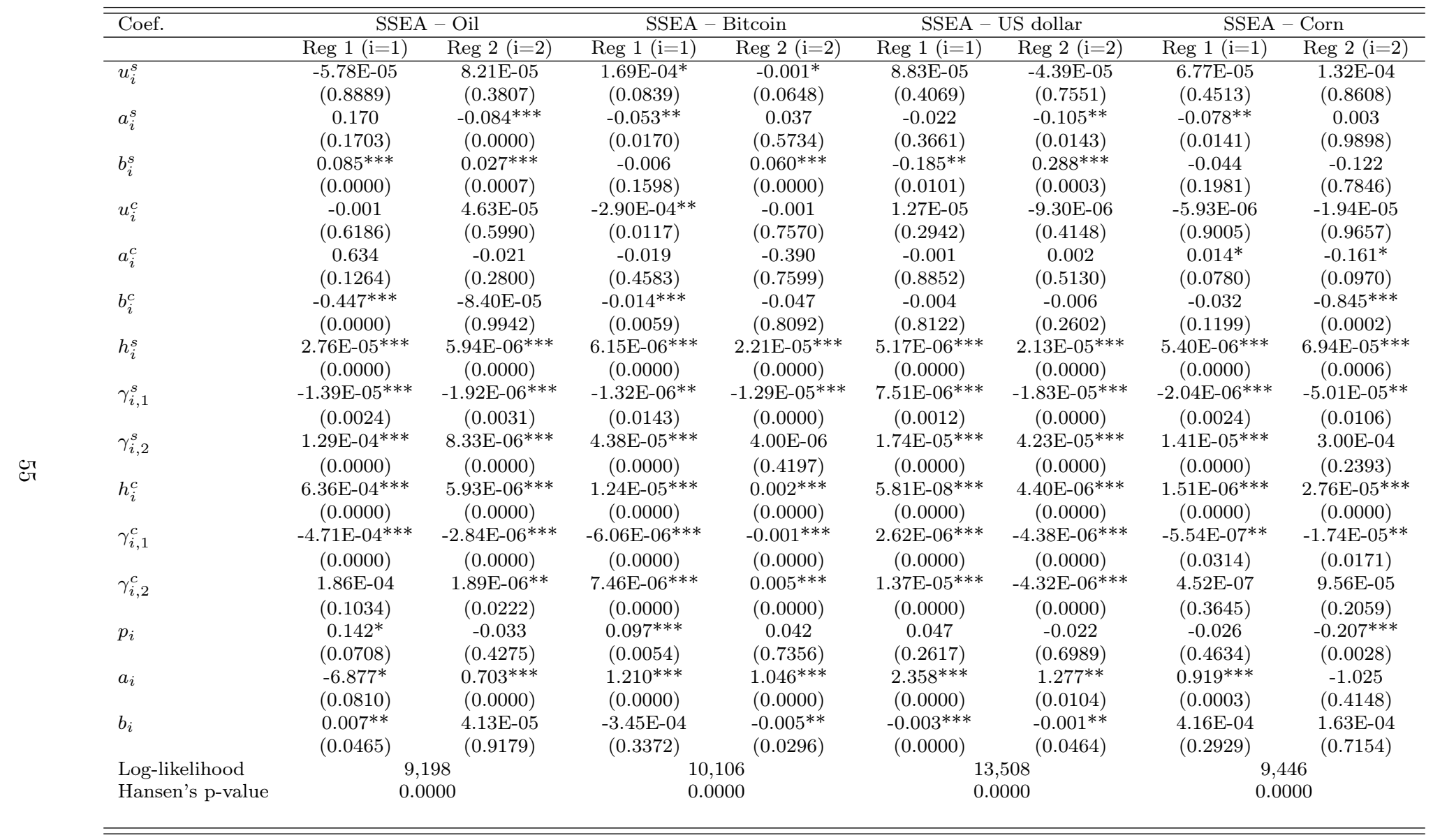

Note: This table reports the estimation result of the two-state regime switching model. Estimation is done for five sample pairs consisting of one Shanghai Stock Exchange A- or B-share index and one commodity asset and results are separately shown. Coef. denotes model coefficients. SSEA index is the Shangha Stock Exchange A-share index; SSEB index is the Shanghai Stock Exchange B-share index. Hansen (1992)'s standardized likelihood ratio test is employed to test the existence of regimes and associated p-value of test statistic is shown. E stands for scientific notation. Figures in parentheses are $\mathrm{p}$ values of significance check. ${ }^{* * *},{ }^{* *}$ and $*$ represent significance at the $1 \%, 5 \%$ and $10 \%$, respectively. 
Table 3: SSEB Two-state regime switching model (Estimation from data at 30-min intervals)

\begin{tabular}{|c|c|c|c|c|c|c|c|c|}
\hline \multirow[t]{2}{*}{ Coef. } & \multicolumn{2}{|c|}{ SSEB - Oil } & \multicolumn{2}{|c|}{ SSEB - Bitcoin } & \multicolumn{2}{|c|}{ SSEB - US dollar } & \multicolumn{2}{|c|}{ SSEB - Corn } \\
\hline & $\operatorname{Reg} 1(\mathrm{i}=1)$ & $\operatorname{Reg} 2(\mathrm{i}=2)$ & $\operatorname{Reg} 1(\mathrm{i}=1)$ & Reg $2(\mathrm{i}=2)$ & $\operatorname{Reg} 1(\mathrm{i}=1)$ & $\operatorname{Reg} 2(\mathrm{i}=2)$ & $\operatorname{Reg} 1(\mathrm{i}=1)$ & $\operatorname{Reg} 2(i=2)$ \\
\hline$u_{i}^{s}$ & $\begin{array}{l}-0.001^{*} \\
(0.0825)\end{array}$ & $\begin{array}{c}-1.60 \mathrm{E}-06 \\
(0.9851)\end{array}$ & $\begin{array}{c}-1.60 \mathrm{E}-06 \\
(0.9842)\end{array}$ & $\begin{array}{l}-0.001^{*} \\
(0.0593)\end{array}$ & $\begin{array}{c}-9.62 \mathrm{E}-05 \\
(0.2761)\end{array}$ & $\begin{array}{c}-3.57 \mathrm{E}-05 \\
(0.7657)\end{array}$ & $\begin{array}{l}-0.001^{*} \\
(0.0920)\end{array}$ & $\begin{array}{c}-4.26 \mathrm{E}-05 \\
(0.6044)\end{array}$ \\
\hline$a_{i}^{s}$ & $\begin{array}{c}-0.012 \\
(0.7967)\end{array}$ & $\begin{array}{l}0.049^{* *} \\
(0.0150)\end{array}$ & $\begin{array}{c}0.059 \\
(0.1603)\end{array}$ & $\begin{array}{c}0.200^{*} \\
(0.0998)\end{array}$ & $\begin{array}{c}0.082^{* * *} \\
(0.0012)\end{array}$ & $\begin{array}{c}0.115^{* * *} \\
(0.0000)\end{array}$ & $\begin{array}{c}0.018 \\
(0.9262)\end{array}$ & $\begin{array}{c}0.036 \\
(0.2464)\end{array}$ \\
\hline$b_{i}^{s}$ & $\begin{array}{c}0.078^{* * *} * \\
(0.0000)\end{array}$ & $\begin{array}{c}0.015 \\
(0.1197)\end{array}$ & $\begin{array}{l}-0.002 \\
(0.5896)\end{array}$ & $\begin{array}{c}0.033^{* * *} \\
(0.0004)\end{array}$ & $\begin{array}{c}-3.27 \mathrm{E}-04 \\
(0.9974)\end{array}$ & $\begin{array}{c}0.113 \\
(0.1588)\end{array}$ & $\begin{array}{l}-0.377 \\
(0.4021)\end{array}$ & $\begin{array}{c}0.012 \\
(0.5540)\end{array}$ \\
\hline$u_{i}^{c}$ & $\begin{array}{c}-1.14 \mathrm{E}-04 \\
(0.4633)\end{array}$ & $\begin{array}{c}6.98 \mathrm{E}-05 \\
(0.4671)\end{array}$ & $\begin{array}{c}-2.97 \mathrm{E}-04^{* *} \\
(0.0103)\end{array}$ & $\begin{array}{l}-0.001 \\
(0.7480)\end{array}$ & $\begin{array}{l}1.08 \mathrm{E}-05 \\
(0.3697)\end{array}$ & $\begin{array}{c}-1.12 \mathrm{E}-05 \\
(0.3955)\end{array}$ & $\begin{array}{c}-1.51 \mathrm{E}-04 \\
(0.7055)\end{array}$ & $\begin{array}{c}-1.93 \mathrm{E}-05 \\
(0.6661)\end{array}$ \\
\hline$a_{i}^{c}$ & $\begin{array}{c}0.017 \\
(0.2274)\end{array}$ & $\begin{array}{c}0.006 \\
(0.7947)\end{array}$ & $\begin{array}{c}-0.002 \\
(0.9210)\end{array}$ & $\begin{array}{c}0.055 \\
(0.9314)\end{array}$ & $\begin{array}{c}-0.001 \\
(0.7716)\end{array}$ & $\begin{array}{c}0.001 \\
(0.7369)\end{array}$ & $\begin{array}{c}-0.181^{* *} \\
(0.0447)\end{array}$ & $\begin{array}{c}0.007 \\
(0.3980)\end{array}$ \\
\hline$b_{i}^{c}$ & $\begin{array}{c}-0.023^{* * *} \\
(0.0066)\end{array}$ & $\begin{array}{l}-0.006 \\
(0.7200)\end{array}$ & $\begin{array}{c}-0.010 \\
(0.1868)\end{array}$ & $\begin{array}{c}-0.049 \\
(0.6056)\end{array}$ & $\begin{array}{c}-0.007 \\
(0.5884)\end{array}$ & $\begin{array}{c}0.010 \\
(0.2372)\end{array}$ & $\begin{array}{c}-0.947^{* * * *} \\
(0.0000)\end{array}$ & $\begin{array}{l}-0.039^{*} \\
(0.0527)\end{array}$ \\
\hline$h_{i}^{s}$ & $\begin{array}{c}2.73 \mathrm{E}-05^{* * * *} \\
(0.0000)\end{array}$ & $\begin{array}{c}3.93 \mathrm{E}-06^{* * * *} \\
(0.0000)\end{array}$ & $\begin{array}{c}3.46 \mathrm{E}-06^{* * * *} \\
(0.0000)\end{array}$ & $\begin{array}{c}2.07 \mathrm{E}-05^{* * *} \\
(0.0000)\end{array}$ & $\begin{array}{c}2.85 \mathrm{E}-06^{* * *} \\
(0.0000)\end{array}$ & $\begin{array}{c}1.89 \mathrm{E}-05^{* * *} \\
(0.0000)\end{array}$ & $\begin{array}{c}4.78 \mathrm{E}-05^{* * *} \\
(0.0000)\end{array}$ & $\begin{array}{c}3.52 \mathrm{E}-06^{* * *} \\
(0.0000)\end{array}$ \\
\hline$\gamma_{i, 1}^{s}$ & $\begin{array}{c}2.46 \mathrm{E}-05^{* * *} \\
(0.0000)\end{array}$ & $\begin{array}{c}-9.29 \mathrm{E}-07^{*} \\
(0.0641)\end{array}$ & $\begin{array}{c}2.91 \mathrm{E}-07 \\
(0.7406)\end{array}$ & $\begin{array}{c}1.71 \mathrm{E}-05 \\
(0.3359)\end{array}$ & $\begin{array}{c}4.10 \mathrm{E}-05^{* * *} \\
(0.0000)\end{array}$ & $\begin{array}{c}-1.52 \mathrm{E}-05^{* * *} \\
(0.0000)\end{array}$ & $\begin{array}{c}1.46 \mathrm{E}-05 \\
(0.6505)\end{array}$ & $\begin{array}{c}3.98 \mathrm{E}-07 \\
(0.6448)\end{array}$ \\
\hline$\gamma_{i, 2}^{s}$ & $\begin{array}{c}6.28 \mathrm{E}-05^{* * *} \\
(0.0000)\end{array}$ & $\begin{array}{c}1.87 \mathrm{E}-05^{* * *} \\
(0.0000)\end{array}$ & $\begin{array}{c}5.49 \mathrm{E}-05^{*} \\
(0.0725)\end{array}$ & $\begin{array}{c}2.63 \mathrm{E}-06 \\
(0.7131)\end{array}$ & $\begin{array}{c}2.12 \mathrm{E}-04^{* * *} \\
(0.0000)\end{array}$ & $\begin{array}{c}-5.99 \mathrm{E}-06^{* * *} \\
(0.0000)\end{array}$ & $\begin{array}{c}0.001 \\
(0.1599)\end{array}$ & $\begin{array}{c}1.43 \mathrm{E}-05^{* * *} \\
(0.0000)\end{array}$ \\
\hline$h_{i}^{c}$ & $\begin{array}{l}7.16 \mathrm{E}-04^{* * * *} \\
(0.0000)\end{array}$ & $\begin{array}{c}5.74 \mathrm{E}-06^{* * *} \\
(0.0000)\end{array}$ & $\begin{array}{c}1.18 \mathrm{E}-05^{* * *} \\
(0.0000)\end{array}$ & $\begin{array}{c}0.002^{* * *} \\
(0.0053)\end{array}$ & $\begin{array}{c}5.23 \mathrm{E}-08^{* * *} \\
(0.0000)\end{array}$ & $\begin{array}{c}3.73 \mathrm{E}-06^{* * *} \\
(0.0000)\end{array}$ & $\begin{array}{c}2.29 \mathrm{E}-05^{* * *} \\
(0.0000)\end{array}$ & $\begin{array}{c}1.48 \mathrm{E}-06^{* * * *} \\
(0.0000)\end{array}$ \\
\hline$\gamma_{i, 1}^{c}$ & $\begin{array}{c}-5.62 \mathrm{E}-04^{* * *} \\
(0.0000)\end{array}$ & $\begin{array}{c}-3.55 \mathrm{E}-06^{* * *} \\
(0.0000)\end{array}$ & $\begin{array}{c}-5.18 \mathrm{E}-06^{* * *} \\
(0.0074)\end{array}$ & $\begin{array}{c}-8.10 \mathrm{E}-04 \\
(0.2585)\end{array}$ & $\begin{array}{c}3.78 \mathrm{E}-06^{* * *} \\
(0.0000)\end{array}$ & $\begin{array}{c}-3.70 \mathrm{E}-06^{* * *} \\
(0.0000)\end{array}$ & $\begin{array}{c}-1.16 \mathrm{E}-05^{*} \\
(0.0991)\end{array}$ & $\begin{array}{c}-5.24 \mathrm{E}-07^{* *} \\
\quad(0.0323)\end{array}$ \\
\hline$\gamma_{i, 2}^{c}$ & $\begin{array}{c}-7.13 \mathrm{E}-04^{* * *} \\
(0.0000)\end{array}$ & $\begin{array}{l}4.54 \mathrm{E}-04^{* * *} \\
\quad(0.0000)\end{array}$ & $\begin{array}{l}5.16 \mathrm{E}-06 \\
(0.1906)\end{array}$ & $\begin{array}{c}0.005 \\
(0.3756)\end{array}$ & $\begin{array}{l}2.15 \mathrm{E}-05^{* * *} \\
(0.0000)\end{array}$ & $\begin{array}{c}-3.51 \mathrm{E}-06^{* * *} \\
(0.0000)\end{array}$ & $\begin{array}{c}1.53 \mathrm{E}-04^{*} \\
(0.0954)\end{array}$ & $\begin{array}{r}6.57 \mathrm{E}-07 \\
(0.1670)\end{array}$ \\
\hline$p_{i}$ & $\begin{array}{c}0.048 \\
(0.5191)\end{array}$ & $\begin{array}{c}-0.048 \\
(0.1790)\end{array}$ & $\begin{array}{c}0.033 \\
(0.4061)\end{array}$ & $\begin{array}{c}0.060^{*} \\
(0.0883)\end{array}$ & $\begin{array}{c}-0.019 \\
(0.7338)\end{array}$ & $\begin{array}{c}0.006 \\
(0.8962)\end{array}$ & $\begin{array}{c}-0.198^{* * *} \\
(0.0072)\end{array}$ & $\begin{array}{l}-0.008 \\
(0.8159)\end{array}$ \\
\hline$a_{i}$ & $\begin{array}{c}1.805^{* * *} \\
(0.0054)\end{array}$ & $\begin{array}{c}2.273^{* * *} \\
(0.0014)\end{array}$ & $\begin{array}{c}1.181^{* *} \\
(0.0108)\end{array}$ & $\begin{array}{l}1.173^{* *} \\
(0.0107)\end{array}$ & $\begin{array}{c}9.004^{* * *} \\
(0.0000)\end{array}$ & $\begin{array}{l}4.312^{* * *} \\
(0.0000)\end{array}$ & $\begin{array}{c}1.198^{* * *} \\
(0.0000)\end{array}$ & $\begin{array}{c}1.824^{* * *} \\
(0.0000)\end{array}$ \\
\hline$b_{i}$ & $\begin{array}{c}-0.006^{* * *} \\
(0.0026)\end{array}$ & $\begin{array}{c}-0.004^{* * * *} \\
(0.0000)\end{array}$ & $\begin{array}{c}-4.08 \mathrm{E}-04 \\
(0.4336)\end{array}$ & $\begin{array}{c}-0.005^{* * * *} \\
(0.0062)\end{array}$ & $\begin{array}{c}-0.010^{* * * *} \\
(0.0000)\end{array}$ & $\begin{array}{c}-0.003^{* * * *} \\
(0.0000)\end{array}$ & $\begin{array}{l}0.001^{* *} \\
(0.0176)\end{array}$ & $\begin{array}{l}0.001^{* *} \\
(0.0101)\end{array}$ \\
\hline Log-likelihood & \multirow{2}{*}{\multicolumn{2}{|c|}{$\begin{array}{c}9,088 \\
0.0000\end{array}$}} & \multirow{2}{*}{\multicolumn{2}{|c|}{$\begin{array}{l}10,130 \\
0.0000\end{array}$}} & \multirow{2}{*}{\multicolumn{2}{|c|}{$\begin{array}{l}13,708 \\
0.0000\end{array}$}} & \multirow{2}{*}{\multicolumn{2}{|c|}{$\begin{array}{c}9,523 \\
0.0000\end{array}$}} \\
\hline Hansen's p-value & & & & & & & & \\
\hline
\end{tabular}

Note: This table reports the estimation result of the two-state regime switching model. Estimation is done for five sample pairs consisting of one Shanghai Stock Exchange A- or B-share index and one commodity asset and results are separately shown. Coef. denotes model coefficients. SSEA index is the Shangha Stock Exchange A-share index; SSEB index is the Shanghai Stock Exchange B-share index. Hansen (1992)'s standardized likelihood ratio test is employed to test the existence of regimes and associated p-value of test statistic is shown. E stands for scientific notation. Figures in parentheses are $\mathrm{p}$ values of significance check. $* * * * *$ and $*$ represent significance at the $1 \%, 5 \%$ and $10 \%$, respectively. 
Table 4: Means and standard deviations of logarithmic ratios of time varying information share measures at 30-min intervals, Ratios of information share measures between SSEA index and other assets

\begin{tabular}{|c|c|c|c|c|c|}
\hline & & Oil & Bitcoin & US dollar & Corn \\
\hline \multicolumn{6}{|c|}{ P1: July 1, 2019 - November 16, 2019} \\
\hline \multirow[t]{2}{*}{ CS ratio } & Mean & 0.757 & 1.866 & -0.603 & -1.341 \\
\hline & STD & 1.513 & 1.856 & 1.53 & 1.129 \\
\hline \multirow{2}{*}{ IS ratio } & Mean & -0.8 & -0.014 & 0.77 & -1.237 \\
\hline & STD & 2.299 & 3.161 & 2.976 & 1.243 \\
\hline \multirow[t]{2}{*}{ ILS ratio } & Mean & -3.115 & -3.759 & 2.746 & 0.208 \\
\hline & STD & 1.687 & 2.686 & 2.91 & 1.077 \\
\hline \multicolumn{6}{|c|}{ P2: November 17, 2019 - December 30, 2019} \\
\hline \multirow{2}{*}{ CS ratio } & Mean & -0.665 & 1.314 & -2.027 & -1.21 \\
\hline & STD & 1.463 & 2.108 & 0.774 & 1.259 \\
\hline \multirow[t]{2}{*}{ IS ratio } & Mean & -2.394 & -0.642 & -2.079 & -1.307 \\
\hline & STD & 1.946 & 3.334 & 1.36 & 1.965 \\
\hline \multirow[t]{2}{*}{ ILS ratio } & Mean & -3.457 & -3.913 & -0.104 & -0.193 \\
\hline & STD & 1.37 & 2.639 & 1.206 & 1.49 \\
\hline \multicolumn{6}{|c|}{ P3: December 31, 2019 - April 10, 2020 } \\
\hline \multirow[t]{2}{*}{ CS ratio } & Mean & 0.502 & 1.185 & -0.93 & -1.172 \\
\hline & STD & 1.202 & 1.399 & 1.421 & 1.401 \\
\hline \multirow[t]{2}{*}{ IS ratio } & Mean & -0.384 & -0.909 & 0.441 & -0.719 \\
\hline & STD & 1.912 & 2.584 & 2.746 & 1.729 \\
\hline \multirow[t]{2}{*}{ ILS ratio } & Mean & -1.771 & -4.188 & 2.742 & 0.906 \\
\hline & STD & 1.455 & 2.391 & 2.659 & 1.145 \\
\hline \multicolumn{6}{|c|}{ Changes in means between sub-periods } \\
\hline \multicolumn{6}{|c|}{ Means in P2 minus Means in P1 } \\
\hline \multirow[t]{2}{*}{ CS ratio } & Diff. & -1.422 & -0.552 & -1.424 & 0.131 \\
\hline & F-stat & $249.490 * * *$ & $233.677^{* * *}$ & $85.783^{* * *}$ & $75.108^{* * *}$ \\
\hline \multirow[t]{2}{*}{ IS ratio } & Diff. & -1.594 & -0.628 & -2.849 & -0.07 \\
\hline & F-stat & $116.012^{* * *}$ & $182.623^{* * *}$ & $158.729^{* * *}$ & $77.813^{* * *}$ \\
\hline \multirow[t]{2}{*}{ ILS ratio } & Diff. & -0.342 & -0.154 & -2.85 & -0.401 \\
\hline & F-stat & $130.538^{* * *}$ & $158.415^{* * *}$ & $253.257^{* * *}$ & $186.772^{* * *}$ \\
\hline \multicolumn{6}{|c|}{ Means in P3 minus Means in P2 } \\
\hline \multirow[t]{2}{*}{ CS ratio } & Diff. & 1.167 & -0.129 & 1.097 & 0.038 \\
\hline & F-stat & $138.980^{* * *}$ & $135.776^{* * *}$ & $97.318^{* * *}$ & $61.929 * * *$ \\
\hline \multirow[t]{2}{*}{ IS ratio } & Diff. & 2.01 & -0.267 & 2.52 & 0.588 \\
\hline & F-stat & $55.427^{* * *}$ & $121.187^{* * *}$ & $120.971^{* * *}$ & $114.207^{* * *}$ \\
\hline \multirow[t]{2}{*}{ ILS ratio } & Diff. & 1.686 & -0.275 & 2.846 & 1.099 \\
\hline & F-stat & $34.931 * * *$ & $124.751^{* * *}$ & $159.924^{* * *}$ & $177.958^{* * *}$ \\
\hline
\end{tabular}

Note: Logarithmic ratios of information share measures are calculated as the natural logarithms of ratios of time varying information share measures of Shanghai Stock Exchange A and B-share indices over the other five assets. CS, component share; IS, information share; ILS, information leadership share. Time varying information share measures are computed based on time varying error correction coefficients from a rolling window procedure as well as the variance-covariance matrix of innovations derived from a two-state regime switching model. SSEA index is the Shanghai Stock Exchange A-share index; SSEB index is the Shanghai Stock Exchange B-share index. STD is standard deviation. Diff. represents the result of subtraction in means. F-stat denotes the $\mathrm{F}$ test statistic for the hypothesis testing on equality between means of different Sub-periods. ${ }^{* * *}$ denotes significance at the $1 \%$ level 
Table 5: Means and standard deviations of logarithmic ratios of time varying information share measures at 30-min intervals, Ratios of information share measures between SSEB index and other assets

\begin{tabular}{|c|c|c|c|c|c|}
\hline & & Oil & Bitcoin & US dollar & Corn \\
\hline \multicolumn{6}{|c|}{ P1: July 1, 2019 - November 16, 2019} \\
\hline \multirow[t]{2}{*}{ CS ratio } & Mean & 0.38 & 1.854 & -0.71 & -0.509 \\
\hline & STD & 1.908 & 1.588 & 1.526 & 1.717 \\
\hline \multirow{2}{*}{ IS ratio } & Mean & -1.739 & -0.179 & 0.518 & -0.177 \\
\hline & STD & 3.221 & 2.697 & 3.045 & 2.204 \\
\hline \multirow[t]{2}{*}{ ILS ratio } & Mean & -4.238 & -4.067 & 2.456 & 0.664 \\
\hline & STD & 2.744 & 2.276 & 3.064 & 1.438 \\
\hline \multicolumn{6}{|c|}{ P2: November 17, 2019 - December 30, 2019} \\
\hline \multirow{2}{*}{ CS ratio } & Mean & -0.885 & 0.32 & -0.777 & -1.138 \\
\hline & STD & 1.458 & 1.918 & 1.522 & 1.415 \\
\hline \multirow[t]{2}{*}{ IS ratio } & Mean & -2.376 & -1.88 & 1.049 & -0.582 \\
\hline & STD & 2.324 & 3.007 & 2.741 & 2.006 \\
\hline \multirow[t]{2}{*}{ ILS ratio } & Mean & -2.981 & -4.399 & 3.652 & 1.111 \\
\hline & STD & 1.864 & 2.324 & 2.479 & 1.454 \\
\hline \multicolumn{6}{|c|}{ P3: December 31, 2019 - April 10, 2020 } \\
\hline \multirow[t]{2}{*}{ CS ratio } & Mean & -0.275 & 0.989 & -1.8 & -0.845 \\
\hline & STD & 1.367 & 1.356 & 1.669 & 1.371 \\
\hline \multirow[t]{2}{*}{ IS ratio } & Mean & -1.917 & -1.153 & -1.072 & -0.127 \\
\hline & STD & 2.43 & 2.436 & 2.908 & 1.816 \\
\hline \multirow[t]{2}{*}{ ILS ratio } & Mean & -3.284 & -4.284 & 1.457 & 1.436 \\
\hline & STD & 2.18 & 2.22 & 2.569 & 1.105 \\
\hline \multicolumn{6}{|c|}{ Changes in means between sub-periods } \\
\hline \multicolumn{6}{|c|}{ Means in P2 minus Means in P1 } \\
\hline \multirow[t]{2}{*}{ CS ratio } & Diff. & -1.265 & -1.534 & -0.067 & -0.629 \\
\hline & F-stat & $150.441^{* * *}$ & $211.594 * * *$ & $35.509 * * *$ & $50.557^{* * *}$ \\
\hline \multirow[t]{2}{*}{ IS ratio } & Diff. & -0.637 & -1.701 & 0.531 & -0.405 \\
\hline & F-stat & $95.603^{* * *}$ & $127.562^{* * *}$ & $120.847^{* * *}$ & $130.368^{* * *}$ \\
\hline \multirow[t]{2}{*}{ ILS ratio } & Diff. & 1.257 & -0.332 & 1.196 & 0.447 \\
\hline & F-stat & $271.111^{* * *}$ & $126.741^{* * *}$ & $188.183^{* * *}$ & $179.073^{* * *}$ \\
\hline \multicolumn{6}{|c|}{ Means in P3 minus Means in P2 } \\
\hline \multirow[t]{2}{*}{ CS ratio } & Diff. & 0.61 & 0.669 & -1.023 & 0.293 \\
\hline & F-stat & $96.832^{* * *}$ & $184.042^{* * *}$ & $92.172^{* * *}$ & $56.733^{* * *}$ \\
\hline \multirow[t]{2}{*}{ IS ratio } & Diff. & 0.459 & 0.727 & -2.121 & 0.455 \\
\hline & F-stat & $48.089 * * *$ & $137.220^{* * *}$ & $195.538^{* * *}$ & $79.335^{* * *}$ \\
\hline \multirow[t]{2}{*}{ ILS ratio } & Diff. & -0.303 & 0.115 & -2.195 & 0.325 \\
\hline & F-stat & $91.666^{* * *}$ & $87.623^{* * *}$ & $123.523^{* * *}$ & $105.200^{* * *}$ \\
\hline
\end{tabular}

Note: Logarithmic ratios of information share measures are calculated as the natural logarithms of ratios of time varying information share measures of Shanghai Stock Exchange A and B-share indices over the other five assets. CS, component share; IS, information share; ILS, information leadership share. Time varying information share measures are computed based on time varying error correction coefficients from a rolling window procedure as well as the variance-covariance matrix of innovations derived from a two-state regime switching model. SSEA index is the Shanghai Stock Exchange A-share index; SSEB index is the Shanghai Stock Exchange B-share index. STD is standard deviation. Diff. represents the result of subtraction in means. F-stat denotes the $\mathrm{F}$ test statistic for the hypothesis testing on equality between means of different Sub-periods. ${ }^{* * *}$ denotes significance at the $1 \%$ level 
Table 6: Means and standard deviations of time varying net spillovers of higher moments at 30-min intervals, Net spillovers from SSEA index to other assets

\begin{tabular}{|c|c|c|c|c|c|}
\hline & & Oil & Bitcoin & US dollar & Corn \\
\hline \multicolumn{6}{|c|}{ P1: July 1, 2019 - November 16, 2019} \\
\hline \multirow[t]{2}{*}{ Volatility spillover } & Mean & $2.634^{* * *}$ & $0.171^{* * *}$ & $-4.044 * * *$ & $0.456^{* * *}$ \\
\hline & STD & 3.254 & 0.129 & 0.34 & 0.246 \\
\hline \multirow[t]{2}{*}{ Skewness spillover } & Mean & $0.187^{* * *}$ & $-0.077^{* * *}$ & $-1.101^{* * *}$ & $0.554^{* * *}$ \\
\hline & STD & 0.112 & 0.14 & 1.105 & 0.406 \\
\hline \multirow[t]{2}{*}{ Kurtosis spillover } & Mean & $0.486^{* * *}$ & $-0.095^{* * *}$ & $-0.079 * * *$ & $1.639 * * *$ \\
\hline & STD & 0.546 & 0.167 & 0.111 & 0.31 \\
\hline \multicolumn{6}{|c|}{ P2: November 17, 2019 - December 30, 2019} \\
\hline \multirow[t]{2}{*}{ Volatility spillover } & Mean & $9.603^{* * *}$ & $1.261 * * *$ & $-2.458 * * *$ & $0.394 * * *$ \\
\hline & STD & 9.054 & 2.779 & 1.761 & 0.139 \\
\hline \multirow[t]{2}{*}{ Skewness spillover } & Mean & $0.112^{* * *}$ & $0.128^{* * *}$ & $-1.400^{* * *}$ & $0.383^{* * *}$ \\
\hline & STD & 0.099 & 0.084 & 0.681 & 0.277 \\
\hline \multirow{2}{*}{ Kurtosis spillover } & Mean & $0.989 * * *$ & $-0.272^{* * *}$ & $-0.162^{* * *}$ & $0.647 * * *$ \\
\hline & STD & 0.43 & 0.261 & 0.064 & 0.36 \\
\hline \multicolumn{6}{|c|}{ P3: December 31, 2019 - April 10, 2020 } \\
\hline \multirow[t]{2}{*}{ Volatility spillover } & Mean & $7.544^{* * *}$ & $2.188^{* * *}$ & $-11.114^{* * *}$ & $0.249 * * *$ \\
\hline & STD & 6.635 & 4.788 & 24.37 & 0.316 \\
\hline \multirow[t]{2}{*}{ Skewness spillover } & Mean & $0.079 * * *$ & $1.242^{* * *}$ & $-1.170 * * *$ & $0.389 * * *$ \\
\hline & STD & 0.174 & 1.119 & 1.409 & 0.407 \\
\hline \multirow[t]{2}{*}{ Kurtosis spillover } & Mean & $1.611^{* * *}$ & $0.111^{* * *}$ & $-0.260 * * *$ & $2.352^{* * *}$ \\
\hline & STD & 1.092 & 0.227 & 0.516 & 0.76 \\
\hline \multicolumn{6}{|c|}{ Changes in means between sub-periods } \\
\hline \multicolumn{6}{|c|}{ Means in P2 minus Means in P1 } \\
\hline \multirow[t]{2}{*}{ Volatility spillover } & Diff. & 6.969 & 1.09 & 1.586 & -0.062 \\
\hline & F-stat & $145.696^{* * *}$ & $20.110^{* * *}$ & $9.576^{* * *}$ & $105.069^{* * *}$ \\
\hline \multirow[t]{2}{*}{ Skewness spillover } & Diff. & -0.075 & 0.205 & -0.299 & -0.171 \\
\hline & F-stat & $92.375^{* * *}$ & $49.970 * * *$ & $114.475^{* * *}$ & $134.948^{* * *}$ \\
\hline \multirow[t]{2}{*}{ Kurtosis spillover } & Diff. & 0.503 & -0.177 & -0.083 & -0.992 \\
\hline & F-stat & $11.523^{* * *}$ & $245.699 * * *$ & $14.390^{* * *}$ & $45.397^{* * *}$ \\
\hline \multicolumn{6}{|c|}{ Means in P3 minus Means in P2 } \\
\hline \multirow[t]{2}{*}{ Volatility spillover } & Diff. & -2.059 & 0.927 & -8.656 & -0.145 \\
\hline & F-stat & $1093.820^{* * *}$ & $6845.744^{* * *}$ & $929.221^{* * *}$ & $144.655^{* * *}$ \\
\hline \multirow[t]{2}{*}{ Skewness spillover } & Diff. & -0.033 & 1.114 & 0.23 & 0.006 \\
\hline & F-stat & $221.015^{* * *}$ & $1919.652^{* * *}$ & $202.956^{* * *}$ & $63.258^{* * *}$ \\
\hline \multirow[t]{2}{*}{ Kurtosis spillover } & Diff. & 0.622 & 0.383 & -0.098 & 1.705 \\
\hline & F-stat & $486.993^{* * *}$ & $152.547^{* * *}$ & $695.525^{* * *}$ & $347.795^{* * *}$ \\
\hline
\end{tabular}

Note: Net spillovers from the Shanghai Stock Exchange A- and B-share indices to other assets are calculated as the differences between absolute values of spillovers from A- and B-share indices to other assets and absolute values of spillovers of the other way around. And time varying spillovers are derived via a rolling window procedure on an extended VAR(1) model. Time varying higher moments are obtained via a two-state regime switching model. The null hypothesis that means of net spillovers are zero is tested. SSEA index is the Shanghai Stock Exchange A-share index; SSEB index is the Shanghai Stock Exchange B-share index. STD is standard deviation. Diff. represents the result of subtraction in means. F-stat denotes the F test statistic for the hypothesis testing on equality between means of different Sub-periods. E stands for scientific notation. ${ }^{* * *}$ denotes significance at the $1 \%$ level. 
Table 7: Means and standard deviations of time varying net spillovers of higher moments at 30-min intervals, Net spillovers from SSEB index to other assets

\begin{tabular}{|c|c|c|c|c|c|}
\hline & & Oil & Bitcoin & US dollar & Corn \\
\hline \multicolumn{6}{|c|}{ P1: July 1, 2019 - November 16, 2019} \\
\hline \multirow[t]{2}{*}{ Volatility spillover } & Mean & 0.004 & $-4.916^{* * *}$ & $-4.916^{* * *}$ & $0.281^{* * *}$ \\
\hline & STD & 0.056 & 0.668 & 0.668 & 0.164 \\
\hline \multirow[t]{2}{*}{ Skewness spillover } & Mean & $-3.953^{* * *}$ & $-0.240^{* * *}$ & $-0.240 * * *$ & $0.469^{* * *}$ \\
\hline & STD & 2.221 & 0.366 & 0.366 & 0.339 \\
\hline \multirow[t]{2}{*}{ Kurtosis spillover } & Mean & $-0.094^{* * *}$ & 0.003 & 0.003 & $0.879 * * *$ \\
\hline & STD & 0.047 & 0.338 & 0.338 & 0.29 \\
\hline \multicolumn{6}{|c|}{ P2: November 17, 2019 - December 30, 2019} \\
\hline \multirow[t]{2}{*}{ Volatility spillover } & Mean & $1.660^{* * *}$ & $-7.494 * * *$ & $-7.494^{* * *}$ & $0.328^{* * *}$ \\
\hline & STD & 2.354 & 6.482 & 6.482 & 0.289 \\
\hline \multirow[t]{2}{*}{ Skewness spillover } & Mean & $-1.135^{* * *}$ & $-0.151^{* * *}$ & $-0.151^{* * *}$ & $0.722^{* * *}$ \\
\hline & STD & 1.08 & 0.233 & 0.233 & 0.319 \\
\hline \multirow[t]{2}{*}{ Kurtosis spillover } & Mean & $-0.355^{* * *}$ & $0.082^{* * *}$ & $0.082^{* * *}$ & $0.540^{* * *}$ \\
\hline & STD & 0.327 & 0.049 & 0.049 & 0.268 \\
\hline \multicolumn{6}{|c|}{ P3: December 31, 2019 - April 10, 2020 } \\
\hline \multirow[t]{2}{*}{ Volatility spillover } & Mean & $0.463^{* * *}$ & $-20.107^{* * *}$ & $-20.107^{* * *}$ & $0.045^{* * *}$ \\
\hline & STD & 1.473 & 21.411 & 21.411 & 0.175 \\
\hline \multirow[t]{2}{*}{ Skewness spillover } & Mean & $-2.511^{* * *}$ & $-0.648^{* * *}$ & $-0.648^{* * *}$ & $0.638^{* * *}$ \\
\hline & STD & 1.639 & 0.846 & 0.846 & 0.743 \\
\hline \multirow[t]{2}{*}{ Kurtosis spillover } & Mean & $-0.259 * * *$ & $0.034^{* *}$ & $0.034^{* *}$ & $1.453^{* * *}$ \\
\hline & STD & 0.181 & 0.31 & 0.31 & 0.443 \\
\hline \multicolumn{6}{|c|}{ Changes in means between sub-periods } \\
\hline \multicolumn{6}{|c|}{ Means in P2 minus Means in P1 } \\
\hline \multirow[t]{2}{*}{ Volatility spillover } & Diff. & 1.656 & -2.578 & -2.578 & 0.047 \\
\hline & F-stat & $255.054^{* * *}$ & $60.473^{* * *}$ & $60.473^{* * *}$ & $386.927^{* * *}$ \\
\hline \multirow[t]{2}{*}{ Skewness spillover } & Diff. & 2.818 & 0.089 & 0.089 & 0.253 \\
\hline & F-stat & $213.167^{* * *}$ & $27.299 * * *$ & $27.299 * * *$ & $36.155^{* * *}$ \\
\hline \multirow[t]{2}{*}{ Kurtosis spillover } & Diff. & -0.261 & 0.079 & 0.079 & -0.339 \\
\hline & F-stat & $247.604^{* * *}$ & $183.382^{* * *}$ & $183.382^{* * *}$ & $73.834^{* * *}$ \\
\hline \multicolumn{6}{|c|}{ Means in P3 minus Means in P2 } \\
\hline \multirow[t]{2}{*}{ Volatility spillover } & Diff. & -1.197 & -12.613 & -12.613 & -0.283 \\
\hline & F-stat & $4405.156^{* * *}$ & $4220.064^{* * *}$ & $4220.064^{* * *}$ & $271.678^{* * *}$ \\
\hline \multirow[t]{2}{*}{ Skewness spillover } & Diff. & -1.376 & -0.497 & -0.497 & -0.084 \\
\hline & F-stat & $95.037 * * *$ & $564.252^{* * *}$ & $564.252^{* * *}$ & $337.776^{* * *}$ \\
\hline \multirow[t]{2}{*}{ Kurtosis spillover } & Diff. & 0.096 & -0.048 & -0.048 & 0.913 \\
\hline & F-stat & $657.245^{* * *}$ & $104.740^{* * *}$ & $104.740^{* * *}$ & $374.478^{* * *}$ \\
\hline
\end{tabular}

Note: Net spillovers from the Shanghai Stock Exchange A- and B-share indices to other assets are calculated as the differences between absolute values of spillovers from A- and B-share indices to other assets and absolute values of spillovers of the other way around. And time varying spillovers are derived via a rolling window procedure on an extended VAR(1) model. Time varying higher moments are obtained via a two-state regime switching model. The null hypothesis that means of net spillovers are zero is tested. SSEA index is the Shanghai Stock Exchange A-share index; SSEB index is the Shanghai Stock Exchange B-share index. STD is standard deviation. Diff. represents the result of subtraction in means. F-stat denotes the F test statistic for the hypothesis testing on equality between means of different Sub-periods. E stands for scientific notation. ${ }^{* * *}$ denotes significance at the $1 \%$ level. 
Table 8: News events with largest denoted frequency per date of largest SSEA volatility spillover

\begin{tabular}{|c|c|c|c|c|c|c|c|c|c|}
\hline SSEA \& Oil & \% & $\begin{array}{l}\text { COVID-19 } \\
\text { Period }\end{array}$ & $\begin{array}{l}\text { COVID-19 } \\
\text { Influence }\end{array}$ & $\begin{array}{l}\text { FT Main } \\
\text { Headline }\end{array}$ & SSEA \& Bitcoin & $\%$ & $\begin{array}{l}\text { COVID-19 } \\
\text { Period }\end{array}$ & $\begin{array}{l}\begin{array}{l}\text { COVID-19 } \\
\text { Influence }\end{array} \\
\end{array}$ & $\begin{array}{l}\text { FT Main } \\
\text { Headline }\end{array}$ \\
\hline 26/Aug/2019 & 38.72 & No & No & $\begin{array}{l}\text { Political - EU looks to rewrite } \\
\text { budget rules as bloc's economic } \\
\text { growth falters }\end{array}$ & $24 / \mathrm{Feb} / 2020$ & 304.27 & World & Yes & $\begin{array}{l}\text { Coronavirus - Italy locks down } 10 \\
\text { towns as fears rise for global coro } \\
\text { navirus spread }\end{array}$ \\
\hline $18 /$ Oct $/ 2019$ & 26.90 & No & No & $\begin{array}{l}\text { growh falters } \\
\text { Political - Johnson's Brexit gam- } \\
\text { ble faces threat of Westminister } \\
\text { veto }\end{array}$ & $27 / \mathrm{Feb} / 2020$ & 77.39 & World & Yes & $\begin{array}{l}\text { navirus spread } \\
\text { Coronavirus - Infection spread } \\
\text { speeds up beyond China as virus } \\
\text { breaks new ground }\end{array}$ \\
\hline $23 / \mathrm{Jan} / 2020$ & 18.86 & World & Yes & $\begin{array}{l}\text { Economic - Trump expects trade } \\
\text { deal with EU before presidential } \\
\text { election }\end{array}$ & $03 / \mathrm{Feb} / 2020$ & 39.65 & World & Yes & $\begin{array}{l}\text { Coronavirus - Beijing deploys } \\
\text { emergency cash to shield markets } \\
\text { from virus fallout }\end{array}$ \\
\hline $24 / \mathrm{Feb} / 2020$ & 12.90 & World & Yes & $\begin{array}{l}\text { Coronavirus - Italy locks down } 10 \\
\text { towns as fears rise for global coro- } \\
\text { navirus spread }\end{array}$ & 04/Dec/2019 & 38.90 & China & Yes & $\begin{array}{l}\text { Equities - Investors spooked by } \\
\text { Trump's willingness to delay trade } \\
\text { deal }\end{array}$ \\
\hline 19/Jul/2019 & 9.92 & No & No & $\begin{array}{l}\text { Political - Russia backs EU pay- } \\
\text { ment scheme to help Iranians } \\
\text { sidestep sanctions }\end{array}$ & 31/Dec/2019 & 38.01 & China & Yes & $\begin{array}{l}\text { Bonds - Bond market barometer } \\
\text { points to investor optimism as } \\
\text { year ends }\end{array}$ \\
\hline 16/Dec/2019 & 7.46 & China & Yes & $\begin{array}{l}\text { Political - UN talks on climate } \\
\text { change break up in stalemate }\end{array}$ & $27 / \mathrm{Feb} / 2020$ & 33.68 & World & Yes & $\begin{array}{l}\text { Coronavirus - Infection spread } \\
\text { speeds up beyond China as virus } \\
\text { breaks new ground }\end{array}$ \\
\hline $17 / \mathrm{Sep} / 2019$ & 7.44 & No & No & $\begin{array}{l}\text { Oil - Oil price spikes as fears } \\
\text { mount over Saudi supply disrup- } \\
\text { tion }\end{array}$ & $21 / \mathrm{Feb} / 2020$ & 29.60 & World & Yes & $\begin{array}{l}\text { Equities - Morgan Stanley joins } \\
\text { rush into retail with } \$ 13 \text { bn Etrade } \\
\text { swoop }\end{array}$ \\
\hline 21/Aug/2019 & 7.29 & No & No & $\begin{array}{l}\text { Political - Conte blames Salvini for } \\
\text { Italy's strife and quites as prime } \\
\text { minister }\end{array}$ & $03 / \mathrm{Feb} / 2020$ & 14.75 & World & Yes & $\begin{array}{l}\text { Coronavirus - Beijing deploys } \\
\text { emergency cash to shield market } \\
\text { from virus fallout }\end{array}$ \\
\hline
\end{tabular}

\begin{tabular}{|c|c|c|c|c|c|c|c|c|c|}
\hline SSEA \& USD\$ & $\%$ & $\begin{array}{l}\text { COVID-19 } \\
\text { Period }\end{array}$ & $\begin{array}{l}\text { COVID-19 } \\
\text { Influence }\end{array}$ & $\begin{array}{l}\text { FT Main } \\
\text { Headline }\end{array}$ & SSEA \& Corn & $\%$ & $\begin{array}{l}\text { COVID-19 } \\
\text { Period }\end{array}$ & $\begin{array}{l}\text { COVID-19 } \\
\text { Influence }\end{array}$ & $\begin{array}{l}\text { FT Main } \\
\text { Headline }\end{array}$ \\
\hline 03/Dec/2019 & 20.83 & China & Yes & $\begin{array}{l}\text { Polticial - Beijing strikes back at } \\
\text { Trump's support for Hong Kong } \\
\text { protests }\end{array}$ & 06/Dec/2019 & 179.62 & China & Yes & $\begin{array}{l}\text { Oil - Saudi Aramaco's } \$ 25.6 \mathrm{bn} \\
\text { breaks IPO record despite valua- } \\
\text { tion blow }\end{array}$ \\
\hline $27 / \mathrm{Mar} / 2020$ & 15.19 & World & Yes & $\begin{array}{l}\text { Economic - Jobless claims surge to } \\
3.3 \mathrm{~m} \text { record in US }\end{array}$ & 18/Nov/2019 & 49.00 & China & Yes & $\begin{array}{l}\text { Oil - Aramco pares back fundrais- } \\
\text { ing goal to } \$ 25 \mathrm{bn} \text { in latest IPO } \\
\text { hitch }\end{array}$ \\
\hline 26/Mar/2020 & 12.57 & World & Yes & $\begin{array}{l}\text { Coronavirus - Poorest nations } \\
\text { need debt relief to tackle virus, say } \\
\text { global lenders }\end{array}$ & 31/Dec/2019 & 12.01 & World & Yes & $\begin{array}{l}\text { Bonds - Bond market barometer } \\
\text { points to investor optimism as } \\
\text { year ends }\end{array}$ \\
\hline $21 /$ Nov/ 2019 & 10.31 & China & Yes & $\begin{array}{l}\text { Political - Sondland followed or- } \\
\text { ders from Trump on Ukraine quid } \\
\text { pro quo }\end{array}$ & $12 / \mathrm{Feb} / 2020$ & 7.42 & World & Yes & $\begin{array}{l}\text { Political - Antitrust chiefs press } \\
\text { Big Tech over buying spree for } \\
\text { start ups }\end{array}$ \\
\hline $25 /$ Nov $/ 2019$ & 4.02 & China & Yes & $\begin{array}{l}\text { Economic - LVMH poised to secure } \\
\text { Tiffany as Arnault raises offer to } \\
\$ 16.7 \mathrm{bn}\end{array}$ & $10 / \mathrm{Feb} / 2020$ & 5.73 & World & Yes & $\begin{array}{l}\text { Coronavirus - Shut businesses hit } \\
\text { China push to restart economy } \\
\text { amid killer virus }\end{array}$ \\
\hline 31/Dec/2019 & 3.78 & China & Yes & $\begin{array}{l}\text { Bonds - Bond market barometer } \\
\text { points to investor optimism as } \\
\text { year ends }\end{array}$ & $30 / \mathrm{Sep} / 2019$ & 3.58 & No & No & $\begin{array}{l}\text { Central Bank - Draghi backs calls } \\
\text { for fiscal union to bolster eurozone } \\
\text { against rivals }\end{array}$ \\
\hline $01 / \mathrm{Apr} / 2020$ & 2.99 & World & Yes & $\begin{array}{l}\text { Economic - Chinese factories find } \\
\text { new life but European outlook } \\
\text { darkens }\end{array}$ & $13 / \mathrm{Feb} / 2020$ & 2.49 & World & Yes & $\begin{array}{l}\text { Currency - Patents lay bare scale } \\
\text { of China's ambition to digitise the } \\
\text { renmimbi }\end{array}$ \\
\hline $21 / \mathrm{Jan} / 2020$ & 2.54 & World & Yes & $\begin{array}{l}\text { Economic - Downbeat IMF out- } \\
\text { look diverts Davos focus from cli- } \\
\text { mate goals }\end{array}$ & 02/Aug/2019 & 1.94 & No & No & $\begin{array}{l}\text { Political - EU impasses forces vote } \\
\text { on picking candidate to follow La- } \\
\text { garde at IMF }\end{array}$ \\
\hline
\end{tabular}

Note: The above table represents the news events that occurred on the date of the largest SSEA volatility spillover. Data is obtained through The Financial Times and LexisNexis. 
Table 9: News events with largest denoted frequency per date of largest SSEB volatility spillover

\begin{tabular}{|c|c|c|c|c|c|c|c|c|c|}
\hline SSEB \& Oil & $\%$ & $\begin{array}{l}\text { COVID-19 } \\
\text { Period }\end{array}$ & $\begin{array}{l}\text { COVID-19 } \\
\text { Influence }\end{array}$ & $\begin{array}{l}\text { FT Main } \\
\text { Headline }\end{array}$ & SSEB \& Bitcoin & $\%$ & $\begin{array}{l}\text { COVID-19 } \\
\text { Period }\end{array}$ & $\begin{array}{l}\text { COVID-19 } \\
\text { Influence }\end{array}$ & $\begin{array}{l}\text { FT Main } \\
\text { Headline }\end{array}$ \\
\hline 31/Dec/2019 & 50.84 & China & Yes & $\begin{array}{l}\text { Bonds - Bond market barometer } \\
\text { points to investor optimism as } \\
\text { year ends }\end{array}$ & $18 /$ Nov/2019 & 574.92 & China & Yes & $\begin{array}{l}\text { Oil - Aramco pares back fundrais- } \\
\text { ing goal to } \$ 25 \mathrm{bn} \text { in latest IPO } \\
\text { hitch }\end{array}$ \\
\hline $17 / \mathrm{Sep} / 2019$ & 19.56 & No & No & $\begin{array}{l}\text { Oil - Oil price spikes as fears } \\
\text { mount over Saudi supply disrup- } \\
\text { tion }\end{array}$ & 31/Dec/2019 & 32.83 & World & Yes & $\begin{array}{l}\text { Bonds - Bond market barometer } \\
\text { points to investor optimism as } \\
\text { year ends }\end{array}$ \\
\hline $16 / \mathrm{Sep} / 2019$ & 13.61 & No & No & $\begin{array}{l}\text { Oil - Saudis seek to reassure mar- } \\
\text { kets as attack halves oil produc- } \\
\text { tion }\end{array}$ & 19/Dec/2019 & 5.05 & China & Yes & $\begin{array}{l}\text { Economic - Fiat Chrysler agrees } \\
\text { merger with Peugeot to forget } \\
\text { 40bn carmaker }\end{array}$ \\
\hline 18/Nov/2019 & 13.46 & China & Yes & $\begin{array}{l}\text { Oil - Aramco pares back fundrais- } \\
\text { ing goal to } \$ 25 \mathrm{bn} \text { in latest IPO } \\
\text { hitch }\end{array}$ & 06/Dec/2019 & 4.37 & China & Yes & $\begin{array}{l}\text { Oil - Saudi Aramaco's } \$ 25.6 \mathrm{bn} \\
\text { breaks IPO record despite valua- } \\
\text { tion blow }\end{array}$ \\
\hline $17 / \mathrm{Jan} / 2020$ & 3.03 & China & Yes & $\begin{array}{l}\text { Oil- Berlin secures } 40 \mathrm{bn} \text { deal with } \\
\text { regions to end use of coal by } 2038\end{array}$ & 05/Dec/2019 & 2.58 & China & Yes & $\begin{array}{l}\text { Political - Germany sees Kremlin's } \\
\text { hand in Berlin murder of Chechen } \\
\text { rebel }\end{array}$ \\
\hline 15/Aug/2019 & 2.99 & No & No & $\begin{array}{l}\text { Economic - Bonds sound recession } \\
\text { alarm as China and Germany show } \\
\text { strain }\end{array}$ & $09 / \mathrm{Mar} / 2020$ & 2.46 & World & Yes & $\begin{array}{l}\text { Coronavirus - Italy quarantines } \\
\text { vast parts of rich north as virus } \\
\text { cases surge }\end{array}$ \\
\hline 16/Sep/2019 & 2.50 & No & No & $\begin{array}{l}\text { Oil - Saudis seek to reassure mar- } \\
\text { kets as attack halves oil produc- } \\
\text { tion }\end{array}$ & 13/Mar/2020 & 1.93 & World & Yes & $\begin{array}{l}\text { Equities - Tramautic day on global } \\
\text { markets spurs central banks to } \\
\text { step up action }\end{array}$ \\
\hline $09 / \mathrm{Jan} / 2020$ & 2.49 & World & Yes & $\begin{array}{l}\text { Political - US and Ukraine fear } \\
\text { Iran missile downed passenger jet } \\
\text { in error }\end{array}$ & 05/Dec/2019 & 1.28 & China & Yes & $\begin{array}{l}\text { Political - Germany sees Kremlin's } \\
\text { hand in Berlin murder of Chechen } \\
\text { rebel }\end{array}$ \\
\hline SSEB \& USD\$ & $\%$ & $\begin{array}{l}\text { COVID-19 } \\
\text { Period } \\
\end{array}$ & $\begin{array}{l}\text { COVID-19 } \\
\text { Influence }\end{array}$ & $\begin{array}{l}\text { FT Main } \\
\text { Headline }\end{array}$ & SSEB \& Corn & $\%$ & $\begin{array}{l}\text { COVID-19 } \\
\text { Period }\end{array}$ & $\begin{array}{l}\text { COVID-19 } \\
\text { Influence }\end{array}$ & $\begin{array}{l}\text { FT Main } \\
\text { Headline }\end{array}$ \\
\hline 18/Nov/2019 & 13.04 & China & Yes & $\begin{array}{l}\text { Oil - Aramco pares back fundrais- } \\
\text { ing goal to } \$ 25 \mathrm{bn} \text { in latest IPO } \\
\text { hitch }\end{array}$ & 23/Dec/2019 & 9.98 & China & Yes & $\begin{array}{l}\text { Political - Boeing chief Mullenburg } \\
\text { ousted for failing to stem } 737 \text { Max } \\
\text { crisis }\end{array}$ \\
\hline $17 / \mathrm{Jan} / 2020$ & 5.80 & World & Yes & $\begin{array}{l}\text { Oil - Berlin secures } 40 \mathrm{bn} \text { deal with } \\
\text { regions to end use of coal by } 2038\end{array}$ & $13 / \mathrm{Feb} / 2020$ & 8.22 & World & Yes & $\begin{array}{l}\text { Currency - Patents lay bare scale } \\
\text { of China's ambition to digitise the } \\
\text { renmimbi }\end{array}$ \\
\hline $21 / \mathrm{Jan} / 2020$ & 1.19 & World & Yes & $\begin{array}{l}\text { Economic - Downbeat IMF out- } \\
\text { look diverts Davos focus from cli- } \\
\text { mate goals }\end{array}$ & $08 / \mathrm{Apr} / 2020$ & 3.98 & World & Yes & $\begin{array}{l}\text { Coronavirus - Pandemic will de- } \\
\text { stroy equivalent of } 195 \mathrm{~m} \text { jobs } \\
\text { worldwide, warns UN }\end{array}$ \\
\hline 06/Dec/2019 & 0.96 & China & Yes & $\begin{array}{l}\text { Oil - Saudi Aramaco's } \$ 25.6 \mathrm{bn} \\
\text { breaks IPO record despite valua- } \\
\text { tion blow }\end{array}$ & $03 / \mathrm{Apr} / 2020$ & 3.10 & World & Yes & $\begin{array}{l}\text { Economic - Jobless claims surge in } \\
\text { Europe and US as global economy } \\
\text { stifles }\end{array}$ \\
\hline 31/Dec/2019 & 0.92 & China & Yes & $\begin{array}{l}\text { Bonds - Bond market barometer } \\
\text { points to investor optimism as } \\
\text { year ends }\end{array}$ & 23/Dec/2019 & 2.16 & China & Yes & $\begin{array}{l}\text { Political - Boeing chief Mullenburg } \\
\text { ousted for failing to stem } 737 \mathrm{Max} \\
\text { crisis }\end{array}$ \\
\hline $21 / \mathrm{Jan} / 2020$ & 0.89 & World & Yes & $\begin{array}{l}\text { Economic - Downbeat IMF out- } \\
\text { look diverts Davos focus from cli- } \\
\text { mate goals }\end{array}$ & $07 / \mathrm{Apr} / 2020$ & 2.14 & World & Yes & $\begin{array}{l}\text { Coronavirus - UK doctors reveal } \\
\text { multi-organ danger posed by coro- } \\
\text { navirus }\end{array}$ \\
\hline $17 / \mathrm{Jan} / 2020$ & 0.62 & World & Yes & $\begin{array}{l}\text { Oil - Berlin secures } 40 \mathrm{bn} \text { deal with } \\
\text { regions to end use of coal by } 2038\end{array}$ & $03 / \mathrm{Feb} / 2020$ & 2.05 & World & Yes & $\begin{array}{l}\text { Coronavirus - Beijing deploys } \\
\text { emergency cash to shield markets } \\
\text { from virus fallout }\end{array}$ \\
\hline 12/Dec/2019 & 0.47 & China & Yes & $\begin{array}{l}\text { Political - US tightens screws on } \\
\text { Iran with fresh shipping and air } \\
\text { sanctions }\end{array}$ & 19/Dec/2019 & 1.94 & China & Yes & $\begin{array}{l}\text { Economic - Fiat Chrysler agrees } \\
\text { merger with Peugeot to forget } \\
\text { 40bn carmaker }\end{array}$ \\
\hline
\end{tabular}

Note: The above table represents the news events that occurred on the date of the largest SSEB volatility spillover. Data is obtained through The Financial Times and LexisNexis. 
Table 10: News events with largest denoted frequency per date of largest SSEA skewness spillover

\begin{tabular}{|c|c|c|c|c|c|c|c|c|c|}
\hline SSEA \& Oil & $\%$ & $\begin{array}{l}\text { COVID-19 } \\
\text { Period }\end{array}$ & $\begin{array}{l}\text { COVID-19 } \\
\text { Influence }\end{array}$ & $\begin{array}{l}\text { FT Main } \\
\text { Headline }\end{array}$ & SSEA \& Bitcoin & $\%$ & $\begin{array}{l}\text { COVID-19 } \\
\text { Period }\end{array}$ & $\begin{array}{l}\text { COVID-19 } \\
\text { Influence }\end{array}$ & $\begin{array}{l}\text { FT Main } \\
\text { Headline }\end{array}$ \\
\hline 18/Nov/2019 & 282.74 & China & Yes & $\begin{array}{l}\text { Oil - Aramco pares back fundrais- } \\
\text { ing goal to } \$ 25 \mathrm{bn} \text { in latest IPO } \\
\text { hitch }\end{array}$ & $24 / \mathrm{Feb} / 2020$ & 15.49 & World & Yes & $\begin{array}{l}\text { Coronavirus - Italy locks down } 10 \\
\text { towns as fears rise for global coro- } \\
\text { navirus spread }\end{array}$ \\
\hline $24 / \mathrm{Feb} / 2020$ & 74.05 & World & Yes & $\begin{array}{l}\text { Coronavirus - Italy locks down } 10 \\
\text { towns as fears rise for global coro- } \\
\text { navirus spread }\end{array}$ & $22 /$ Oct $/ 2019$ & 13.37 & No & No & $\begin{array}{l}\text { Bonds - Argentina's bondholders } \\
\text { braced for steep losses in restruc- } \\
\text { turing }\end{array}$ \\
\hline 13/Dec/2019 & 25.42 & World & Yes & $\begin{array}{l}\text { navirus spread - Lagarde follows } \\
\text { Central Bank } \\
\text { Draghi ECB policy lead but sig- } \\
\text { nals cautious optimism }\end{array}$ & $24 / \mathrm{Feb} / 2020$ & 12.53 & World & Yes & $\begin{array}{l}\text { Coronavirus - Italy locks down } 10 \\
\text { towns as fears rise for global coro- } \\
\text { navirus spread }\end{array}$ \\
\hline $26 /$ Nov $/ 2019$ & 24.37 & China & Yes & $\begin{array}{l}\text { Economic - Takeovers top } \$ 70 \mathrm{bn} \text { in } \\
\text { day of big deals as confidence re- } \\
\text { turns to the US }\end{array}$ & 05/Sep/2019 & 9.50 & No & No & $\begin{array}{l}\text { Economic - Google accused of } \\
\text { covertly passing users' personal } \\
\text { data to advertisers }\end{array}$ \\
\hline $04 / \mathrm{Feb} / 2020$ & 16.55 & World & Yes & $\begin{array}{l}\text { Economic - Goldman nears Ama- } \\
\text { zon loans pact as Main St push } \\
\text { gathers pace }\end{array}$ & 13/Dec/2019 & 7.50 & China & Yes & $\begin{array}{l}\text { Central Bank - Lagarde follows } \\
\text { Draghi ECB policy lead but sig- } \\
\text { nals cautious optimism }\end{array}$ \\
\hline 17/Sep/2019 & 11.72 & No & No & $\begin{array}{l}\text { Oil - Oil price spikes as fears } \\
\text { mount over Saudi supply disrup- } \\
\text { tion }\end{array}$ & $26 / \mathrm{Feb} / 2020$ & 5.43 & World & Yes & $\begin{array}{l}\text { Coronavirus - West steps up moves } \\
\text { to contain virus as investors re- } \\
\text { treat further }\end{array}$ \\
\hline 10/Oct/2019 & 10.13 & No & No & $\begin{array}{l}\text { Economic - OECD unveils taxa- } \\
\text { tion overhaul to squeeze more from } \\
\text { Big Tech }\end{array}$ & 09/Oct/2019 & 4.49 & No & No & $\begin{array}{l}\text { Economic - Blockbuster listing in } \\
\text { doubt after US extends assault on } \\
\text { China tech }\end{array}$ \\
\hline 28/Oct/2019 & 8.76 & No & No & $\begin{array}{l}\text { Political - Germany's annual pay- } \\
\text { ment into EU budget set to double } \\
\text { to } 33 \mathrm{bn}\end{array}$ & 20/Dec/2019 & 4.25 & China & Yes & $\begin{array}{l}\text { Central Bank - UK and US cen- } \\
\text { tral banks probe traders' access to } \\
\text { broadcast feeds }\end{array}$ \\
\hline SSEA \& USD\$ & $\%$ & $\begin{array}{l}\text { COVID-19 } \\
\text { Period }\end{array}$ & $\begin{array}{l}\text { COVID-19 } \\
\text { Influence }\end{array}$ & $\begin{array}{l}\text { FT Main } \\
\text { Headline }\end{array}$ & SSEA \& Corn & $\%$ & $\begin{array}{l}\text { COVID-19 } \\
\text { Period }\end{array}$ & $\begin{array}{l}\text { COVID-19 } \\
\text { Influence }\end{array}$ & $\begin{array}{l}\text { FT Main } \\
\text { Headline }\end{array}$ \\
\hline 31/Mar/2020 & 18.41 & World & Yes & $\begin{array}{l}\text { Coronavirus - Pharma group boost } \\
\text { virus in battle with vaccine and } \\
\text { testing advances }\end{array}$ & $16 /$ Nov/2019 & 576.28 & China & Yes & $\begin{array}{l}\text { Political - Trump attacks Ukraine } \\
\text { witness }\end{array}$ \\
\hline $02 / \mathrm{Mar} / 2020$ & 17.39 & World & Yes & $\begin{array}{l}\text { testing advances } \\
\text { Coronavirus - Italy unveils } 3.6 \mathrm{bn} \\
\text { stimulus as world tallies cost of } \\
\text { coronavirus }\end{array}$ & $05 / \mathrm{Feb} / 2020$ & 164.28 & World & Yes & $\begin{array}{l}\text { Economic - Top US SoftBank fund } \\
\text { executive to quit as bad bets shake } \\
\text { confidence }\end{array}$ \\
\hline $18 / \mathrm{Nov} / 2019$ & 12.64 & China & Yes & $\begin{array}{l}\text { Oil - Aramco pares back fundrais- } \\
\text { ing goal to } \$ 25 \text { bn in latest IPO } \\
\text { hitch }\end{array}$ & $13 / \mathrm{Feb} / 2020$ & 72.76 & World & Yes & $\begin{array}{l}\text { Currency - Patents lay bare scale } \\
\text { of China's ambition to digitise the } \\
\text { renmimbi }\end{array}$ \\
\hline $31 / \mathrm{Jul} / 2019$ & 8.13 & No & No & $\begin{array}{l}\text { Political - Trump rattles equity } \\
\text { markets by lashing out at Beijing } \\
\text { and the Fed }\end{array}$ & $07 / \mathrm{Apr} / 2020$ & 51.09 & World & Yes & $\begin{array}{l}\text { Coronavirus - UK doctors reveal } \\
\text { multi-organ danger posed by coro- } \\
\text { navirus }\end{array}$ \\
\hline 09/Oct/2019 & 7.45 & No & No & $\begin{array}{l}\text { Economic - Blockbuster listing in } \\
\text { doubt after US extends assault on } \\
\text { China tech }\end{array}$ & $24 / \mathrm{Feb} / 2020$ & 26.01 & World & Yes & $\begin{array}{l}\text { Coronavirus - Italy locks down } 10 \\
\text { towns as fears rise for global coro- } \\
\text { navirus spread }\end{array}$ \\
\hline 08/Aug/2019 & 6.65 & No & No & $\begin{array}{l}\text { Central Bank-Aggressive rate } \\
\text { cuts and dismal data accelerate } \\
\text { dash into bonds }\end{array}$ & 03/Dec/2019 & 23.67 & China & Yes & $\begin{array}{l}\text { Polticial - Beijing strikes back at } \\
\text { Trump's support for Hong Kong } \\
\text { protests }\end{array}$ \\
\hline 27/Aug/2019 & 6.23 & No & No & $\begin{array}{l}\text { Political - Trump open to Iran } \\
\text { meeting as Macron seeks to broker } \\
\text { accord }\end{array}$ & 31/Dec/2019 & 15.96 & China & Yes & $\begin{array}{l}\text { Bonds - Bond market barometer } \\
\text { points to investor optimism as } \\
\text { year ends }\end{array}$ \\
\hline $09 / \mathrm{Apr} / 2020$ & 5.10 & World & Yes & $\begin{array}{l}\text { Equities - Wall Street urges cau- } \\
\text { tion as bullish investors run into } \\
\text { recovery bets }\end{array}$ & $03 / \mathrm{Jan} / 2020$ & 14.73 & World & Yes & $\begin{array}{l}\text { Political - Heat rises on Ghosn } \\
\text { as Interpol demands his arrest in } \\
\text { London }\end{array}$ \\
\hline
\end{tabular}

Note: The above table represents the news events that occurred on the date of the largest SSEA skewness spillover. Data is obtained through The Financial Times and LexisNexis. 
Table 11: News events with largest denoted frequency per date of largest SSEB skewness spillover

\begin{tabular}{|c|c|c|c|c|c|c|c|c|c|}
\hline SSEB \& Oil & $\%$ & $\begin{array}{l}\begin{array}{l}\text { COVID-19 } \\
\text { Period }\end{array} \\
\end{array}$ & $\begin{array}{l}\text { COVID-19 } \\
\text { Influence }\end{array}$ & $\begin{array}{l}\text { FT Main } \\
\text { Headline }\end{array}$ & SSEB \& Bitcoin & $\%$ & $\begin{array}{l}\text { COVID-19 } \\
\text { Period }\end{array}$ & $\begin{array}{l}\text { COVID-19 } \\
\text { Influence }\end{array}$ & $\begin{array}{l}\text { FT Main } \\
\text { Headline }\end{array}$ \\
\hline 19/Mar/2020 & 67.47 & World & Yes & $\begin{array}{l}\text { Equities - Fear grips global mar- } \\
\text { kets as faith in interventions runs } \\
\text { out }\end{array}$ & $17 / \mathrm{Jan} / 2020$ & 20.36 & World & Yes & $\begin{array}{l}\text { Oil - Berlin secures } 40 \mathrm{bn} \text { deal with } \\
\text { regions to end use of coal by } 2038\end{array}$ \\
\hline 06/Dec/2019 & 40.57 & China & Yes & $\begin{array}{l}\text { out } \\
\text { Oil - Saudi Aramaco's } \$ 25.6 \mathrm{bn} \\
\text { breaks IPO record despite valua- } \\
\text { tion blow }\end{array}$ & $11 / \mathrm{Mar} / 2020$ & 20.16 & World & Yes & $\begin{array}{l}\text { Coronavirus - Italy widens emer- } \\
\text { gency economy measures as quar- } \\
\text { antine takes toll }\end{array}$ \\
\hline 04/Dec/2019 & 13.92 & China & Yes & $\begin{array}{l}\text { Equities - Investors spooked by } \\
\text { Trump's willingness to delay trade } \\
\text { deal }\end{array}$ & 03/Mar/2020 & 18.72 & World & Yes & $\begin{array}{l}\text { Economic }-O E C D \text { warns virus } \\
\text { threatens to cut global growth in } \\
\text { half }\end{array}$ \\
\hline $01 / \mathrm{Apr} / 2020$ & 7.74 & World & Yes & $\begin{array}{l}\text { Economic - Chinese factories find } \\
\text { new life but European outlook } \\
\text { darkens }\end{array}$ & $10 / \mathrm{Mar} / 2020$ & 14.78 & World & Yes & $\begin{array}{l}\text { Oil - Saudi-Russia oil price war war } \\
\text { sends tremors through global mar- } \\
\text { kets }\end{array}$ \\
\hline 24/Mar/2020 & 6.94 & World & Yes & $\begin{array}{l}\text { Carkens } \\
\text { Central Bank - Federal Reserve's } \\
\text { full firepower fails to arrest slide } \\
\text { in markets }\end{array}$ & $26 / \mathrm{Feb} / 2020$ & 13.96 & World & Yes & $\begin{array}{l}\text { Rets } \\
\text { Coronavirus - West steps up moves } \\
\text { to contain virus as investors re- } \\
\text { treat further }\end{array}$ \\
\hline 16/Dec/2019 & 5.43 & China & Yes & $\begin{array}{l}\text { Political - UN talks on climate } \\
\text { change break up in stalemate }\end{array}$ & 09/Mar/2020 & 13.68 & World & Yes & $\begin{array}{l}\text { Coronavirus - Italy quarantines } \\
\text { vast parts of rich north as virus } \\
\text { cases surge }\end{array}$ \\
\hline $21 / \mathrm{Jan} / 2020$ & 5.33 & World & Yes & $\begin{array}{l}\text { Economic - Downbeat IMF out- } \\
\text { look diverts Davos focus from cli- } \\
\text { mate gaals }\end{array}$ & $12 / \mathrm{Mar} / 2020$ & 13.27 & World & Yes & $\begin{array}{l}\text { Coses surge } \\
\text { Coronavirus - Coronavirus de- } \\
\text { clared a pandemic as fears of eco- } \\
\text { nomic crisis mount }\end{array}$ \\
\hline 06/Dec/2019 & 4.23 & China & Yes & $\begin{array}{l}\text { mate goass Aaudi Aramaco's } \$ 25.6 \mathrm{bn} \\
\text { Oil - Saudi } \\
\text { breaks IPO record despite valua- } \\
\text { tion blow }\end{array}$ & $29 /$ Nov/2019 & 11.98 & China & Yes & $\begin{array}{l}\text { nomitical - Lagande push for cli- } \\
\text { Politic change to spearhead policy } \\
\text { mate change to spear } \\
\text { in ECB review }\end{array}$ \\
\hline SSEB \& USD\$ & $\%$ & $\begin{array}{l}\text { COVID-19 } \\
\text { Period }\end{array}$ & $\begin{array}{l}\text { COVID-19 } \\
\text { Influence }\end{array}$ & $\begin{array}{l}\text { FT Main } \\
\text { Headline }\end{array}$ & SSEB \& Corn & $\%$ & $\begin{array}{l}\text { COVID-19 } \\
\text { Period }\end{array}$ & $\begin{array}{l}\text { COVID-19 } \\
\text { Influence }\end{array}$ & $\begin{array}{l}\text { FT Main } \\
\text { Headline }\end{array}$ \\
\hline 25/Oct/2019 & 18.07 & No & No & $\begin{array}{l}\text { Political - Johnson faces calls to } \\
\text { resign as judges rule parliament's } \\
\text { closure unlawful }\end{array}$ & $08 / \mathrm{Apr} / 2020$ & 475.23 & World & Yes & $\begin{array}{l}\text { Coronavirus - Pandemic will de- } \\
\text { stroy equivalent of } 195 \mathrm{~m} \text { jobs } \\
\text { worldwide, warns UN }\end{array}$ \\
\hline 11/Oct/2019 & 16.06 & No & No & $\begin{array}{l}\text { Political - Trump fires Bolton after } \\
\text { tension on Iran and N Korea boils } \\
\text { over }\end{array}$ & 01/Nov/2019 & 163.03 & China & Yes & $\begin{array}{l}\text { Political - Trump impeachment } \\
\text { hearing to be held in open after } \\
\text { key yote }\end{array}$ \\
\hline $27 / \mathrm{Mar} / 2020$ & 14.56 & World & Yes & $\begin{array}{l}\text { Over } \\
\text { Ecomic - Jobless claims surge to } \\
3.3 \mathrm{~m} \text { record in US }\end{array}$ & $03 / \mathrm{Jan} / 2020$ & 139.60 & World & Yes & $\begin{array}{l}\text { Political - Heat rises on Ghosn } \\
\text { as Interpol demands his arrest in } \\
\text { London }\end{array}$ \\
\hline 02/Dec/2019 & 12.36 & China & Yes & $\begin{array}{l}\text { Political - Merkel's grand coalition } \\
\text { at risk after SPD elects new lead- } \\
\text { ership }\end{array}$ & $24 / \mathrm{Feb} / 2020$ & 10.10 & World & Yes & $\begin{array}{l}\text { Coronavirus - Italy locks down } 10 \\
\text { towns as fears rise for global coro- } \\
\text { navirus spread }\end{array}$ \\
\hline $31 / \mathrm{Mar} / 2020$ & 11.08 & World & Yes & $\begin{array}{l}\text { Coronavirus - Pharma group boost } \\
\text { virus in battle with vaccine and } \\
\text { testing advances }\end{array}$ & $04 / \mathrm{Sep} / 2019$ & 7.33 & No & No & $\begin{array}{l}\text { Economic - US factory sector } \\
\text { dragged down by trade war as } \\
\text { growth fears rise }\end{array}$ \\
\hline 13/Mar/2020 & 9.65 & World & Yes & $\begin{array}{l}\text { Equities - Tramautic day on global } \\
\text { markets spurs central banks to } \\
\text { step up action }\end{array}$ & $21 / \mathrm{Feb} / 2020$ & 6.35 & World & Yes & $\begin{array}{l}\text { Equities - Morgan Stanley joins } \\
\text { rush into retail with } \$ 13 \mathrm{bn} \text { Etrade } \\
\text { swoop }\end{array}$ \\
\hline 28/Aug/2019 & 8.66 & No & No & $\begin{array}{l}\text { Economic - Philip Morris and Al- } \\
\text { tria discuss reuniting to forge } \\
\$ 200 \text { bn giant }\end{array}$ & 31/Oct/2019 & 4.59 & No & No & $\begin{array}{l}\text { Central Bank - Fed cuts rate by } \\
25 \mathrm{bp} \text { but tempers hope of further } \\
\text { easing }\end{array}$ \\
\hline $11 / \mathrm{Mar} / 2020$ & 8.03 & World & Yes & $\begin{array}{l}\text { Coronavirus - Italy widens emer- } \\
\text { gency economy measures as quar- } \\
\text { antine takes toll }\end{array}$ & $13 / \mathrm{Feb} / 2020$ & 3.64 & World & Yes & $\begin{array}{l}\text { Currency - Patents lay bare scale } \\
\text { of China's ambition to digitise the } \\
\text { renmimbi }\end{array}$ \\
\hline
\end{tabular}

Note: The above table represents the news events that occurred on the date of the largest SSEB skewness spillover. Data is obtained through The Financial Times and LexisNexis. 
Table 12: News events with largest denoted frequency per date of largest SSEA kurtosis spillover

\begin{tabular}{|c|c|c|c|c|c|c|c|c|c|}
\hline SSEA \& Oil & $\%$ & $\begin{array}{l}\text { COVID-19 } \\
\text { Period } \\
\end{array}$ & $\begin{array}{l}\text { COVID-19 } \\
\text { Influence }\end{array}$ & $\begin{array}{l}\text { FT Main } \\
\text { Headline }\end{array}$ & SSEA \& Bitcoin & $\%$ & $\begin{array}{l}\text { COVID-19 } \\
\text { Period }\end{array}$ & $\begin{array}{l}\text { COVID-19 } \\
\text { Influence }\end{array}$ & $\begin{array}{l}\text { FT Main } \\
\text { Headline }\end{array}$ \\
\hline $03 / \mathrm{Feb} / 2020$ & 37.97 & World & Yes & $\begin{array}{l}\text { Coronavirus - Beijing deploys } \\
\text { emergency cash to shield markets } \\
\text { from virus fallout }\end{array}$ & $24 / \mathrm{Feb} / 2020$ & 64.53 & World & Yes & $\begin{array}{l}\text { Coronavirus - Italy locks down } 10 \\
\text { towns as fears rise for global coro- } \\
\text { navirus spread }\end{array}$ \\
\hline 02/Sep/2019 & 32.93 & No & No & $\begin{array}{l}\text { from virus fallout } \\
\text { Political - Labour would cost } \\
\text { UK companies } £ 300 \text { bn by shifting } \\
\text { shares to staff }\end{array}$ & $13 /$ Nov/2019 & 58.70 & No & No & $\begin{array}{l}\text { navirus spread } \\
\text { Political - Europe must wrest con- } \\
\text { trol of data from Silicon Valley, } \\
\text { warns Merkel }\end{array}$ \\
\hline 30/Oct/2019 & 31.12 & No & No & $\begin{array}{l}\text { Political - WhatsApp hack used to } \\
\text { snoop on } 100 \text { rights activists and } \\
\text { dissidents }\end{array}$ & $03 / \mathrm{Feb} / 2020$ & 47.86 & World & Yes & $\begin{array}{l}\text { Coronavirus - Beijing deploys } \\
\text { emergency cash to shield markets } \\
\text { from virus fallout }\end{array}$ \\
\hline $24 / \mathrm{Sep} / 2019$ & 27.18 & No & No & $\begin{array}{l}\text { Oil - Oil price spikes as fears } \\
\text { mount over Saudi supply disrup- } \\
\text { tion }\end{array}$ & $26 / \mathrm{Feb} / 2020$ & 26.98 & World & Yes & $\begin{array}{l}\text { Coronavirus - West steps up moves } \\
\text { to contain virus as investors re- } \\
\text { treat further }\end{array}$ \\
\hline 31/Dec/2019 & 5.76 & World & Yes & $\begin{array}{l}\text { Bonds - Bond market barometer } \\
\text { points to investor optimism as } \\
\text { year ends }\end{array}$ & 11/Oct/2019 & 13.73 & No & No & $\begin{array}{l}\text { Political - Varadkar says agree- } \\
\text { ment possible this month as Brexit } \\
\text { mood shifts }\end{array}$ \\
\hline $25 / \mathrm{Sep} / 2019$ & 3.94 & No & No & $\begin{array}{l}\text { Political - Johnson faces calls to } \\
\text { resign as judges rule parliament's } \\
\text { closure unlawful }\end{array}$ & 14/Oct/2019 & 6.11 & No & No & $\begin{array}{l}\text { Political - UK hopes for swift deal } \\
\text { dented as Brexit customs plan baf- } \\
\text { fles EU }\end{array}$ \\
\hline 02/Sep/2019 & 3.64 & No & No & $\begin{array}{l}\text { Political - Labour would cost } \\
\text { UK companies } £ 300 \text { bn by shifting } \\
\text { shares to staff }\end{array}$ & 09/Mar/2020 & 4.80 & World & Yes & $\begin{array}{l}\text { Coronavirus - Italy quarantines } \\
\text { vast parts of rich north as virus } \\
\text { cases surge }\end{array}$ \\
\hline 17/Dec/2019 & 2.83 & China & Yes & $\begin{array}{l}\text { Equities - Johnson's victory fired } \\
\text { UK stocks as Brexit clarity cheers } \\
\text { investors }\end{array}$ & 31/Dec/2019 & 4.61 & World & Yes & $\begin{array}{l}\text { Bonds - Bond market barometer } \\
\text { points to investor optimism as } \\
\text { year ends }\end{array}$ \\
\hline
\end{tabular}

\begin{tabular}{|c|c|c|c|c|c|c|c|c|c|}
\hline SSEA \& USD\$ & $\%$ & $\begin{array}{l}\text { COVID-19 } \\
\text { Period }\end{array}$ & $\begin{array}{l}\text { COVID-19 } \\
\text { Influence }\end{array}$ & $\begin{array}{l}\text { FT Main } \\
\text { Headline }\end{array}$ & SSEA \& Corn & $\%$ & $\begin{array}{l}\text { COVID-19 } \\
\text { Period }\end{array}$ & $\begin{array}{l}\text { COVID-19 } \\
\text { Influence }\end{array}$ & $\begin{array}{l}\text { FT Main } \\
\text { Headline }\end{array}$ \\
\hline $26 / \mathrm{Mar} / 2020$ & 47.60 & World & Yes & $\begin{array}{l}\text { Coronavirus - Poorest nations } \\
\text { need debt relief to tackle virus, say } \\
\text { global lenders }\end{array}$ & $10 / \mathrm{Feb} / 2020$ & 18.03 & World & Yes & $\begin{array}{l}\text { Coronavirus - Shut businesses hi } \\
\text { China push to restart economy } \\
\text { amid killer virus }\end{array}$ \\
\hline $27 / \mathrm{Mar} / 2020$ & 10.67 & World & Yes & $\begin{array}{l}\text { Economic - Jobless claims surge to } \\
3.3 \mathrm{~m} \text { record in US }\end{array}$ & 12/Dec/2019 & 12.80 & China & Yes & $\begin{array}{l}\text { Political - US tightens screws or } \\
\text { Iran with fresh shipping and ai }\end{array}$ \\
\hline 15/Aug/2019 & 5.25 & No & No & $\begin{array}{l}\text { Economic - Bonds sound recession } \\
\text { alarm as China and Germany show } \\
\text { strain }\end{array}$ & 06/Dec/2019 & 8.29 & China & Yes & $\begin{array}{l}\text { sanctions } \\
\text { Oil - Saudi Aramaco's } \$ 25.6 \mathrm{br} \\
\text { breaks IPO record despite valua- } \\
\text { tion blow }\end{array}$ \\
\hline $21 / \mathrm{Feb} / 2020$ & 4.37 & World & Yes & $\begin{array}{l}\text { Equities - Morgan Stanley joins } \\
\text { rush into retail with } \$ 13 \text { bn Etrade } \\
\text { swoop }\end{array}$ & 13/Dec/2019 & 6.75 & China & Yes & $\begin{array}{l}\text { Central Bank - Lagarde follows } \\
\text { Draghi ECB policy lead but sig } \\
\text { nals cautious optimism }\end{array}$ \\
\hline $26 / \mathrm{Mar} / 2020$ & 2.33 & World & Yes & $\begin{array}{l}\text { Coronavirus - Poorest nations } \\
\text { need debt relief to tackle virus, say } \\
\text { global lenders }\end{array}$ & 16/Dec/2019 & 6.28 & China & Yes & $\begin{array}{l}\text { Political - UN talks on climate } \\
\text { change break up in stalemate }\end{array}$ \\
\hline $25 / \mathrm{Nov} / 2019$ & 2.29 & China & Yes & $\begin{array}{l}\text { Economic - LVMH poised to secure } \\
\text { Tiffany as Arnault raises offer to } \\
\$ 16.7 \mathrm{bn}\end{array}$ & 20/Dec/2019 & 4.15 & China & Yes & $\begin{array}{l}\text { Central Bank - UK and US cen } \\
\text { tral banks probe traders' access to } \\
\text { broadcast feeds }\end{array}$ \\
\hline 06/Dec/2019 & 2.15 & China & Yes & $\begin{array}{l}\text { Oil - Saudi Aramaco's } \$ 25.6 \mathrm{bn} \\
\text { breaks IPO record despite valua- } \\
\text { tion blow }\end{array}$ & 18/Dec/2019 & 3.92 & China & Yes & $\begin{array}{l}\text { Economic - JAB sets up } 3 \text { bn coffee } \\
\text { challenge to Nestle by combining } \\
\text { big brands }\end{array}$ \\
\hline $21 / \mathrm{Feb} / 2020$ & 1.36 & World & Yes & $\begin{array}{l}\text { Equities - Morgan Stanley joins } \\
\text { rush into retail with } \$ 13 \text { bn Etrade } \\
\text { swoop }\end{array}$ & 31/Dec/2019 & 3.37 & China & Yes & $\begin{array}{l}\text { Bonds - Bond market barometer } \\
\text { points to investor optimism as } \\
\text { year ends }\end{array}$ \\
\hline
\end{tabular}

Note: The above table represents the news events that occurred on the date of the largest SSEA kurtosis spillover. Data is obtained through The Financial Times and LexisNexis. 
Table 13: News events with largest denoted frequency per date of largest SSEB kurtosis spillover

\begin{tabular}{|c|c|c|c|c|c|c|c|c|c|}
\hline$\overline{\text { SSEB \& Oil }}$ & $\overline{\%}$ & $\begin{array}{l}\text { COVID-19 } \\
\text { Period }\end{array}$ & $\begin{array}{l}\text { COVID-19 } \\
\text { Influence }\end{array}$ & $\begin{array}{c}\text { FT Main } \\
\text { Headline }\end{array}$ & $\overline{\text { SSEB \& Bitcoin }}$ & $\overline{\overline{\%}}$ & $\begin{array}{l}\text { COVID-19 } \\
\text { Period }\end{array}$ & $\begin{array}{l}\text { COVID-19 } \\
\text { Influence }\end{array}$ & $\begin{array}{c}\text { FT Main } \\
\text { Headline }\end{array}$ \\
\hline $14 / \mathrm{Jan} / 2020$ & 28.66 & World & Yes & Political - US poised to lift cur- & $17 / \mathrm{Nov} / 2019$ & 241.92 & China & Yes & $\begin{array}{l}\text { Political - Trump attacks Ukraine } \\
\text { witness }\end{array}$ \\
\hline $07 / \mathrm{Apr} / 2020$ & 22.77 & World & Yes & $\begin{array}{l}\text { Coronavirus - UK doctors reveal } \\
\text { multi-organ danger posed by coro- } \\
\text { navirus }\end{array}$ & $17 / \mathrm{Feb} / 2020$ & 31.24 & World & Yes & $\begin{array}{l}\text { Witness } \\
\text { Equities - Vision Fund chie } \\
\text { pushes equities vehicle after } \\
\text { SoftBank stumbles }\end{array}$ \\
\hline $08 / \mathrm{Apr} / 2020$ & 5.47 & World & Yes & $\begin{array}{l}\text { Coronavirus - Pandemic will de- } \\
\text { stroy equivalent of } 195 \mathrm{~m} \text { jobs } \\
\text { worldwide, warns UN }\end{array}$ & $31 / \mathrm{Dec} / 2019$ & 11.44 & World & Yes & $\begin{array}{l}\text { Bonds - Bond market barometer } \\
\text { points to investor optimism as } \\
\text { year ends }\end{array}$ \\
\hline $02 / \mathrm{Apr} / 2020$ & 4.76 & World & Yes & $\begin{array}{l}\text { Economic - Default warnings spark } \\
\text { fears of emerging market debt } \\
\text { crunch }\end{array}$ & $18 / \mathrm{Nov} / 2019$ & 10.98 & China & Yes & $\begin{array}{l}\text { Oil - Aramco pares back fundrais- } \\
\text { ing goal to } \$ 25 \text { bn in latest IPO } \\
\text { hitch }\end{array}$ \\
\hline $03 / \mathrm{Apr} / 2020$ & 3.70 & World & Yes & $\begin{array}{l}\text { Economic - Jobless claims surge in } \\
\text { Europe and US as global economy } \\
\text { stifles }\end{array}$ & $02 / \mathrm{Apr} / 2020$ & 6.76 & World & Yes & $\begin{array}{l}\text { Economic - Default warnings spark } \\
\text { fears of emerging market debt } \\
\text { crunch }\end{array}$ \\
\hline $17 / \mathrm{Jan} / 2020$ & 3.24 & World & Yes & $\begin{array}{l}\text { Oil - Berlin secures } 40 \mathrm{bn} \text { deal with } \\
\text { regions to end use of coal by } 2038\end{array}$ & $04 / \mathrm{Feb} / 2020$ & 4.83 & World & Yes & $\begin{array}{l}\text { Economic - Goldman nears Ama- } \\
\text { zon loans pact as Main St push }\end{array}$ \\
\hline $15 / \mathrm{Jan} / 2020$ & 3.07 & World & Yes & $\begin{array}{l}\text { Political - UK, France and Ger- } \\
\text { many raise heat on Iran over nu- } \\
\text { clear breach }\end{array}$ & $09 / \mathrm{Mar} / 2020$ & 4.43 & World & Yes & $\begin{array}{l}\text { Coronavirus - Italy quarantines } \\
\text { vast parts of rich north as virus } \\
\text { cases surge }\end{array}$ \\
\hline $29 / \mathrm{Jul} / 2019$ & 2.22 & No & No & $\begin{array}{l}\text { Economic - Carmakers face tough } \\
\text { choice on China as vehicle sales } \\
\text { plummet }\end{array}$ & 05/Dec/2019 & 4.34 & China & Yes & $\begin{array}{l}\text { Political-Germany sees Kremlin's } \\
\text { hand in Berlin murder of Chechen } \\
\text { rebel }\end{array}$ \\
\hline SSEB \& USD\$ & $\%$ & $\begin{array}{l}\text { COVID-19 } \\
\text { Period }\end{array}$ & $\begin{array}{l}\text { COVID-19 } \\
\text { Influence } \\
\end{array}$ & $\begin{array}{l}\text { FT Main } \\
\text { Headline }\end{array}$ & SSEB \& Corn & $\%$ & $\begin{array}{l}\text { COVID-19 } \\
\text { Period }\end{array}$ & $\begin{array}{l}\text { COVID-19 } \\
\text { Influence } \\
\end{array}$ & $\begin{array}{l}\text { FT Main } \\
\text { Headline }\end{array}$ \\
\hline $21 / \mathrm{Jan} / 2020$ & 59.51 & World & Yes & $\begin{array}{l}\text { Economic - Downbeat IMF out- } \\
\text { look diverts Davos focus from cli- } \\
\text { mate goals }\end{array}$ & $10 / \mathrm{Feb} / 2020$ & 18.03 & World & Yes & $\begin{array}{l}\text { Coronavirus - Shut businesses hit } \\
\text { China push to restart economy } \\
\text { amid killer virus }\end{array}$ \\
\hline 18/Nov/2019 & 31.71 & China & Yes & $\begin{array}{l}\text { Oil - Aramco pares back fundrais- } \\
\text { ing goal to } \$ 25 \mathrm{bn} \text { in latest IPO } \\
\text { hitch }\end{array}$ & 12/Dec/2019 & 12.80 & China & Yes & $\begin{array}{l}\text { Political - US tightens screws on } \\
\text { Iran with fresh shipping and air } \\
\text { sanctions }\end{array}$ \\
\hline 19/Nov/2019 & 5.26 & China & Yes & $\begin{array}{l}\text { Political - Police lay siege to uni- } \\
\text { versity students }\end{array}$ & $06 / \mathrm{Dec} / 2019$ & 8.29 & China & Yes & $\begin{array}{l}\text { Oil - Saudi Aramaco's } \$ 25.6 \mathrm{bn} \\
\text { breaks IPO record despite valua- } \\
\text { tion blow }\end{array}$ \\
\hline 06/Dec/2019 & 4.14 & China & Yes & $\begin{array}{l}\text { Oil - Saudi Aramaco's } \$ 25.6 \mathrm{bn} \\
\text { breaks IPO record despite valua- } \\
\text { tion blow }\end{array}$ & 13/Dec/2019 & 6.75 & China & Yes & $\begin{array}{l}\text { Central Bank - Lagarde follows } \\
\text { Draghi ECB policy lead but sig. } \\
\text { nals cautious optimism }\end{array}$ \\
\hline $17 / \mathrm{Mar} / 2020$ & 2.81 & World & Yes & $\begin{array}{l}\text { Equities - Global stocks take fresh } \\
\text { pummelling as Fed action fails to } \\
\text { calm investors }\end{array}$ & $12 / \mathrm{Dec} / 2019$ & 6.28 & China & Yes & $\begin{array}{l}\text { Political - US tightens screws on on } \\
\text { Iran with fresh shipping and air } \\
\text { sanctions }\end{array}$ \\
\hline $10 / \mathrm{Apr} / 2020$ & 2.79 & World & Yes & $\begin{array}{l}\text { Oil - G } 20 \text { and US throw weight be- } \\
\text { hind biggest oil production agree- } \\
\text { ment }\end{array}$ & 20/Dec/2019 & 4.15 & China & Yes & $\begin{array}{l}\text { Central Bank - UK and US cen- } \\
\text { tral banks probe traders' access to } \\
\text { broadcast feeds }\end{array}$ \\
\hline $11 / \mathrm{Sep} / 2019$ & 2.66 & No & No & $\begin{array}{l}\text { Political - Trump fires Bolton after } \\
\text { tension on Iran and N Korea boils } \\
\text { over }\end{array}$ & 18/Dec/2019 & 3.92 & China & Yes & $\begin{array}{l}\text { Economic - JAB sets up } 3 \text { bn coffee } \\
\text { challenge to Nestle by combining } \\
\text { big brands }\end{array}$ \\
\hline $16 / \mathrm{Sep} / 2019$ & 2.53 & No & No & $\begin{array}{l}\text { Oil - Saudis seek to reassure mar- } \\
\text { kets as attack halves oil produc- } \\
\text { tion }\end{array}$ & 31/Dec/2019 & 3.37 & World & Yes & $\begin{array}{l}\text { Bonds - Bond market barometer } \\
\text { points to investor optimism as } \\
\text { year ends }\end{array}$ \\
\hline
\end{tabular}
Note: The above table represents the news events that occurred on the date of the largest SSEB kurtosis spillover. Data is obtained through The Financial 
Table 14: Logarithmic ratios of static information share measures at 30-min intervals, Ratios of information share measures between SSEA index and other assets

\begin{tabular}{|c|c|c|c|c|}
\hline & Oil & Bitcoin & US dollar & Corn \\
\hline \multicolumn{5}{|c|}{ P1: July 1, 2019 - November 16, 2019} \\
\hline CS ratio & 0.193 & 5.436 & 0.724 & -1.172 \\
\hline IS ratio & -2.085 & 5.276 & 3.434 & -1.418 \\
\hline ILS ratio & -4.557 & -0.319 & 5.421 & -0.493 \\
\hline \multicolumn{5}{|c|}{ P2: November 17, 2019 - December 30, 2019} \\
\hline CS ratio & 1.52 & -2.337 & -2.18 & 1.173 \\
\hline IS ratio & 1.1037 & -6.583 & -1.829 & 2.234 \\
\hline ILS ratio & -0.832 & -8.491 & 0.702 & 2.123 \\
\hline \multicolumn{5}{|c|}{ P3: December 31, 2019 - April 10, 2020 } \\
\hline CS ratio & 0.891 & 1.233 & 2.238 & -1.393 \\
\hline IS ratio & 0.234 & -0.768 & 7.006 & -1.224 \\
\hline ILS ratio & -1.314 & -4.003 & 9.537 & 0.338 \\
\hline \multicolumn{5}{|c|}{ Changes in ratios between sub-periods } \\
\hline \multicolumn{5}{|c|}{ Ratios in P2 minus Ratios in P1 } \\
\hline CS ratio & 1.327 & -7.773 & -2.904 & 2.345 \\
\hline IS ratio & 3.189 & -11.859 & -5.263 & 3.652 \\
\hline ILS ratio & 3.725 & -8.172 & -4.719 & 2.616 \\
\hline \multicolumn{5}{|c|}{ Ratios in P3 minus Ratios in P2 } \\
\hline CS ratio & -0.629 & 3.57 & 4.418 & -2.566 \\
\hline IS ratio & -0.87 & 5.815 & 8.835 & -3.458 \\
\hline ILS ratio & -0.482 & 4.488 & 8.835 & -1.785 \\
\hline
\end{tabular}

Note: Logarithmic ratios of information share measures are calculated as the natural logarithms of ratios of static information share measures of Shanghai Stock Exchange A and B-share indices over the other five assets. CS, component share; IS, information share; ILS, information leadership share. Static information share measures are calculated based on estimates of the VECM at each Sub-period. SSEA index is the Shanghai Stock Exchange A-share index; SSEB index is the Shanghai Stock Exchange B-share index. Diff. represents the result of subtraction in ratios. 
Table 15: Logarithmic ratios of static information share measures at 30-min intervals, Ratios of information share measures between SSEB index and other assets

\begin{tabular}{|c|c|c|c|c|}
\hline & Oil & Bitcoin & US dollar & Corn \\
\hline \multicolumn{5}{|c|}{ P1: July 1, 2019 - November 16, 2019} \\
\hline $\mathrm{CS}$ ratio & -0.021 & 2.446 & -0.625 & -0.338 \\
\hline IS ratio & -2.701 & 0.828 & 0.613 & -0.11 \\
\hline ILS ratio & -5.361 & -3.235 & 2.476 & 0.457 \\
\hline \multicolumn{5}{|c|}{ P2: November 17, 2019 - December 30, 2019} \\
\hline CS ratio & -1.056 & -0.993 & -1.748 & -1.446 \\
\hline IS ratio & -2.629 & -4.461 & -0.609 & -1.142 \\
\hline ILS ratio & -3.146 & -6.936 & 2.277 & 0.608 \\
\hline \multicolumn{5}{|c|}{ P3: December 31, 2019 - April 10, 2020 } \\
\hline CS ratio & 0.682 & 1.396 & -0.236 & 0.112 \\
\hline IS ratio & -0.022 & -0.476 & 2.097 & 1.41 \\
\hline ILS ratio & -1.408 & -3.744 & 4.667 & 2.594 \\
\hline \multicolumn{5}{|c|}{ Changes in ratios between sub-periods } \\
\hline \multicolumn{5}{|c|}{ Ratios in P2 minus Ratios in P1 } \\
\hline CS ratio & -1.035 & -3.439 & -1.123 & -1.108 \\
\hline IS ratio & 0.072 & -5.289 & -1.222 & -1.032 \\
\hline ILS ratio & 2.215 & -3.701 & -0.199 & 0.151 \\
\hline \multicolumn{5}{|c|}{ Ratios in P3 minus Ratios in P2 } \\
\hline CS ratio & 1.738 & 2.389 & 1.512 & 1.558 \\
\hline IS ratio & 2.607 & 3.985 & 2.706 & 2.552 \\
\hline ILS ratio & 1.738 & 3.192 & 2.39 & 1.986 \\
\hline
\end{tabular}

Note: Logarithmic ratios of information share measures are calculated as the natural logarithms of ratios of static information share measures of Shanghai Stock Exchange A and B-share indices over the other five assets. CS, component share; IS, information share; ILS, information leadership share. Static information share measures are calculated based on estimates of the VECM at each Sub-period. SSEA index is the Shanghai Stock Exchange A-share index; SSEB index is the Shanghai Stock Exchange B-share index. Diff. represents the result of subtraction in ratios. 
Table 16: Static net spillovers of higher moments at 30-min intervals, Net spillovers from SSEA index to other assets

\begin{tabular}{|c|c|c|c|c|c|}
\hline & & Oil & Bitcoin & US dollar & Corn \\
\hline \multicolumn{6}{|c|}{ P1: July 1, 2019 - November 16, 2019} \\
\hline \multirow[t]{2}{*}{ Volatility spillover } & & $14.306^{* * *}$ & $1.936^{* * *}$ & $-0.827 * * *$ & $0.081^{*}$ \\
\hline & Wald-test & 214.426 & 35.978 & 39.278 & 2.795 \\
\hline \multirow[t]{2}{*}{ Skewness spillover } & & $0.186^{*}$ & $-0.414^{* * *}$ & -0.257 & 0.092 \\
\hline & Wald-test & 3.342 & 57.233 & 2.191 & 0.104 \\
\hline \multirow[t]{2}{*}{ Kurtosis spillover } & & $1.690^{* * *}$ & $0.012^{*}$ & -0.005 & 0.098 \\
\hline & Wald-test & 363.654 & 3.751 & 0.076 & 2.527 \\
\hline \multicolumn{6}{|c|}{ P2: November 17, 2019 - December 30, 2019} \\
\hline \multirow[t]{2}{*}{ Volatility spillover } & & $9.203^{* * *}$ & $3.998 * * *$ & -0.127 & $-0.315^{* *}$ \\
\hline & Wald-test & 49.564 & 34.074 & 0.585 & 4.408 \\
\hline \multirow[t]{2}{*}{ Skewness spillover } & & 0.342 & 0.13 & $-2.079 * * *$ & 0.727 \\
\hline & Wald-test & 2.289 & 2.099 & 38.632 & 1.424 \\
\hline \multirow[t]{2}{*}{ Kurtosis spillover } & & $1.960^{* * *}$ & -0.008 & -0.004 & $-0.242^{* *}$ \\
\hline & Wald-test & 365.581 & 0.934 & 0.039 & 6.364 \\
\hline \multicolumn{6}{|c|}{ P3: December 31, 2019 - April 10, 2020} \\
\hline \multirow[t]{2}{*}{ Volatility spillover } & & $4.840^{* * *}$ & 0.143 & $-2.741 * * *$ & $0.212^{* * *}$ \\
\hline & Wald-test & 405.354 & 2.258 & 162.86 & 135.958 \\
\hline \multirow[t]{2}{*}{ Skewness spillover } & & -0.079 & $0.268 * *$ & 0.109 & 0.18 \\
\hline & Wald-test & 0.528 & 4.525 & 0.099 & 0.293 \\
\hline \multirow[t]{2}{*}{ Kurtosis spillover } & & $0.847^{* * *}$ & $-0.022 * *$ & -0.013 & $0.360 * * *$ \\
\hline & Wald-test & 239.22 & 6.044 & 0.346 & 42.105 \\
\hline \multicolumn{6}{|c|}{ Changes in spillovers between sub-periods } \\
\hline \multicolumn{6}{|c|}{ Spillovers in P2 minus Spillovers in P1 } \\
\hline \multirow[t]{2}{*}{ Volatility spillover } & Diff. & $-5.103^{* * *}$ & $2.063^{* * *}$ & $0.700^{* * *}$ & $-0.395^{* *}$ \\
\hline & Wald-test & 77.866 & 18.752 & 37.049 & 5.161 \\
\hline \multirow[t]{2}{*}{ Skewness spillover } & Diff. & 0.156 & $0.544^{* * *}$ & $-1.822 * * *$ & 0.634 \\
\hline & Wald-test & 0.397 & 31.3 & 16.481 & 0.91 \\
\hline \multirow[t]{2}{*}{ Kurtosis spillover } & Diff. & $0.270^{* * *}$ & $-0.020^{* * *}$ & 0.001 & $-0.340^{* *}$ \\
\hline & Wald-test & 226.612 & 37.133 & 0.001 & 4.687 \\
\hline \multicolumn{6}{|c|}{ Spillovers in P3 minus Spillovers in P2 } \\
\hline \multirow[t]{2}{*}{ Volatility spillover } & Diff. & $-4.363^{* * *}$ & $-3.855^{* * *}$ & $-2.615^{* * *}$ & $0.526^{* * *}$ \\
\hline & Wald-test & 15.357 & 33.54 & 137.332 & 11.177 \\
\hline \multirow[t]{2}{*}{ Skewness spillover } & Diff. & $-0.421^{*}$ & 0.138 & $2.188^{* * *}$ & -0.546 \\
\hline & Wald-test & 2.808 & 0.812 & 14.132 & 0.618 \\
\hline \multirow[t]{2}{*}{ Kurtosis spillover } & Diff. & $-1.113^{* * *}$ & $-0.014^{* * *}$ & $-0.010^{*}$ & $0.603^{* * *}$ \\
\hline & Wald-test & 498.086 & 110.862 & 3.056 & 16.327 \\
\hline
\end{tabular}

Note: Net spillovers from the Shanghai Stock Exchange A- and B-share indices to other assets are calculated as the differences between absolute values of spillovers from A- and B-share indices to other assets and absolute values of spillovers of the other way around. Static spillovers are derived from estimates of an extended VAR(1) model. Time varying higher moments are obtained via a two-state regime switching model. SSEA index is the Shanghai Stock Exchange A-share index; SSEB index is the Shanghai Stock Exchange B-share index. Diff. represents the result of subtraction in spillovers. Wald-test denotes the Wald test statistic for the hypothesis testing of zero spillovers or differences. E stands for scientific notation. $* * *, * *$ and $*$ denote significance at the $1 \%, 5 \%$ and $10 \%$ levels. 
Table 17: Static net spillovers of higher moments at 30-min intervals, Net spillovers from SSEB index to other assets

\begin{tabular}{|c|c|c|c|c|c|}
\hline & & Oil & Bitcoin & US dollar & Corn \\
\hline \multicolumn{6}{|c|}{ P1: July 1, 2019 - November 16, 2019} \\
\hline \multirow[t]{2}{*}{ Volatility spillover } & & $1.541^{* * *}$ & $4.584^{* * *}$ & $-0.160^{* *}$ & $0.425^{* * *}$ \\
\hline & Wald-test & 23.992 & 31.392 & 6.177 & 64.652 \\
\hline \multirow[t]{2}{*}{ Skewness spillover } & & $-4.420 * * *$ & $-1.050 * * *$ & $0.123^{* *}$ & 0.065 \\
\hline & Wald-test & 388.58 & 114.975 & 4.65 & 0.181 \\
\hline \multirow[t]{2}{*}{ Kurtosis spillover } & & $0.112^{* * *}$ & $-0.023^{* * *}$ & -0.004 & 0.065 \\
\hline & Wald-test & 89.843 & 71.805 & 0.485 & 0.181 \\
\hline \multicolumn{6}{|c|}{ P2: November 17, 2019 - December 30, 2019} \\
\hline \multirow[t]{2}{*}{ Volatility spillover } & & 0.037 & $3.337 * * *$ & $-0.674^{* * *}$ & -0.121 \\
\hline & Wald-test & 0.115 & 35.338 & 16.117 & 1.337 \\
\hline \multirow[t]{2}{*}{ Skewness spillover } & & $-3.018^{* * *}$ & $-0.691 * * *$ & $0.124^{*}$ & 0.078 \\
\hline & Wald-test & 101.339 & 37.774 & 3.065 & 0.193 \\
\hline \multirow[t]{2}{*}{ Kurtosis spillover } & & 0.016 & $-0.134^{* * *}$ & -0.005 & 0.078 \\
\hline & Wald-test & 2.129 & 980.367 & 1.523 & 0.193 \\
\hline \multicolumn{6}{|c|}{ P3: December 31, 2019 - April 10, 2020 } \\
\hline \multirow[t]{2}{*}{ Volatility spillover } & & $0.439^{* * *}$ & $0.901^{* * *}$ & $-0.894^{* * *}$ & 0.035 \\
\hline & Wald-test & 39.664 & 14.088 & 24.962 & 2.087 \\
\hline \multirow[t]{2}{*}{ Skewness spillover } & & $-1.998^{* * *}$ & -0.027 & $-0.207 * * *$ & 0.255 \\
\hline & Wald-test & 16.223 & 0.037 & 7.253 & 0.98 \\
\hline \multirow{2}{*}{ Kurtosis spillover } & & $0.230 * * *$ & 0.055 & $-0.018^{* * *}$ & 0.255 \\
\hline & Wald-test & 246.946 & $271.941^{* * *}$ & 24.566 & 0.98 \\
\hline \multicolumn{6}{|c|}{ Changes in spillovers between sub-periods } \\
\hline \multicolumn{6}{|c|}{ Spillovers in P2 minus Spillovers in P1 } \\
\hline \multirow[t]{2}{*}{ Volatility spillover } & Diff. & $-1.504^{* * *}$ & $-1.247 * * *$ & $-0.513^{* * *}$ & $-0.546^{* * *}$ \\
\hline & Wald-test & 44.257 & 8.458 & 18.72 & 43.766 \\
\hline \multirow[t]{2}{*}{ Skewness spillover } & Diff. & $1.402^{* * *}$ & $0.359 * * *$ & 0.001 & 0.013 \\
\hline & Wald-test & 21.45 & 6.84 & $8.16 \mathrm{E}-05$ & 0.012 \\
\hline \multirow[t]{2}{*}{ Kurtosis spillover } & Diff. & $-0.096^{* * *}$ & $-0.111^{* * *}$ & -0.001 & 0.013 \\
\hline & Wald-test & 555.434 & 2422.113 & 0.44 & 0.012 \\
\hline \multicolumn{6}{|c|}{ Spillovers in P3 minus Spillovers in P2 } \\
\hline \multirow[t]{2}{*}{ Volatility spillover } & Diff. & $0.402^{* * *}$ & $-2.436 * * *$ & $-0.221 * * *$ & 0.157 \\
\hline & Wald-test & 33.461 & 32.365 & 7.835 & 2.295 \\
\hline \multirow[t]{2}{*}{ Skewness spillover } & Diff. & $1.020 * *$ & $0.664^{* * *}$ & $-0.330 * * *$ & 0.177 \\
\hline & Wald-test & 4.309 & 12.593 & 12.021 & 0.991 \\
\hline \multirow[t]{2}{*}{ Kurtosis spillover } & Diff. & $0.213^{* * *}$ & $0.189^{* * *}$ & $-0.013^{* *}$ & 0.177 \\
\hline & Wald-test & 466.64 & 2132.291 & 3.853 & 0.991 \\
\hline
\end{tabular}

Note: Net spillovers from the Shanghai Stock Exchange A- and B-share indices to other assets are calculated as the differences between absolute values of spillovers from A- and B-share indices to other assets and absolute values of spillovers of the other way around. Static spillovers are derived from estimates of an extended VAR(1) model. Time varying higher moments are obtained via a two-state regime switching model. SSEA index is the Shanghai Stock Exchange A-share index; SSEB index is the Shanghai Stock Exchange B-share index. Diff. represents the result of subtraction in spillovers. Wald-test denotes the Wald test statistic for the hypothesis testing of zero spillovers or differences. E stands for scientific notation. $* * *, * *$ and $*$ denote significance at the $1 \%, 5 \%$ and $10 \%$ levels. 